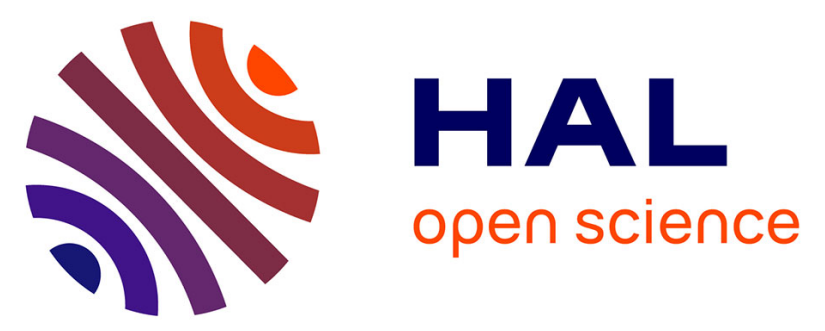

\title{
Dibenzofuran Derivatives Inspired from Cercosporamide as Dual Inhibitors of Pim and CLK1 Kinases
}

\author{
Viet Hung Dao, Isabelle Ourliac-Garnier, Cédric Logé, Florence Mccarthy, \\ Stéphane Bach, Teresinha Gonçalves da Silva, Caroline Denevault-Sabourin, \\ Jérôme Thiéfaine, Blandine Baratte, Thomas Robert, et al.
}

\section{To cite this version:}

Viet Hung Dao, Isabelle Ourliac-Garnier, Cédric Logé, Florence Mccarthy, Stéphane Bach, et al.. Dibenzofuran Derivatives Inspired from Cercosporamide as Dual Inhibitors of Pim and CLK1 Kinases. Molecules, 2021, 26 (21), pp.6572. 10.3390/molecules26216572 . hal-03428747

\section{HAL Id: hal-03428747 https://hal.science/hal-03428747}

Submitted on 15 Nov 2021

HAL is a multi-disciplinary open access archive for the deposit and dissemination of scientific research documents, whether they are published or not. The documents may come from teaching and research institutions in France or abroad, or from public or private research centers.
L'archive ouverte pluridisciplinaire HAL, est destinée au dépôt et à la diffusion de documents scientifiques de niveau recherche, publiés ou non, émanant des établissements d'enseignement et de recherche français ou étrangers, des laboratoires publics ou privés. 


\title{
Dibenzofuran Derivatives Inspired from Cercosporamide as Dual Inhibitors of Pim and CLK1 Kinases
}

\author{
Viet Hung Dao ${ }^{1,+(\mathbb{D})}$, Isabelle Ourliac-Garnier ${ }^{1} \mathbb{D}$, Cédric Logé ${ }^{1} \mathbb{D}$, Florence O. McCarthy ${ }^{2} \mathbb{D}$, Stéphane Bach $^{3,4,5} \mathbf{D}^{\mathbb{D}}$, \\ Teresinha Gonçalves da Silva ${ }^{6}$ D , Caroline Denevault-Sabourin ${ }^{7}$ (D), Jérôme Thiéfaine ${ }^{1}$, Blandine Baratte ${ }^{3,4}$ (D), \\ Thomas Robert $^{3,4}$, Fabrice Gouilleux ${ }^{8}\left(\mathbb{D}\right.$, Marie Brachet-Botineau ${ }^{8}$, Marc-Antoine Bazin ${ }^{1}(\mathbb{D}$ \\ and Pascal Marchand 1,*iD
}

\section{check for} updates

Citation: Dao, V.H.; Ourliac-Garnier I.; Logé, C.; McCarthy, F.O.; Bach, S.; da Silva, T.G.; Denevault-Sabourin,

C.; Thiéfaine, J.; Baratte, B.; Robert, T.; et al. Dibenzofuran Derivatives Inspired from Cercosporamide as Dual Inhibitors of Pim and CLK1 Kinases. Molecules 2021, 26, 6572. https://doi.org/10.3390/ molecules 26216572

Academic Editor: Brullo Chiara

Received: 4 October 2021

Accepted: 26 October 2021

Published: 30 October 202

Publisher's Note: MDPI stays neutral with regard to jurisdictional claims in published maps and institutional affiliations.

Copyright: (C) 2021 by the authors. Licensee MDPI, Basel, Switzerland. This article is an open access article distributed under the terms and conditions of the Creative Commons Attribution (CC BY) license (https:// creativecommons.org/licenses/by/ $4.0 /)$.
1 Cibles et Médicaments des Infections et du Cancer, IICiMed, EA 1155, Université de Nantes, 44000 Nantes, France; daoviethung@live.com (V.H.D.); isabelle.ourliac@univ-nantes.fr (I.O.-G.); cedric.loge@univ-nantes.fr (C.L.); jerome.thiefaine@univ-nantes.fr (J.T.); marc-antoine.bazin@univ-nantes.fr (M.-A.B.)

2 School of Chemistry, Analytical and Biological Chemistry Research Facility, University College Cork, Western Road, T12 K8AF Cork, Ireland; f.mccarthy@ucc.ie

3 Sorbonne Université, CNRS, UMR8227, Integrative Biology of Marine Models Laboratory (LBI2M), Station Biologique de Roscoff, 29680 Roscoff, France; bach@sb-roscoff.fr (S.B.); baratte@sb-roscoff.fr (B.B.); thomas.robert@sb-roscoff.fr (T.R.)

4 Sorbonne Université, CNRS, FR2424, Plateforme de Criblage KISSf (Kinase Inhibitor Specialized Screening Facility), Station Biologique de Roscoff, 29680 Roscoff, France

5 Centre of Excellence for Pharmaceutical Sciences, North-West University, Private Bag X6001, Potchefstroom 2520, South Africa

6 Departamento de Antibióticos, Universidade Federal de Pernambuco, Recife 50670-901, PE, Brazil; teresinha.goncalves@ufpe.br

7 EA GICC-ERL 7001 CNRS, Team IMT, University of Tours, 37200 Tours, France; caroline.denevault@univ-tours.fr

8 CNRS ERL7001 LNOx «Leukemic Niche and redOx Metabolism», EA GICC, University of Tours, 37000 Tours, France; fabrice.gouilleux@univ-tours.fr (F.G.); marie.brachet.botineau@gmail.com (M.B.-B.)

* Correspondence: pascal.marchand@univ-nantes.fr; Tel.: +33-253-009-155

† Current address: Phu Tho College of Medicine and Pharmacy, Viet Tri, Phu Tho 290000, Vietnam.

Abstract: Pim kinases (proviral integration site for Moloney murine leukemia virus kinases) are overexpressed in various types of hematological malignancies and solid carcinomas, and promote cell proliferation and survival. Thus, Pim kinases are validated as targets for antitumor therapy. In this context, our combined efforts in natural product-inspired library generation and screening furnished very promising dibenzo[ $[b, d]$ furan derivatives derived from cercosporamide. Among them, lead compound 44 was highlighted as a potent Pim-1/2 kinases inhibitor with an additional nanomolar $\mathrm{IC}_{50}$ value against CLK1 (cdc2-like kinases 1) and displayed a low micromolar anticancer potency towards the MV4-11 (AML) cell line, expressing high endogenous levels of Pim-1/2 kinases. The design, synthesis, structure-activity relationship, and docking studies are reported herein and supported by enzyme, cellular assays, and Galleria mellonella larvae testing for acute toxicity.

Keywords: cercosporamide; dibenzo[ $b, d]$ furan; Pim kinases; CLK1 kinase; kinase inhibitors; anticancer agents

\section{Introduction}

Cercosporamide is a natural product isolated from pathogen fungus Cercosporidium henningsii, commonly found in extensively cultivated plants (Manihot esculenta) for domestic consumption of tapioca in tropical and subtropical regions worldwide [1]. Moreover, this substance can be found in cultures of Phoma fungi isolated from Guinea plant Saurauia scaberrinae [2] and Chinese medicinal plant Arisaema erubescensor [3], or can be produced by fungi of the genus Lachnum and Pseudaegerita [4]. As the main structural features, 
(-)-cercosporamide exhibits a tricyclic unit containing an asymmetric quaternary carbon with absolute configuration $S$ at position 9a (Figure 1). Additionally, cercosporamide presents two phenol groups at the position 1 and 3, a hydroxyl group (position 7), and a carboxamide group (position 4). An acetyl group (position 8) and an oxo group (position 9) are also attached to the dihydrodibenzofuran portion. Sugawara and co-workers [1] first identified this phytotoxin in 1991 from African strains of $C$. henningsii. In this work, cercosporamide was characterized as a tautomeric mixture (both in solution and in the solid state) through single-crystal X-ray diffraction, 2-D long-range ${ }^{1} \mathrm{H}_{-}{ }^{13} \mathrm{C}$, and COSY NMR techniques.

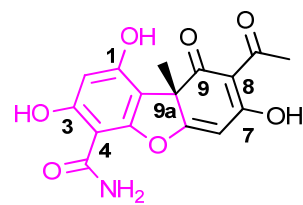

(-)-Cercosporamide

Pim-1 IC $\mathrm{I}_{50}=732 \mathrm{nM}$

Pim-2 $\mathrm{IC}_{50}=2210 \mathrm{nM}$

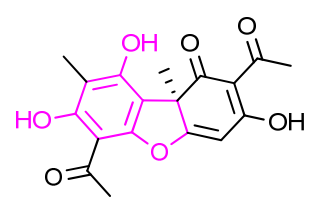

(+)-Usnic acid

Pim-1 $\mathrm{IC}_{50}=210 \mathrm{nM}$

Pim-2 $\mathrm{IC}_{50}=580 \mathrm{nM}$

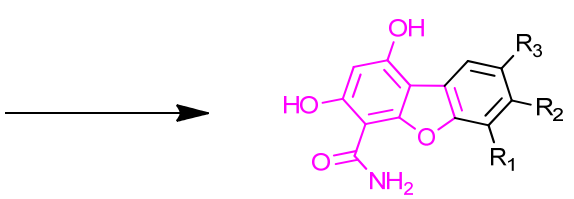

Dibenzo[b,d]furans

$\mathrm{R}_{1}=\mathrm{H}, \mathrm{NO}_{2}, \mathrm{NH}_{2}$

$\mathrm{R}_{2}=\mathrm{H}, \mathrm{OH}$

$\mathrm{R}_{3}=\mathrm{H}, \mathrm{COCH}_{3}, \mathrm{~F}, \mathrm{CF}_{3}$

Figure 1. Drug design of the 1,3-dihydroxydibenzo[ $b, d]$ furan-4-carboxamide scaffold-based derivatives.

Since the discovery of cercosporamide, important findings concerning its biological activities have been reported. In 2004, Sussman et al. [5] reported cercosporamide as a potent selective inhibitor of Candida albicans CaPkc1 (PKC-like 1 kinase), which is central to fungal cell wall integrity and was validated as a fungal drug target in cases where drug resistance is evident. In addition, according to the literature [6], cercosporamide was shown to be a potent $\mathrm{ATP}$-competitive $\mathrm{CaPkc1}$ inhibitor with $\mathrm{IC}_{50}=44 \mathrm{nM}$. In the last decade, nanomolar range inhibition of MAPK-interacting kinases (Mnk1/2) by cercosporamide has been shown to be an efficient alternative to block the activation of the translation initiation factor $4 \mathrm{E}$ (eIF4E) pathway and consequently to prevent tumor growth and progression $[7,8]$. In this way, activity against lung cancer [8], acute myeloid leukemia [9], and hepatocellular carcinoma [10] have been achieved by employing cercosporamide as an Mnk1/2 kinase inhibitor. In addition, inhibition of Mnk pathways by cercosporamide enhanced glioblastoma cell response to chemotherapy and radionuclide therapy [11]. Recent results in the zebrafish model, through the inhibition of bone morphogenetic protein receptor (BMPR) type I kinase, suggest that cercosporamide represents a potential therapeutic strategy to combat diseases with overactive BMPR signaling, including the rare genetic disorder fibrodysplasia ossificans progressiva (FOP) and the rare childhood brainstem tumor diffuse intrinsic pontine glioma (DIPG) [12].

In addition, cercosporamide-inspired synthetic compounds have also been reported. Furukawa et al. described the preparation of novel antihyperglycemic agents from cercosporamide [13]. In this work, a potent plasma glucose-lowering effect was observed in hyperglycemic KK/Ta mice. The same group completed the previous work by designing cercosporamide derivatives endowed with an antidiabetic effect and attenuated adverse effects as novel selective PPAR $\gamma$ modulators [14].

With the aim of developing new heterocyclic compounds displaying biological activities, our research group also validated cercosporamide as a valuable model in the drug design strategy. Indeed, benzofuran derivatives exhibited promising antiproliferative activity against two human non-small cell lung cancer (NSCLC) cell lines [15]. More recently, benzofuro $[3,2-d]$ pyrimidines proved to be interesting agents in antifungal chemotherapy by restoring the susceptibility of resistant strains to azole treatment [16].

Although research on the biological activity of cercosporamide has increased in the last decade, few efforts have been carried out in the design of kinase inhibitor deriva- 
tives. The interest of the collaborators in this field of research [17-22] and the results of the literature highlighting cercosporamide as a kinase inhibitor and targeting human PKC $\alpha / \beta[4]$, Mnk1/2, Jak3, GSK3 $\beta$, ALK4, and Pim-1 [7,8], from nanomolar to low micromolar ranges, prompted us to develop a new series of heterocyclic compounds inspired from cercosporamide (Figure 1).

The choice of polyoxygenated dibenzofurans was consistent with the literature precedent pointing out that such structures are well-established sources of biologically active scaffolds in drug discovery [23-26]. Otherwise, usnic acid, a secondary metabolite isolated from lichens, with structural similarity with cercosporamide was described as a Pim-1/2 inhibitor and active against myeloid leukemia $[27,28]$. Consequently, the hydroxy groups installed in positions 1 and 3 of the dibenzo[b,d]furan core structure will provide the structural requirements for a possible interaction with the ATP-binding site of the targeted kinase. In positions $7\left(\mathrm{R}_{2}\right)$ and $8\left(\mathrm{R}_{3}\right)$ of the molecule, additional hydroxyl and/or acetyl groups present in cercosporamide and usnic acid could also promote the binding of the designed compounds. Other modulations, including nitro, amino, fluoro, and trifluoromethyl groups, were also considered for the structure-activity relationship (SAR) study.

Taking into account the biological activity of the structural models used in the study, the main goal of the project was to obtain novel Pim-1/Pim-2 kinase inhibitors as anticancer agents. Indeed, the overexpression of serine/threonine Pim kinases (proviral integration site for Moloney murine leukemia virus kinases), in various types of hematological malignancies and solid carcinomas, is characterized in the literature, and these proteins promote cell proliferation and survival [29-31]. Consequently, Pim kinases were considered as a valuable target for antitumor therapy [32-35]. Interestingly, until now, dibenzofurans have not been described in the literature as Pim kinase inhibitors [21,29-31,34,36].

Eight new 1,3-dihydroxydibenzo[ $b, d]$ furan-4-carboxamide derivatives were screened against Pim-1 and Pim-2 and a panel of seven additional mammalian protein kinases to check their selectivity profile. The corresponding methoxy precursors were also evaluated for their kinase inhibition properties to complete the SAR study. Antiproliferative activities of the most promising kinase inhibitors were further tested against seven different cell lines. In complement, the determination of in vivo toxicity using Galleria mellonella larvae was performed. Finally, information of ligand-protein interactions was provided through docking study on Pim-1.

\section{Results and Discussion}

\subsection{Synthesis}

The synthetic strategies to prepare dibenzofurans can be classified into two main categories [37-41] (Figure 2). One involves the construction of the dibenzofuran from the ring closure of diaryl ethers through $\mathrm{C}-\mathrm{C}$ bond formation $[37,38]$. The second approach refers to the intramolecular $O$-arylation of 2-arylphenols according to a mechanism of etherification $[40,41]$.<smiles>[R9]c1cc(O)c(-c2c(O)cc([R9])c(C(N)=O)c2OCC)c([R])c1[R]</smiles>

from 2-arylphenols

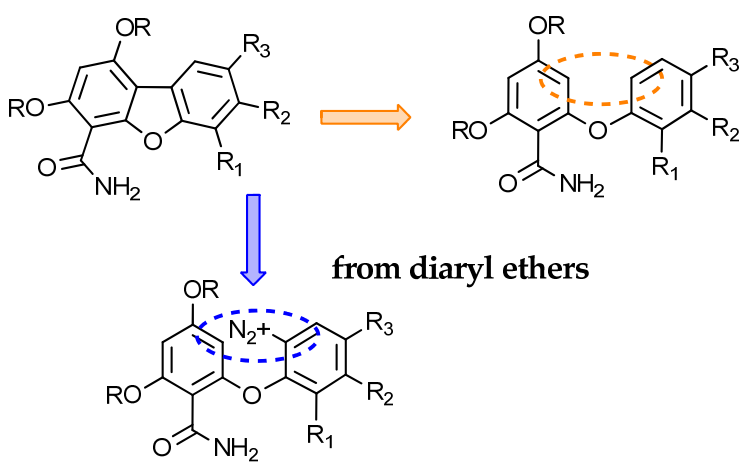

Figure 2. Proposed synthetic strategies to obtain the dibenzo[ $[b, d]$ furan derivatives. 


\subsubsection{Access to Dibenzofuran Derivatives by Intramolecular C-C Bond Formation from Diaryl Ethers}

The first method involves ortho-(aryloxy)aryldiazonium salts as intermediates to form an intramolecular C-C bond via a free-radical cyclization (Figure 2) [42-44]. Before obtaining the diazonium salt, the advantage of this approach relates to the nitro function that promotes the access to diaryl ethers $5-8$ during the initial $\mathrm{SN}_{\mathrm{Ar}}$ reaction between 1-iodo-2-nitrobenzene and phenolic derivatives 1-4 (Scheme 1).<smiles>[R]Oc1cc(O)c([R])c(O[R])c1</smiles>

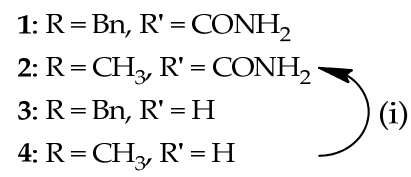<smiles>CCCCCCC</smiles>

low conversion (ii)

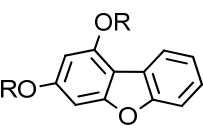

11: $\mathrm{R}=\mathrm{Bn}$

12: $\mathrm{R}=\mathrm{CH}_{3}$

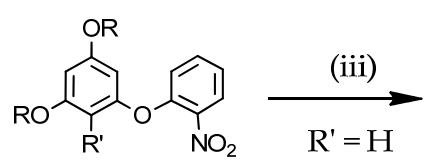

5: $\mathrm{R}=\mathrm{Bn}, \mathrm{R}^{\prime}=\mathrm{CONH}_{2}$ (failure)

6: $\mathrm{R}=\mathrm{CH}_{3}, \mathrm{R}^{\prime}=\mathrm{CONH}_{2}(15 \%)$

7: $\mathrm{R}=\mathrm{Bn}, \mathrm{R}^{\prime}=\mathrm{H}(73 \%)$

8: $\mathrm{R}=\mathrm{CH}_{3}, \mathrm{R}^{\prime}=\mathrm{H}(78 \%)$

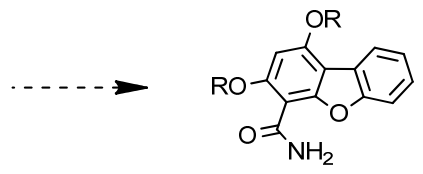

$\mathrm{R}=\mathrm{Bn}, \mathrm{CH}_{3}$
9: $\mathrm{R}=\mathrm{Bn}(65 \%)$

10: $\mathrm{R}=\mathrm{CH}_{3}(92 \%)$

Scheme 1. Reagents and conditions: (i) $\mathrm{CSI}, \mathrm{CH}_{3} \mathrm{CN}, 0{ }^{\circ} \mathrm{C}, 10 \mathrm{~min}$, then $\mathrm{HCl} 5 \mathrm{M}, \mathrm{rt}, 10 \mathrm{~h}, 45 \%$ (ii) $\mathrm{KOH}, \mathrm{DMF}, 120^{\circ} \mathrm{C}, 30 \mathrm{~min}$, then 1-iodo-2-nitrobenzene, $\mathrm{Cu}(0), 170{ }^{\circ} \mathrm{C}, 24 \mathrm{~h}$ (for 5 and 6) and $2 \mathrm{~h}$ (for 7 and 8); (iii) $\mathrm{Zn}$ dust, $\mathrm{NH}_{4} \mathrm{Cl}, \mathrm{CH}_{3} \mathrm{OH}, 80{ }^{\circ} \mathrm{C}, 2 \mathrm{~h}$; (iv) (1) $\mathrm{NaNO}_{2}, \mathrm{H}_{2} \mathrm{SO}_{4}, 0{ }^{\circ} \mathrm{C}, 45 \mathrm{~min},(2) \mathrm{Cu}(0)$, $\mathrm{H}_{2} \mathrm{SO}_{4}, 60{ }^{\circ} \mathrm{C}, 24 \mathrm{~h}, 6 \%$ (for 11 ) and $11 \%$ (for 12) of conversion rates or $\mathrm{Pd}(\mathrm{OAc}){ }_{2}, \mathrm{EtOH}, 60^{\circ} \mathrm{C}, 24 \mathrm{~h}$, $8 \%$ (for 11 ), and $28 \%$ (for 12 ) of conversion rates.

The standard copper-catalyzed Ullmann diaryl ether synthesis [45,46] was first performed in the presence of the previously synthesized phenol derivative $\mathbf{1}$ [16] and its dimethyl analogue $\mathbf{2}$, obtained in the same conditions from commercially available 3,5dimethoxyphenol 4. This route could allow the introduction of the carboxamide function before the heterocyclization step. Unfortunately, no reaction occurred for the dibenzylated phenol 1, and its dimethyl counterpart 2 gave only a poor yield of $15 \%$ after the one-day reaction (Scheme 1). Modification of the combination of the copper source (CuI), base $\left(\mathrm{Cs}_{2} \mathrm{CO}_{3}, \mathrm{NaH}\right)$, and additional ligand ( $N, N$-dimethylglycine) did not improve the completion of the reaction. Interestingly, the same reaction carried out from phenols 3 [16] and 4, without carboxamide substitution, afforded the desired diaryl ethers $\mathbf{7}$ and $\mathbf{8}$ in good yields (73\% and $78 \%$, respectively). This result indicated that the reaction is more sensitive to the electronic-withdrawing effect of the carboxamide and the steric hindrance in the ortho position of the phenol than to the bulky benzyl-protecting groups.

Nitro-diaryl ethers $\mathbf{7}$ and $\mathbf{8}$ were further reduced into the corresponding anilines $\mathbf{9}$ and 10 in a moderate to good yield, respectively (Scheme 1). In the presence of zinc dust and ammonium chloride [47] in methanol, for better solubility, it was necessary to warm the medium to $80^{\circ} \mathrm{C}$ to achieve a complete conversion of the hydroxylamine intermediate to the amino group. Cyclization of the compounds $\mathbf{9}$ and $\mathbf{1 0}$ proceeded after transformation of the amino function into the corresponding diazonium salts, which were then heated with copper powder [48] or palladium acetate [37] to form the dibenzo[b,d]furans $\mathbf{1 1}$ and 12. Unfortunately, the conversion rates, measured by UPLC-MS analysis, to the target compounds remained very low (6 to $28 \%$ ), limiting the application of this route further. The major products of the reaction were the corresponding diaryl ethers with loss of the amino group.

However, this synthetic route enabled us to obtain a very useful intermediate compound $\mathbf{8}$ to ensure the continuation of the project. Indeed, taking into account our literature 
survey, an intramolecular palladium(II)-catalyzed oxidative carbon-carbon bond formation, according to Fagnou's conditions $[49,50]$, would allow us to access a nitrodibenzofuran derivative $\mathbf{1 3}$ whose nitro function is easily replaced by a hydrogen via the reduction of the corresponding diazonium salt (Scheme 2). Additionally, this approach has the advantage of functionalizing the dibenzofuran scaffold with a nitro group, providing functional diversity, after reduction to the corresponding amine for instance.<smiles>COc1cc(OC)cc(Oc2ccccc2[N+](=O)[O-])c1</smiles>

8

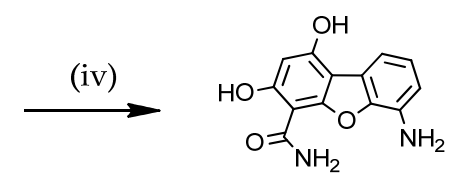

16

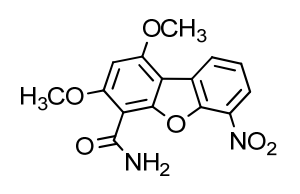

14

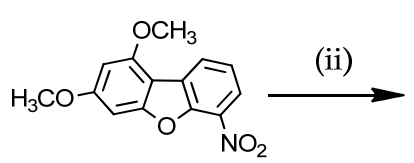

13

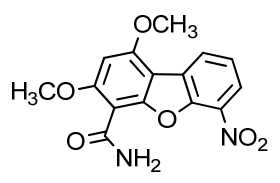

14

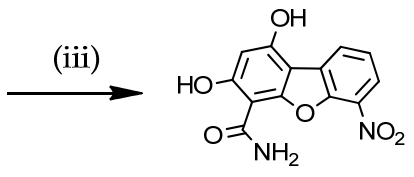

15<smiles>CC(C)COc1cc(O)c2c(oc3ccccc32)c1NC(N)=O</smiles>

17

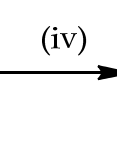

(iv)

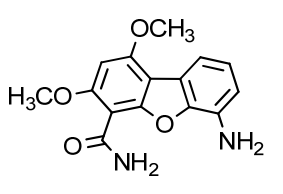

18
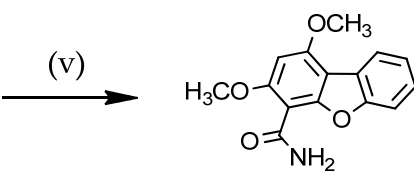

19

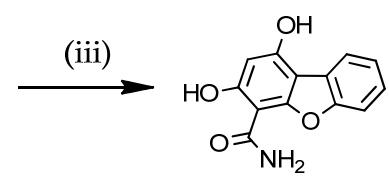

17

Scheme 2. Reagents and conditions: (i) $\mathrm{Pd}(\mathrm{OAc})_{2}, \mathrm{AcOAg}$, $\mathrm{PivOH}, 130{ }^{\circ} \mathrm{C}, 4 \mathrm{~h}, 72 \%$; (ii) $\mathrm{CSI}, \mathrm{CH}_{3} \mathrm{CN}, \mathrm{rt}, 12 \mathrm{~h}$, then $\mathrm{HCl} 5 \mathrm{M}$, rt, 6 h, 53\%; (iii) Pyridine. $\mathrm{HCl}, 200{ }^{\circ} \mathrm{C}, \mathrm{MW}, 15 \mathrm{~min}, 51 \%$ (for 15) and 48\% (for 17); (iv) $\mathrm{Zn}$ dust, $\mathrm{NH}_{4} \mathrm{Cl}_{1} \mathrm{CH}_{3} \mathrm{OH}, 80{ }^{\circ} \mathrm{C}, 2 \mathrm{~h}$, $62 \%$ (for 16) and $49 \%$ (for 18); (v) $\mathrm{NaNO}_{2}, \mathrm{H}_{2} \mathrm{SO}_{4}, \mathrm{EtOH}, 0{ }^{\circ} \mathrm{C}, 30 \mathrm{~min}$, then $80{ }^{\circ} \mathrm{C}, 45 \mathrm{~min}, 52 \%$ (for 17) and $46 \%$ (for 19).

Following Pd-mediated $\mathrm{CH}$ activation conditions, the dibenzofuran ring closure was performed, from nitro-diaryl ether 8, in the presence of silver acetate (AcOAg) in pivalic acid as solvent at $130{ }^{\circ} \mathrm{C}$ with a $72 \%$ yield. Afterwards, a direct aminocarbonylation at the C-4 position of the dibenzofuran derivative $\mathbf{1 4}$, using chlorosulfonyl isocyanate (CSI) as an electrophilic reagent, led to compound $\mathbf{1 4}$ after acidic hydrolysis of the corresponding $\mathrm{N}$-chlorosulfonylcarboxamide intermediate $[15,16,51]$. Demethylation of the methoxy groups was then carried out by heating compound $\mathbf{1 4}$ in neat pyridine hydrochloride at $200{ }^{\circ} \mathrm{C}$, under microwave irradiation (MW), to lead in a short time (15 min) to the dihydroxy derivative 15, available for biological testing [52]. The nitro function was then reduced by using zinc and ammonium chloride, as described above, to afford the final amino compound 16. Finally, deamination of dibenzofuran derivative 16, via the thermal decomposition of the corresponding diazonium salt with the release of nitrogen, furnished the unsubstituted target compound $\mathbf{1 7}$. To scope the synthetic approach further, the nitro derivative $\mathbf{1 4}$ was reduced to afford $\mathbf{1 8}$ as a precursor of the dimethoxy derivative $\mathbf{1 9}$, which could give compound $\mathbf{1 7}$ by an alternative route, after demethylation reaction. By applying such a three-step procedure from compound 14, the global yield decreased by comparison to the initial strategy $(11 \%$ vs. $16.5 \%)$ but the dimethoxy precursors $\mathbf{1 4}, \mathbf{1 8}$, and 19 of the dihydroxy-dibenzofurans 15,16, and 17, respectively, were obtained for complete SAR study.

According to Liégault et al. [49], the ortho-directed $\mathrm{CH}$ activation of diaryl ethers, discussed above for accessing dibenzofurans, tolerates a broad substrate scope including both electron-rich and electron-deficient derivatives. Consequently, this approach was envisaged for pharmacomodulation of $R_{1}, R_{2}$, and $R_{3}$ of the additional target compounds (Figure 1 ). The first step consisted of the synthesis of the suitable aryl iodide derivatives (Scheme 3) for the preparation of starting diaryl ethers (Scheme 4). To this end, the acetylation of 3-iodophenol $\mathbf{2 0}$ was readily achieved with acetic anhydride in pyridine [15] to offer phenyl acetate derivative 21, which was engaged in a Fries 
rearrangement reaction in the presence of boron trifluoride-acetic acid complex $\left(\mathrm{BF}_{3} \cdot 2 \mathrm{CH}_{3} \mathrm{COOH}\right)$ to give 2-hydroxyacetophenone 22 in a good yield of 88\% [53]. The protection of the phenol moiety was then carried out using iodomethane in basic conditions to obtain compound 23 in good yield (Scheme 4). The same protocol was employed to obtain 3-iodoanisole 24 from 3-iodophenol 20.

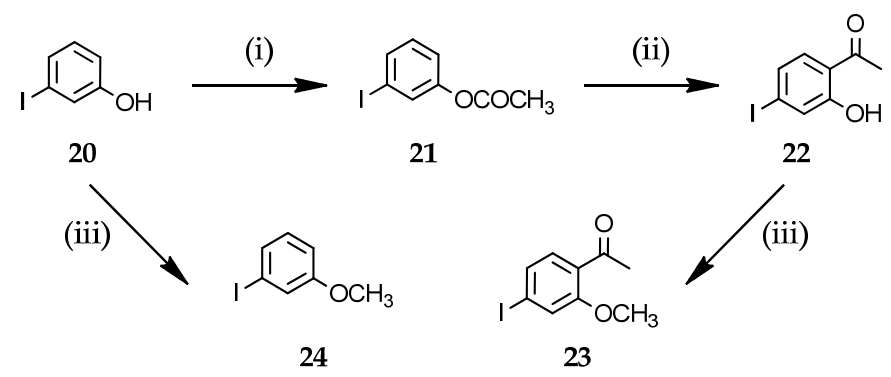

Scheme 3. Reagents and conditions: (i) $\mathrm{Ac}_{2} \mathrm{O}$, Pyridine, $130{ }^{\circ} \mathrm{C}, 2 \mathrm{~h}, 90 \%$; (ii) $\mathrm{BF}_{3} \cdot 2 \mathrm{CH}_{3} \mathrm{COOH}$, $180{ }^{\circ} \mathrm{C}, 12 \mathrm{~h}, 88 \%$; (iii) $\mathrm{CH}_{3} \mathrm{I}, \mathrm{Cs}_{2} \mathrm{CO}_{3}, \mathrm{CH}_{3} \mathrm{CN}, 70{ }^{\circ} \mathrm{C}, 2 \mathrm{~h}, 91 \%$ (for 23 ) and $4 \mathrm{~h}, 89 \%$ (for 24 ).

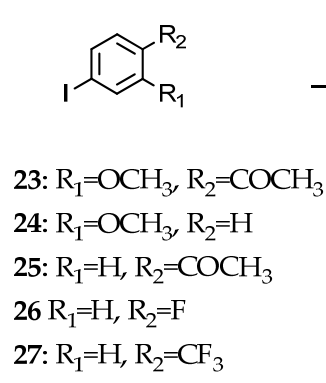<smiles>[R]c1ccc(Oc2cc(OC)cc(OC)c2)cc1[R]</smiles>

28: $\mathrm{R}_{1}=\mathrm{OCH}_{3}, \mathrm{R}_{2}=\mathrm{COCH}_{3}(34 \%)$

29: $\mathrm{R}_{1}=\mathrm{OCH}_{3}, \mathrm{R}_{2}=\mathrm{H}(30 \%)$

30: $\mathrm{R}_{1}=\mathrm{H}, \mathrm{R}_{2}=\mathrm{COCH}_{3}(71 \%)$

31: $\mathrm{R}_{1}=\mathrm{H}, \mathrm{R}_{2}=\mathrm{F}(76 \%)$

32: $\mathrm{R}_{1}=\mathrm{H}, \mathrm{R}_{2}=\mathrm{CF}_{3}(70 \%)$ (ii)<smiles>[R]c1cc2oc3cc(OC)cc(OC)c3c2cc1[R]</smiles>

34: $\mathrm{R}_{1}=\mathrm{OCH}_{3}, \mathrm{R}_{2}=\mathrm{H}(91 \%)$

35: $\mathrm{R}_{1}=\mathrm{H}, \mathrm{R}_{2}=\mathrm{COCH}_{3}(83 \%)$

36: $\mathrm{R}_{1}=\mathrm{H}, \mathrm{R}_{2}=\mathrm{F}(42 \%)$

37: $\mathrm{R}_{1}=\mathrm{H}, \mathrm{R}_{2}=\mathrm{CF}_{3}(39 \%)$

Scheme 4. Reagents and conditions: (i) 3,5-Dimethoxyphenol 4, $\mathrm{Cs}_{2} \mathrm{CO}_{3}, \mathrm{CuI}, \mathrm{DMF}, 110{ }^{\circ} \mathrm{C}, \mathrm{MW}, 1 \mathrm{~h}$; (ii) $\mathrm{Pd}(\mathrm{OAc})_{2}, \mathrm{AgOAc}$, PivOH, $130{ }^{\circ} \mathrm{C}$, 4-24 h; (iii) CSI, $\mathrm{CH}_{3} \mathrm{CN}, 0{ }^{\circ} \mathrm{C}-\mathrm{rt}, 6-12 \mathrm{~h}$, then $\mathrm{HCl}$ 5M, rt, 6-12 h; (iv) Pyridine.HCl, $200{ }^{\circ} \mathrm{C}, \mathrm{MW}, 15 \mathrm{~min}$; (v) $\mathrm{AcCl}, \mathrm{AlCl}_{3}, \mathrm{Cl}-\mathrm{CH}_{2} \mathrm{CH}_{2} \mathrm{Cl}, \mathrm{rt}, 1 \mathrm{~h}, 74 \%$.

Diaryl ethers 28-32 were furnished by Ullmann-type coupling between 3,5-dimethoxyphenol 4 and synthesized $(\mathbf{2 3}, \mathbf{2 4})$ or commercially available (25-27) aryl iodides (Scheme 4) [50]. It should be noted that the presence of a methoxy group on aryl halides has a deleterious effect for the reaction yield when comparing compounds 28, 29 (30-34\%), and 30-32 (70-76\%). Otherwise, the addition of $N, N$-dimethylglycine ligand in the mixture, to stabilize the copper complex, or increased reaction time did not improve the yields. Afterwards, the general reaction sequence (Scheme 4) was the same as previously discussed: (1) Pd-catalyzed CH activation for the dibenzofuran ring closure, from moderate to good yields (compounds 33-37); (2) introduction of the carbamoyl group, in low yields, through electrophilic attack of CSI and acidic hydrolysis (compounds 38-42); and (3) demethylation using pyridinium hydrochloride, in poor yields (compounds 43-47) due to difficulties in the purification on column chromatography. Interestingly, Friedel-Crafts acetylation performed on compound 39, in the presence of acetyl chloride and aluminum trichloride in 1,2-dichloroethane, allowed isolation of compound 38 with a good yield 
of $74 \%$ (Scheme 4) [54]. The proton NMR data validated the regioselective $\mathrm{SE}_{\mathrm{Ar}}$ at the position 8 of the heterocycle.

\subsubsection{Access to Dibenzofuran Derivatives by Intramolecular C-O Bond Formation} from 2-Aryl Phenols

In a final strategy for the access to the dibenzo $[b, d]$ furan scaffold, we were interested in exploring the carbon-oxygen bond formation of 2-aryl phenols in our series [52]. In addition, it gave us the opportunity to confirm the regioselectivity of the carbamoyl introduction at the C4-position of the dibenzofuran ring by performing the reaction from benzamide derivative 2 , where the $\mathrm{CONH}_{2}$ group was already installed (Scheme 5).<smiles>COc1cc(O)c(C(N)=O)c(OC)c1</smiles>

2

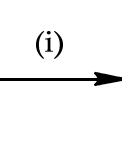<smiles>COc1cc(OC)c(C(N)=O)c(O)c1I</smiles>

48

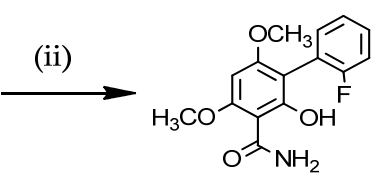

49

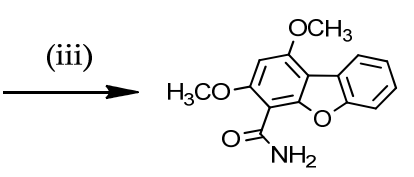

19

Scheme 5. Reagents and conditions: (i) $\mathrm{NIS}, \mathrm{CH}_{2} \mathrm{Cl}_{2}, 0^{\circ} \mathrm{C}, 10 \mathrm{~min}, 60 \%$; (ii) 2-Fluorophenylboronic acid, $\mathrm{Pd}(\mathrm{OAc})_{2}, \mathrm{PPh}_{3}$, $\mathrm{K}_{3} \mathrm{PO}_{4}, \mathrm{CH}_{3} \mathrm{CN} / \mathrm{H}_{2} \mathrm{O}(4 / 1)$ sealed tube, $90{ }^{\circ} \mathrm{C}, \mathrm{MW}, 2 \mathrm{~h}, 26 \%$; (iii) $\mathrm{Cs}_{2} \mathrm{CO}_{3}, \mathrm{CH}_{3} \mathrm{CN}, 150{ }^{\circ} \mathrm{C}, \mathrm{MW}, 1 \mathrm{~h}, 61 \%$.

From this perspective, mono-iodination of compound 2 was first realized in the presence of $N$-iodosuccinimide to afford ortho-iodophenol derivative 48 [16]. In the next step, we followed the strategy described by Jepsen et al. [52] consisting of the introduction of an ortho-fluorophenyl for subsequent intramolecular cyclisation. Thus, the palladiumcatalyzed Suzuki-Miyaura coupling between 2-fluorophenylboronic acid and compound 48, in the presence of palladium acetate, triphenylphosphine, and potassium phosphate as a base, provided the expected compound 49 [55]. Unfortunately, the yield remained very low $(26 \%)$, but a preliminary attempt of C-C bond formation using Jepsen's conditions under microwave irradiation $\left(\mathrm{PdCl}_{2}\left(\mathrm{PPh}_{3}\right)_{2}, \mathrm{~K}_{2} \mathrm{CO}_{3}, \mathrm{DME} / \mathrm{H}_{2} \mathrm{O}, 80{ }^{\circ} \mathrm{C}, \mathrm{MW}, 2 \mathrm{~h}\right)$ [52] proved to be unsuccessful with degradation of the reaction mixture.

Finally, the reaction of biaryl 49 with cesium carbonate at $150{ }^{\circ} \mathrm{C}$ in acetonitrile, under microwave irradiation, furnished compound 19, involving a fluorine atom as the leaving group for nucleophilic substitution. The NMR data and physicochemical properties of the compound obtained after ring closure reaction exactly matched with the previously described dibenzofuran derivative 19 in Scheme 2, confirming the proposed regioselectivity of the introduction of the carbamoyl function by CSI reagent. Nevertheless, after analyzing the global results of this synthetic route, optimization work will be necessary regarding the Suzuki-Miyaura coupling to consider it as a valuable approach of our series. Furthermore, when comparing the yield to obtain compound 19 in this reaction sequence $(4.3 \%$ in 4 steps from compound 4 ) and the synthesis developed above (6.7\% in 5 steps from compound 4 , see Schemes 1 and 2), the second approach is less favored.

\subsection{Kinase Assays}

The synthesized compounds were tested using a luminescence-based assay [56] against a panel of nine kinases: Pim-1, Pim-2, CDK5/p25, CDK9/CyclinT, Haspin, CK1 $\varepsilon$, and GSK3 $\beta$ (from human); DYRK1A (from Rattus norvegicus); and CLK1 (from Mus musculus). The results are summarized in Tables 1 and 2 . All these compounds were considered inactive on Haspin, DYRK1A, GSK3 $\beta, C K 1 \varepsilon, C D K 5 / p 25$, and CDK9/CyclinT since they displayed $\mathrm{IC}_{50}$ values above $10 \mu \mathrm{M}$, except fluoro derivative 41 from series A: Haspin $(0.93 \mu \mathrm{M})$ and DYRK1A $(1.33 \mu \mathrm{M})$ and its dihydroxy counterpart 46 belonging to series B Haspin $(0.80 \mu \mathrm{M})$, DYRK1A $(0.69 \mu \mathrm{M})$, CK1 $(0.68 \mu \mathrm{M})$, and CDK9 $(0.92 \mu \mathrm{M})$, which were highlighted as less selective kinase inhibitors: (Table 1, entries 14 and 15). Globally, compounds bearing 1,3-dihydroxy groups in the benzamide portion (series B) displayed micromolar to submicromolar inhibition of both Pim-1 and CLK1 (with the exception of dihydroxydibenzofuran 47 (Table 1, entry 17) inactive on CLK1 kinase), in contrast 
with the results obtained for the 1,3-dimethoxy analogues (series A, with the exception of compounds 19 and 41 (Table 1, entries 6 and 14) displaying submicromolar $\mathrm{IC}_{50}$ values against CLK1 kinase) and irrespective of the substituents in $R_{1}, R_{2}$, or $R_{3}$.

Table 1. Kinase selectivity profile of dibenzo[b,d]furan derivatives (ADP-Glo method at $10 \mu \mathrm{M} \mathrm{ATP).}$

\begin{tabular}{|c|c|c|c|c|c|c|c|c|c|}
\hline \multirow[b]{3}{*}{ Entry } & \multirow[b]{3}{*}{ Compound } & eries A & $\mathrm{NH}_{2}$ & \multicolumn{3}{|c|}{ Series B } & $\mathrm{H}$ & & \\
\hline & & \multirow[b]{2}{*}{ Series } & \multirow[b]{2}{*}{$\mathbf{R}_{1}$} & \multirow[b]{2}{*}{$\mathbf{R}_{2}$} & \multirow[b]{2}{*}{$\mathbf{R}_{3}$} & \multicolumn{4}{|c|}{ Kinase Enzymatic $\mathrm{IC}_{50}(\mu \mathrm{M})^{1,2}$} \\
\hline & & & & & & $\begin{array}{c}\text { CDK5/ } \\
\text { p25 }\end{array}$ & $\begin{array}{l}\text { CDK9/ } \\
\text { CyclinT }\end{array}$ & Pim-1 & CLK1 \\
\hline 1 & Cerco $^{3}$ & & & & & 5.60 & 0.22 & 0.73 & $>10$ \\
\hline 2 & 14 & $\mathrm{~A}$ & $\mathrm{NO}_{2}$ & $\mathrm{H}$ & $\mathrm{H}$ & $>10$ & $>10$ & 3.21 & $>10$ \\
\hline 3 & 15 & $\mathrm{~B}$ & $\mathrm{NO}_{2}$ & $\mathrm{H}$ & $\mathrm{H}$ & $>10$ & $>10$ & 0.18 & 1.22 \\
\hline 4 & 18 & A & $\mathrm{NH}_{2}$ & $\mathrm{H}$ & $\mathrm{H}$ & $>10$ & $>10$ & $>10$ & $>10$ \\
\hline 5 & 16 & $\mathrm{~B}$ & $\mathrm{NH}_{2}$ & $\mathrm{H}$ & $\mathrm{H}$ & $>10$ & $>10$ & 0.13 & 0.45 \\
\hline 6 & 19 & A & $\mathrm{H}$ & $\mathrm{H}$ & $\mathrm{H}$ & $>10$ & $>10$ & $>10$ & 0.75 \\
\hline 7 & 17 & B & $\mathrm{H}$ & $\mathrm{H}$ & $\mathrm{H}$ & $>10$ & $>10$ & 0.23 & 0.26 \\
\hline 8 & 38 & A & $\mathrm{H}$ & $\mathrm{OCH}_{3}$ & $\mathrm{COCH}_{3}$ & $>10$ & $>10$ & $>10$ & $>10$ \\
\hline 9 & 43 & B & $\mathrm{H}$ & $\mathrm{OH}$ & $\mathrm{COCH}_{3}$ & $>10$ & $>10$ & 0.82 & 0.29 \\
\hline 10 & 39 & $\mathrm{~A}$ & $\mathrm{H}$ & $\mathrm{OCH}_{3}$ & $\mathrm{H}$ & $>10$ & $>10$ & $>10$ & $>10$ \\
\hline 11 & 44 & B & $\mathrm{H}$ & $\mathrm{OH}$ & $\mathrm{H}$ & $>10$ & $>10$ & 0.06 & 0.026 \\
\hline 12 & 40 & $\mathrm{~A}$ & $\mathrm{H}$ & $\mathrm{H}$ & $\mathrm{COCH}_{3}$ & $>10$ & $>10$ & $>10$ & $>10$ \\
\hline 13 & 45 & B & $\mathrm{H}$ & $\mathrm{H}$ & $\mathrm{COCH}_{3}$ & $>10$ & $>10$ & 0.28 & 0.14 \\
\hline 14 & 41 & A & $\mathrm{H}$ & $\mathrm{H}$ & F & $>10$ & $>10$ & $>10$ & 0.85 \\
\hline 15 & 46 & B & $\mathrm{H}$ & $\mathrm{H}$ & $\mathrm{F}$ & $>10$ & 0.92 & 1.20 & 0.62 \\
\hline 16 & 42 & A & $\mathrm{H}$ & $\mathrm{H}$ & $\mathrm{CF}_{3}$ & $>10$ & $>10$ & $>10$ & $>10$ \\
\hline 17 & 47 & B & $\mathrm{H}$ & $\mathrm{H}$ & $\mathrm{CF}_{3}$ & $>10$ & $>10$ & 2.35 & $>10$ \\
\hline
\end{tabular}

${ }^{1} \mathrm{IC}_{50}$ values were calculated from dose-response curves. Each inhibitor concentration was tested in duplicate. All protein kinases used here are human with the exception of DYRK1A (Rattus norvegicus) and CLK1 (Mus musculus). DYRK1A: dual specificity tyrosine phosphorylation regulated kinase 1A, CDK: cyclin-dependent kinase, Haspin: haploid germ cell-specific nuclear protein kinase, CLK1: cdc2-like kinase 1, CK1: casein kinase 1, GSK3 3 : glycogen synthase kinase 3, Pim: Proviral integration site for Moloney murine leukemia virus. ${ }^{2}$ All the compounds remained inactive against Haspin, DYRK1A, GSK3 and CK1. Except compound 41: Haspin $(0.93 \mu \mathrm{M})$ and DYRK1A $(1.33 \mu \mathrm{M})$ and compound 46: Haspin $(0.80 \mu \mathrm{M})$, DYRK1A $(0.69 \mu \mathrm{M})$, and CK1 $(0.68 \mu \mathrm{M}) .{ }^{3}$ Cercosporamide (Cerco) was used as the reference compound.

Small variations can be observed depending upon steric constraint or electronic effects. Indeed, the non-substituted compound $\mathbf{1 7}$ (Table 1 , entry 7) showed significant $\mathrm{IC}_{50}$ values of 0.23 and $0.26 \mu \mathrm{M}$ against Pim-1 and CLK1, 3.5-fold more active and comparable to those observed for the disubstituted compound 43 (Table 1, entry 9, IC $\mathrm{I}_{50}$ values of 0.82 and $0.29 \mu \mathrm{M}$, respectively), which appeared the most structurally related to cercosporamide. Compound 44, bearing a 7-OH substituent on the dibenzofuran ring (Table 1, entry 11), displayed the most potent inhibitory activities against both enzymes with $\mathrm{IC}_{50}$ values of 0.06 (Pim-1) and $0.026 \mu \mathrm{M}$ (CLK1) while 7-substitutions by a fluorine atom (compound 46, Table 1, entry 15) or a trifluoromethyl group (compound 47 , Table 1, entry 17) reduced the inhibitory potency against Pim- $1\left(\mathrm{IC}_{50}>1 \mu \mathrm{M}\right)$ and abrogated CLK1 inhibition for 47. Furthermore, the 8-acetyldibenzofuran derivative 45 (Table 1, entry 13) exhibited an increased $\mathrm{IC}_{50}$ value of $0.28 \mu \mathrm{M}$ against Pim-1 and also remained 5-fold less active than 44 against CLK1 with an $\mathrm{IC}_{50}$ value of $0.14 \mu \mathrm{M}$. However, by comparison with compound 43 possessing the $7-\mathrm{OH}$ and $8-\mathrm{COCH}_{3}$ substitution patterns of cercosporamide, compound 45 without hydroxyl has been identified as a better kinase inhibitor towards both discussed enzymes. All these promising compounds belonging to series $\mathrm{B}$ were also potent submicromolar Pim-2 inhibitors (Table 2), with $\mathrm{IC}_{50}$ values ranging from 0.035 (compound 44) to $0.37 \mu \mathrm{M}$ (compound 47). 
Table 2. Enzymatic assays on human Pim-1 and Pim-2 kinases (ADP-Glo method at $10 \mu \mathrm{M}$ ATP).

\begin{tabular}{|c|c|c|c|c|c|c|}
\hline \multirow[b]{2}{*}{ Entry } & \multirow[b]{2}{*}{ Compound } & \multirow[b]{2}{*}{$\mathbf{R}_{\mathbf{1}}$} & \multirow[b]{2}{*}{$\mathbf{R}_{2}$} & \multirow[b]{2}{*}{$\mathbf{R}_{3}$} & \multicolumn{2}{|c|}{$\mathrm{IC}_{50}(\mu \mathrm{M})^{1}$} \\
\hline & & & & & Pim-1 & Pim-2 \\
\hline 1 & Cerco $^{2}$ & & & & 0.73 & 1.43 \\
\hline 2 & 15 & $\mathrm{NO}_{2}$ & $\mathrm{H}$ & $\mathrm{H}$ & 0.18 & 0.33 \\
\hline 3 & 16 & $\mathrm{NH}_{2}$ & $\mathrm{H}$ & $\mathrm{H}$ & 0.13 & 0.085 \\
\hline 4 & 17 & $\mathrm{H}$ & $\mathrm{H}$ & $\mathrm{H}$ & 0.23 & 0.20 \\
\hline 5 & 43 & $\mathrm{H}$ & $\mathrm{OH}$ & $\mathrm{COCH}_{3}$ & 0.82 & 0.14 \\
\hline 6 & 44 & $\mathrm{H}$ & $\mathrm{OH}$ & $\mathrm{H}$ & 0.06 & 0.035 \\
\hline 7 & 45 & $\mathrm{H}$ & $\mathrm{H}$ & $\mathrm{COCH}_{3}$ & 0.28 & 0.12 \\
\hline 8 & 46 & $\mathrm{H}$ & $\mathrm{H}$ & $\mathrm{F}$ & 1.2 & 0.25 \\
\hline 9 & 47 & $\mathrm{H}$ & $\mathrm{H}$ & $\mathrm{CF}_{3}$ & 2.35 & 0.37 \\
\hline
\end{tabular}

${ }^{1} \mathrm{IC}_{50}$ on Pim-1/2 kinase activity was calculated from dose-response curves. Each inhibitor concentration was tested in duplicate. Values are a mean of $n \geq 3$ independent experiments. ${ }^{2}$ Cercosporamide (Cerco) was used reference compound.

Taking into account the kinase inhibitory activity of cercosporamide (Tables 1 and 2, entry 1), the development of dibenzofuran derivatives led us to obtain more potent compounds against Pim- $1 / 2$ or as active compounds as the reference molecule. In addition, the novel compounds gave rise to low micromolar and nanomolar CLK1 inhibition compared to cercosporamide, constituting a very interesting result due to the CLK1 implications in human disease including cancer [57].

\subsection{Docking Studies}

Compounds 44, 43, and cercosporamide exhibit a similar binding mode when docked into the ATP pocket of Pim-1 (Figure 3). The 1-OH position in the benzamide portion forms a H-bond interaction with the carbonyl group of hinge residue Glu121 while the 7-OH position could favor an additional H-bond interaction with the ammonium side chain of conserved residue Lys67 and/or the carboxylate side chain of Asp186 (only visible for the most active compound 44). Such a binding mode is consistent with the experimental data, where 1,3-dihydroxybenzamide series (series B) are more much active than their 1,3-dimethoxy analogues (series A). All the 3-OH are oriented towards the carbonyl group of hinge residue Pro123, but the distance appears to be too large ( $>4.0 \AA)$ to enable the formation of an appropriate H-bond interaction. The 4-carboxamide group does not seem to interact with a particular residue in the ATP-pocket but instead performs an intramolecular $\mathrm{H}$-bond with the furan ring. This contrasts with previous docking studies of cercosporamide in the ATP pocket of Mnk2 kinase that showed H-bond interaction between the 4-carboxamide of the phenyl portion and hinge residues Glu160 and Met162 [8]. However, other docking studies of usnic acid, another dibenzofuran analogue with the main structural difference being 4-acetyl and 2-methyl groups, proposed a different binding mode with Pim-1 kinase, which seems consistent with our hypothesis [27]. Of course, we cannot discard other possible binding modes for these dibenzo $[b, d]$ furan inhibitors since they contain many H-bond donor and acceptor substituents that can interact depending upon the specific environment of each kinase. The information of the role of the amide function in the binding mode of the compounds is under study through the synthesis of the counterparts without amide function. In a rational approach, their binding pose will be compared to their inhibitory potency on Pim-1 to complete the study. 


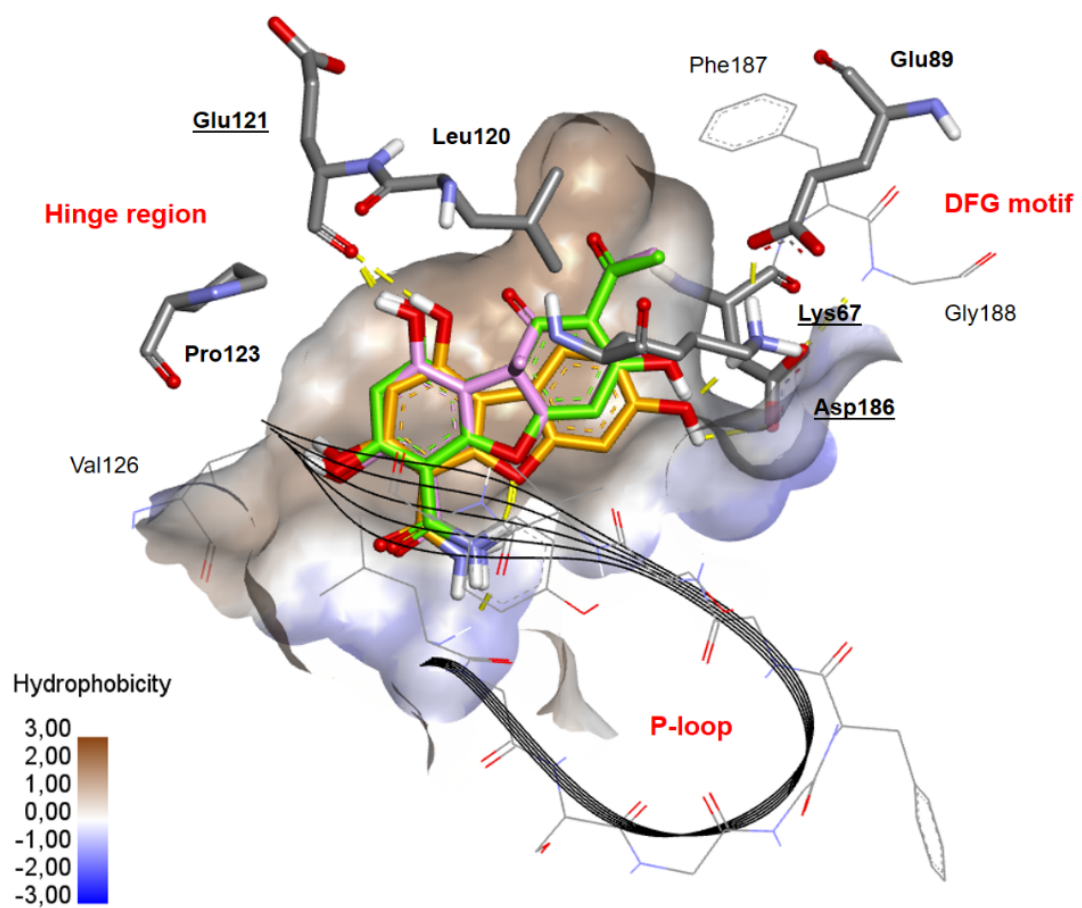

Figure 3. Binding pose found by the docking program GOLD for compound 44 (orange), compound 43 (green), and cercosporamide (pink) within the ATP pocket of Pim-1 (PDB ID 3A99). Hydrogen bonds are indicated as yellow lines.

\subsection{In Vitro Cell-Based Assays and Acute Toxicity Testing}

The Pim-1/2 and CLK-1 inhibitors 15-17 and 43-46, belonging to series $B$, were tested for their antiproliferative activity against six cancer cell lines, and L929 (mouse fibroblasts) for in vitro toxicity evaluation (Table 3, entries 1 to 7). Cercosporamide as a reference and compound 47, being less active against Pim-1 and inactive on CLK1, were also considered in the anticancer screening (Table 3, entries 8 and 9). The commercially available compound SGI-1776, a small-molecule pan-Pim protein kinase inhibitor with $\mathrm{IC}_{50}$ values of 0.05 (Pim-1) and $0.10 \mu \mathrm{M}$ (Pim-2), was used as a positive control for the in vitro studies. Various types of hematological malignancies were selected for in vitro testing: the human acute myeloid leukemia (AML) cell line MV4-11, and the human chronic myeloid leukemia (CML) cell lines KU812 and K562. Indeed, Pim kinases are overexpressed in a wide range of hematopoietic malignancies [27-36]. Solid tumors were also included in the panel of tested cell lines: MCF-7 (human breast adenocarcinoma), HT-29 (human colon adenocarcinoma), and HeLa (human cervical cancer) cells. Cytotoxic effects were evaluated using an MTT assay, and living cells were also counted with the trypan blue dye exclusion method for MV4-11, KU812, and K562 cells. 
Table 3. Cell-based assays of representative dibenzo[ $b, d]$ furane derivatives.

\begin{tabular}{|c|c|c|c|c|c|c|c|c|c|c|}
\hline & & & & & \multicolumn{6}{|c|}{$\mathrm{IC}_{50}(\mu \mathrm{M})^{1,2}$} \\
\hline Entry & Compound & $\mathbf{R}_{1}$ & $\mathbf{R}_{2}$ & $\mathbf{R}_{3}$ & MV4-11 & KU812 & K562 & MCF-7 & HeLa & L929 \\
\hline 1 & 15 & $\mathrm{NO}_{2}$ & $\mathrm{H}$ & $\mathrm{H}$ & $30.7 \pm 1.1$ & $78.4 \pm 2.1$ & $>100$ & $>100$ & $24.7 \pm 6.7$ & $49.2 \pm 1.0$ \\
\hline 2 & 16 & $\mathrm{NH}_{2}$ & $\mathrm{H}$ & $\mathrm{H}$ & $10.1 \pm 0.8$ & $>100$ & $>100$ & $>100$ & $14.6 \pm 7.2$ & $>100$ \\
\hline 3 & 17 & $\mathrm{H}^{2}$ & $\mathrm{H}$ & $\mathrm{H}$ & $14.3 \pm 1.1$ & $>100$ & $>100$ & $>100$ & $9.5 \pm 4.1$ & $>100$ \\
\hline 4 & 43 & $\mathrm{H}$ & $\mathrm{OH}$ & $\mathrm{COCH}_{3}$ & $52.2 \pm 1.7$ & $>100$ & $>100$ & $>100$ & $57.1 \pm 7.6$ & $>100$ \\
\hline 5 & 44 & $\mathrm{H}$ & $\mathrm{OH}$ & $\mathrm{H}$ & $2.6 \pm 0.4$ & $42.1 \pm 1.3$ & $\begin{array}{c}75.7 \pm \\
11.8\end{array}$ & $52.5 \pm 1.2$ & $10.2 \pm 1.2$ & $28.4 \pm 1.1$ \\
\hline 6 & 45 & $\mathrm{H}$ & $\mathrm{H}$ & $\mathrm{COCH}_{3}$ & $8.8 \pm 0.9$ & $\begin{array}{c}69.4 \pm \\
12.9\end{array}$ & $>100$ & $>100$ & $59.6 \pm 7.6$ & $>100$ \\
\hline 7 & 46 & $\mathrm{H}$ & $\mathrm{H}$ & $\mathrm{F}$ & $16.1 \pm 1.6$ & $>100$ & $>100$ & - & - & - \\
\hline 8 & 47 & $\mathrm{H}$ & $\mathrm{H}$ & $\mathrm{CF}_{3}$ & $>100$ & $>100$ & $>100$ & - & - & - \\
\hline 9 & Cerco $^{3}$ & & & & $31.5 \pm 4.7$ & $>100$ & $>100$ & $44.3 \pm 2.1$ & $7.5 \pm 3.1$ & - \\
\hline 10 & Doxo $^{3}$ & & & & - & - & - & $\begin{array}{c}0.50 \pm \\
0.02\end{array}$ & $2.7 \pm 0.2$ & $2.4 \pm 0.4$ \\
\hline 11 & $\begin{array}{c}\text { SGI-1776 } \\
3\end{array}$ & & & & $\begin{array}{c}0.030 \pm \\
0.003\end{array}$ & $3.5 \pm 0.6$ & $3.7 \pm 1.5$ & - & - & - \\
\hline
\end{tabular}

${ }^{1} \mathrm{IC}_{50}$ HT-29 $>100 \mu \mathrm{M}$ for all the compounds and Cerco $\mathrm{IC}_{50}=10.4 \pm 2.5 \mu \mathrm{M}$; Doxo $\mathrm{IC}_{50}=0.72 \pm 0.5 \mu \mathrm{M} .{ }^{2}$ Values are a mean of $\mathrm{n} \geq 3$ independent experiments. Cells were treated with concentrations ranging from $100 \mathrm{nM}$ to $100 \mu \mathrm{M}$ for $48 \mathrm{~h}$ or $72 \mathrm{~h}$ (MCF-7, Hela and L929). Cell viability was then determined by MTT assays, and $\mathrm{EC}_{50}$ values were calculated using Graphpad PRISM 7 software ( $n=3$ in triplicate; data are in the mean \pm SEM). -: Not determined. ${ }^{3}$ Cercosporamide (Cerco) was used as the reference compound. Doxorubicin (Doxo) and SGI-1776 were used as positive controls.

In a general trend, all the dibenzofuran derivatives, except 47 (Table 3, entry 8), displayed moderate to good antiproliferative activity against the AML cell line MV4-11, with $\mathrm{IC}_{50}$ values ranging from $2.6 \pm 0.4$ to $52.2 \pm 1.7 \mu \mathrm{M}$ (Table 3, entries 1-7). Compound 44 was the most active compound but remained nearly 90 -fold less active than the reference drug SGI-1776 on this cell (Table 3, entry 11). Interestingly, compounds 44, 45, 16, and 17, exhibiting the best in vitro cytotoxic effects $\left(\mathrm{IC}_{50}\right.$ values from $2.6 \pm 0.4$ to $\left.14.3 \pm 1.1 \mu \mathrm{M}\right)$, also possessed the best enzymatic activity inhibition against $\mathrm{HsPim} 1 / 2\left(\mathrm{IC}_{50}\right.$ values from 0.06 to $0.28 \mu \mathrm{M}$ on Pim- 1 and $\mathrm{IC}_{50}$ values from 0.035 to $0.20 \mu \mathrm{M}$ on Pim-2) with additional impact on CLK1 kinase ( $\mathrm{IC}_{50}$ values from 0.026 to $0.45 \mu \mathrm{M}$ ). Notably, compound 46 , slightly less active on MV4-11 cells (Table 3, entry 7), and compounds 15 and 43, with decreased cell growth inhibition on the same cell line (Table 3, entries 1 and 4), showed increased $\mathrm{IC}_{50}$ values against $\mathrm{HsPim}-1$ ( $\mathrm{IC}_{50}$ of $1.20 \mu \mathrm{M}$, for compound 46 and $0.82 \mu \mathrm{M}$, for compound 43) or CLK1 $\left(\mathrm{IC}_{50}=1.22 \mu \mathrm{M}\right.$, for compound 15) (Table 1, entries 15, 9, and 3). Moreover, the inactive compound 47 against the MV4-11 cell lines displayed a higher $\mathrm{IC}_{50}$ value of $2.35 \mu \mathrm{M}$ against Pim-1 and was also inactive towards CLK1 kinase. It must be noticed that the majority of dihydroxydibenzofuran derivatives designed in the frame of that project showed better activity than cercosporamide $\left(\mathrm{IC}_{50}=31.5 \pm 4.7 \mu \mathrm{M}\right)$ against MV4-11 cells.

Regarding the antileukemia effect of the compounds, it is noteworthy that disappointing pharmacological results against CML cell lines, namely KU812 and K562, suggested a selective effect on AML cell growth (Table 3). Considering the other types of tumors, all the tested compounds remained totally inactive against the MCF-7 cell line, except $44\left(\mathrm{IC}_{50}=52.5 \pm 1.2 \mu \mathrm{M}\right)$ with moderate potency. In the contrary, HeLa cells proved to be very sensitive to part of the synthesized compounds, with $\mathrm{IC}_{50}$ values ranging from $9.5 \pm 4.1$ to $24.7 \pm 6.7 \mu \mathrm{M}$, for the most active compounds and at the level of cercosporamide (Table 3, entry 9) for analogues 44 and $\mathbf{1 7}$ (Table 3, entries 5 and 3).

Against L929 normal cells, no cytotoxicity (Table 3, entries 2-4 and 6) or poor cytotoxicity (Table 3, entries 1 and 5) was observed, strengthening the interest in the series in terms of the selectivity index. Complementing this study, the determination of in vivo 
toxicity, using Galleria mellonella larvae [22], was performed for all the compounds involved in the antitumor assays. Indeed, Galleria mellonella has been demonstrated to be a more robust assessment of the likely toxicity of chemicals in mammals than cell lines [58]. Groups of 10 larvae were injected with $10 \mu \mathrm{L}$ of compound at a dose varying from 10 to $50 \mathrm{mg} / \mathrm{kg}$. The mortality was recorded daily for 7 days. Percentage survival was plotted for each compound using Graph Pad Prism. No reduction of viability and no sign of cuticular darkening were observed for any compounds, except for $\mathbf{1 6}$ and $\mathbf{4 5}$, at a dose of $50 \mathrm{mg} / \mathrm{kg}$ after 7 days (Figure 4). Survival analysis was done using the log-rank test and the Kaplan-Meier survival curves for these two compounds. Concerning 16, the 2 tests showed non-significant p-values ( 0.1464 and 0.1468 , respectively) and allowed the conclusion that the survival curve was not significantly different to the other compounds. Concerning 45, the same conclusions were obtained with p-values equal to 0.3173 for the two tests. These encouraging results prompted us to conclude to a general nontoxic effect in vivo in this model and at the considered dose.

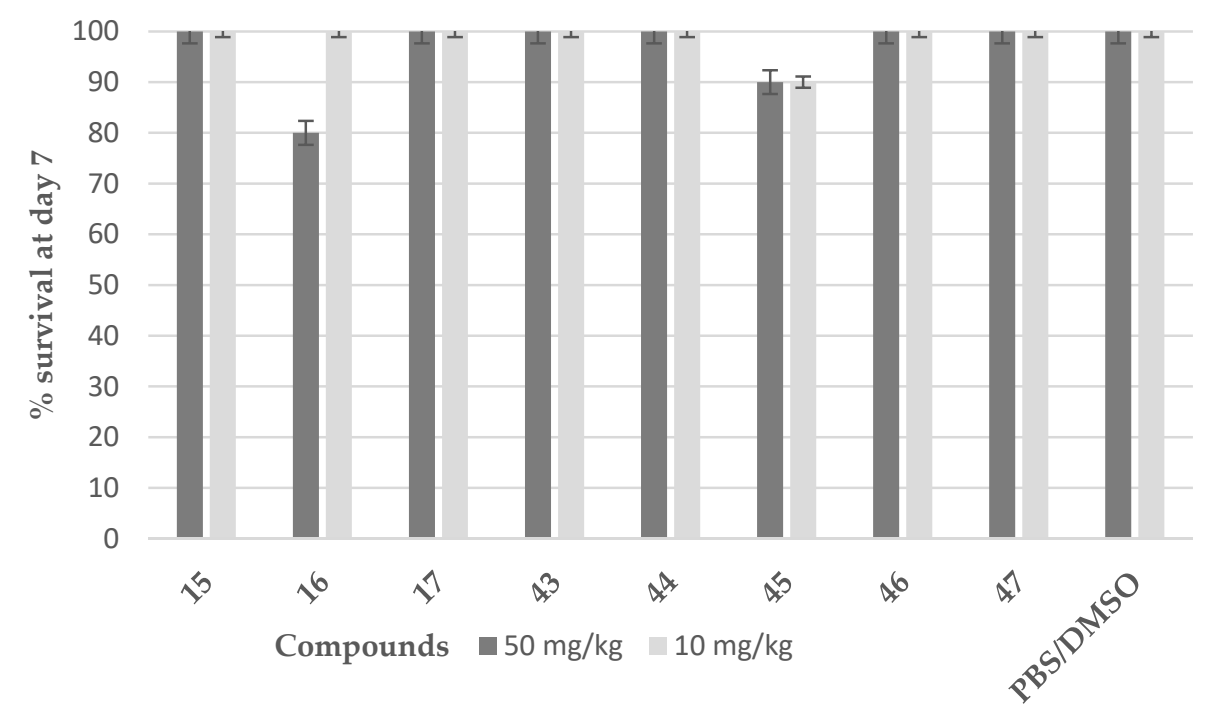

Figure 4. Evaluation of the in vivo cytotoxicity of dibenzofuran derivatives $15-17$ and $43-47$ on the G. mellonella model. Percentage of survival 7 days after injection of doses of 10 and $50 \mathrm{mg} / \mathrm{kg}$ for each compound. Mean of two independent experiments.

\section{Materials and Methods}

\subsection{Chemistry}

\subsubsection{General Experimental Procedures}

All commercial reagents were used without further purification. All solvents were reagent or HPLC grade. Analytical TLC was performed on silica gel 60 F254 plates. Open column chromatography was performed on silica gel 60 (70-230 mesh ASTM, MachereyNagel GmbH \& Co. KG, Düren, Germany). The flash column chromatography was performed using a Reveleris ${ }^{\circledR}$ X2 Buchi system, with a Buchi cartridge. Yields refer to chromatographically and spectroscopically pure compounds. Melting points were determined on an electrothermal melting point (Thermo Fisher Scientific, Illkirch, France) apparatus. ${ }^{1} \mathrm{H} \mathrm{NMR}$ and ${ }^{13} \mathrm{C}$ NMR spectra were recorded in $\mathrm{CDCl}_{3}$ or in DMSO- $d_{6}$ on a $400 \mathrm{MHz}$ spectrometer. Chemical shifts are reported as $\delta$ values in parts per million (ppm) relative to tetramethylsilane as the internal standard and coupling constants $(\mathrm{J})$ are given in hertz. Multiplicities are reported as follows: $\mathrm{s}=$ singlet, $\mathrm{d}=$ doublet, $\mathrm{dd}=$ doublet of doublets, $\mathrm{t}=$ triplet, $\mathrm{mt}=$ multiplet, $\mathrm{bs}=$ broad singlet, $\mathrm{tapp}=$ apparent triplet. All the spectra are provided in the "Supplementary Materials". Low-resolution mass spectra were recorded using an electrospray ionization (ESI) method with a Waters ZQ 2000 spectrometer (Waters, Saint Quentin en Yvelines, France). The UPLC column used was an Acquity UPLC ${ }^{\circledR}$ BEH Phenyl (2.1 mm i.d., $50 \mathrm{~mm}$ length, $1.7 \mu \mathrm{m}$ particle size, Waters, Saint Quentin en Yvelines, 
France) from Waters. A linear mobile phase gradient was used with mobile phase A as $100 \%$ of acetonitrile in water (at $2 \%$ ) and mobile phase $\mathrm{B}$ as $100 \%$ acetonitrile. The gradient table was: $0-0.5 \mathrm{~min}, 0 \% \mathrm{~B} ; 0.5-4.0 \mathrm{~min} 0 \rightarrow 100 \% \mathrm{~B} ; 4.0-5.5 \% 100 \% \mathrm{~B} ; 5.5-5.7 \mathrm{~min} 100 \rightarrow 0 \%$ $\mathrm{B} ; 5.7-7.5 \mathrm{~min} 0 \% \mathrm{~B}$ at a flow rate of $0.5 \mathrm{~mL} \cdot \mathrm{min}^{-1}$ and column temperature of $35^{\circ} \mathrm{C}$. Formic acid $(0.1 \%)$ was added in diluent to improve ionization. For compounds $\mathbf{1 4 - 1 9}$ and 38-47, high-resolution mass spectrometry (HRMS) was recorded on a Waters Vion IMS QTof instrument (SAA055K, Waters, Manchester, UK) coupled with an Acquity H-Class UPLC in ESI+ mode. IR absorption spectra were recorded on an ATR-FTIR equipment, MIRacle Shimadzu spectrometer (Shimadzu Corporation, Kyoto, Japan). Only the most significant bands were reported. Microwave reactions were carried out in a CEM Discover microwave reactor (CEM SAS, Saclay, France) in sealed vessels (monowave, maximum power $300 \mathrm{~W}$, temperature control via IR-sensor, fixed temperature).

Compounds 1, 3, and cercosporamide were synthesized or obtained following procedures previously described [16].

3.1.2. Access to Dibenzofuran Derivatives $\mathbf{1 4 - 1 9}$ by Intramolecular C-C Bond Formation from Diaryl Ethers

2-Hydroxy-4,6-dimethoxybenzamide (2)

To a stirred suspension of 3,5-dimethoxyphenol $4(1.00 \mathrm{~g}, 6.5 \mathrm{mmol})$ in acetonitrile $(20 \mathrm{~mL})$ at $0{ }^{\circ} \mathrm{C}$ under argon, chlorosulfonyl isocyanate $(1.26 \mathrm{~mL}, 13 \mathrm{mmol})$ was added. The mixture was maintained at this temperature for $10 \mathrm{~min}$ and then the reaction mixture was quenched with $\mathrm{HCl} 5 \mathrm{M}(20 \mathrm{~mL})$. After $10 \mathrm{~h}$ at room temperature, the reaction was diluted with water $(100 \mathrm{~mL})$ and extracted with dichloromethane $(3 \times 50 \mathrm{~mL})$. The combined organic extracts were dried over sodium sulfate and filtered. The solvent was evaporated in vacuo and the residue was purified by silica gel column chromatography using cyclohexane/ethyl acetate (8/2) as eluent to give compound $2(576 \mathrm{mg}, 45 \%$ yield) as a white powder. $R_{\mathrm{f}} 0.46$ (cyHex/AcOEt 6:4); Mp: $154-155{ }^{\circ} \mathrm{C} ;{ }^{1} \mathrm{H}$ NMR $\left(400 \mathrm{MHz}, \mathrm{DMSO}-d_{6}\right) \delta$ $14.69(\mathrm{~s}, 1 \mathrm{H}, \mathrm{OH}), 8.04-7.86\left(\mathrm{~m}, 2 \mathrm{H}, \mathrm{CONH}_{2}\right), 6.08\left(\mathrm{~d}, J=2.5 \mathrm{~Hz}, 1 \mathrm{H}, \mathrm{H}_{5}\right), 6.05(\mathrm{~d}, J=2.4 \mathrm{~Hz}$, $\left.1 \mathrm{H}, \mathrm{H}_{3}\right), 3.87\left(\mathrm{~s}, 3 \mathrm{H}, \mathrm{CH}_{3}\right), 3.77\left(\mathrm{~s}, 3 \mathrm{H}, \mathrm{CH}_{3}\right) ;{ }^{13} \mathrm{C} \mathrm{NMR}\left(100 \mathrm{MHz}, \mathrm{DMSO}-d_{6}\right) \delta 171.7(\mathrm{C}=\mathrm{O})$, 165.9 $\left(\mathrm{C}_{2}\right), 163.7\left(\mathrm{C}_{6}\right), 160.2\left(\mathrm{C}_{4}\right), 96.6\left(\mathrm{C}_{1}\right), 94.1\left(\mathrm{C}_{3}\right), 90.1\left(\mathrm{C}_{5}\right), 56.0\left(\mathrm{CH}_{3}\right), 55.3\left(\mathrm{CH}_{3}\right) ; \mathrm{IR}$ $\left(\mathrm{cm}^{-1}\right): 3429,3209,1620,1587,1492,1415,1355,1315,1294,1217,1199,1159,1109,1041 ;$ MS (ESI) $m / z(\%): 198.1(100)[\mathrm{M}+\mathrm{H}]^{+} ;$UPLC purity $=97 \%, t_{\mathrm{R}} 1.93 \mathrm{~min}$.

\section{2,4-Dimethoxy-6-(2'-nitrophenoxy)benzamide (6)}

A mixture of 2-hydroxy-4,6-dimethoxybenzamide $2(0.50 \mathrm{~g}, 2.5 \mathrm{mmol})$ and potassium hydroxide $(0.13 \mathrm{~g}, 2.5 \mathrm{mmol})$ was heated to $120^{\circ} \mathrm{C}$ and stirred for $30 \mathrm{~min}$, and then 1-iodo2-nitrobenzene $(0.64 \mathrm{~g}, 2.5 \mathrm{mmol})$ and copper powder $(0.20 \mathrm{~g}, 3.13 \mathrm{mmol})$ were added, respectively. The resulting mixture was stirred at $170{ }^{\circ} \mathrm{C}$ for $24 \mathrm{~h}$ and then cooled down to room temperature. After the addition of water, the aqueous layer was extracted with ethyl acetate $(100 \mathrm{~mL})$ and washed with water $(2 \times 100 \mathrm{~mL})$. The organic layers were washed with brine, dried over sodium sulfate, filtered, and evaporated to dryness. The resulting oil was purified by silica gel column chromatography using cyclohexane/ethyl acetate $(8 / 2)$ as an eluent to give compound 6 (125 mg, $15 \%$ yield) as a brown powder. $R_{\mathrm{f}} 0.45$ (cyHex/AcOEt 8:2); Mp: 209-210 ${ }^{\circ} \mathrm{C}^{1}{ }^{1} \mathrm{H}$ NMR (400 MHz, DMSO-d $\left.d_{6}\right) \delta 13.51$ (s, $\left.1 \mathrm{H}, \mathrm{NH}\right)$, $11.76(\mathrm{~s}, 1 \mathrm{H}, \mathrm{NH}), 8.60\left(\mathrm{dd}, J=8.4,1.5 \mathrm{~Hz}, 1 \mathrm{H}, \mathrm{H}_{3^{\prime}}\right), 8.24\left(\mathrm{dd}, J=8.4,1.5 \mathrm{~Hz}, 1 \mathrm{H}, \mathrm{H}_{6^{\prime}}\right), 7.85$ $\left(\mathrm{t}, J=7.9 \mathrm{~Hz}, 1 \mathrm{H}, \mathrm{H}_{4^{\prime}}\right), 7.46\left(\mathrm{t}, J=7.9 \mathrm{~Hz}, 1 \mathrm{H}, \mathrm{H}_{5^{\prime}}\right), 6.31\left(\mathrm{~d}, J=2.3 \mathrm{~Hz}, 1 \mathrm{H}, \mathrm{H}_{5}\right), 6.24(\mathrm{~d}$, $\left.J=2.3 \mathrm{~Hz}, 1 \mathrm{H}, \mathrm{H}_{3}\right), 4.10\left(\mathrm{~s}, 3 \mathrm{H}, \mathrm{CH}_{3}\right), 3.89\left(\mathrm{~s}, 3 \mathrm{H}, \mathrm{CH}_{3}\right) ;{ }^{13} \mathrm{C}$ NMR $\left(100 \mathrm{MHz}\right.$, DMSO- $\left.d_{6}\right) \delta$ $168.5(\mathrm{C}=\mathrm{O}), 165.7\left(\mathrm{C}_{4}\right), 164.6\left(\mathrm{C}_{2}\right), 159.9\left(\mathrm{C}_{6}\right), 139.6\left(\mathrm{C}_{1^{\prime}}\right), 134.8\left(\mathrm{C}_{4^{\prime}}\right), 132.0\left(\mathrm{C}_{2^{\prime}}\right), 125.4\left(\mathrm{C}_{5^{\prime}}\right)$, $124.8\left(\mathrm{C}_{3^{\prime}}\right), 124.8\left(\mathrm{C}_{6^{\prime}}\right), 97.2\left(\mathrm{C}_{1}\right), 94.7\left(\mathrm{C}_{5}\right), 91.0\left(\mathrm{C}_{3}\right), 56.5\left(\mathrm{CH}_{3}\right), 55.6\left(\mathrm{CH}_{3}\right) ; \mathrm{IR}\left(\mathrm{cm}^{-1}\right): 3284$, $1639,1575,1502,1390,1346,1276,1249,1157,1047$; MS (ESI) $m / z$ (\%): $319.1(100)[\mathrm{M}+\mathrm{H}]^{+}$; UPLC purity $=97 \%, t_{\mathrm{R}} 3.21 \mathrm{~min}$. 


\section{1,3-Dibenzyloxy-5-(2'-nitrophenoxy)benzene (7)}

A mixture of 3,5-dibenzyloxyphenol $3(1.00 \mathrm{~g}, 3.26 \mathrm{mmol})$ and potassium hydroxide $(0.18 \mathrm{~g}, 3.26 \mathrm{mmol})$ was heated to $120^{\circ} \mathrm{C}$ and stirred for $30 \mathrm{~min}$, and then 1-iodo-2nitrobenzene $(0.82 \mathrm{~g}, 3.26 \mathrm{mmol})$ and copper powder $(0.40 \mathrm{~g}, 6.25 \mathrm{mmol})$ were added, respectively. The resulting mixture was stirred at $170{ }^{\circ} \mathrm{C}$ for $2 \mathrm{~h}$ and then cooled down to room temperature. After the addition of water, the aqueous layer was extracted with ethyl acetate $(100 \mathrm{~mL})$ and washed with water $(2 \times 100 \mathrm{~mL})$. The organic layers were washed with brine, dried over sodium sulfate, filtered, and evaporated to dryness. The resulting oil was purified by silica gel column chromatography using cyclohexane/ethyl acetate $(8 / 2)$ as the eluent to give compound $7\left(1.02 \mathrm{~g}, 73 \%\right.$ yield) as a yellow powder. $R_{\mathrm{f}} 0.76$ (cyHex/AcOEt 6:4); Mp: $148-149{ }^{\circ} \mathrm{C} ;{ }^{1} \mathrm{H}$ NMR $\left(400 \mathrm{MHz}, \mathrm{CDCl}_{3}\right) \delta 7.80(\mathrm{dd}, J=8.1,1.7 \mathrm{~Hz}$, $\left.1 \mathrm{H}, \mathrm{H}_{3^{\prime}}\right), 7.35\left(\mathrm{ddd}, J=8.5,7.4,1.7 \mathrm{~Hz}, 1 \mathrm{H}, \mathrm{H}_{4^{\prime}}\right), 7.34-7.15\left(\mathrm{~m}, 10 \mathrm{H}, \mathrm{H}_{\mathrm{Ar}}\right), 7.12(\mathrm{ddd}, J=8.5$, 7.4, $\left.1.7 \mathrm{~Hz}, 1 \mathrm{H}, \mathrm{H}_{5^{\prime}}\right), 6.93\left(\mathrm{dd}, J=8.4,1.3 \mathrm{~Hz}, 1 \mathrm{H}, \mathrm{H}_{6^{\prime}}\right), 6.33\left(\mathrm{t}, J=2.2 \mathrm{~Hz}, 1 \mathrm{H}, \mathrm{H}_{2}\right), 6.17(\mathrm{~s}$, $\left.1 \mathrm{H}, \mathrm{H}_{4}\right), 6.17\left(\mathrm{~s}, 1 \mathrm{H}, \mathrm{H}_{6}\right), 4.86\left(\mathrm{~s}, 4 \mathrm{H}, 2 \mathrm{CH}_{2}\right) ;{ }^{13} \mathrm{C} \mathrm{NMR}\left(100 \mathrm{MHz}, \mathrm{CDCl}_{3}\right) \delta 160.9\left(2 \mathrm{C}_{1,3}\right)$, $157.7\left(\mathrm{C}_{5}\right), 150.0\left(\mathrm{C}_{1^{\prime}}\right), 141.5\left(\mathrm{C}_{2^{\prime}}\right), 136.4(2 \mathrm{C}), 134.2\left(\mathrm{C}_{4^{\prime}}\right), 128.6(2 \mathrm{C}), 128.6(2 \mathrm{C}), 128.1(1 \mathrm{C})$, $128.1(1 \mathrm{C}), 127.6(2 \mathrm{C}), 127.6(2 \mathrm{C}), 125.7\left(\mathrm{C}_{4^{\prime}}\right), 123.5\left(\mathrm{C}_{3^{\prime}}\right), 121.3\left(\mathrm{C}_{6^{\prime}}\right), 98.7\left(2 \mathrm{C}_{4,6}\right), 98.2\left(\mathrm{C}_{2}\right)$, $70.3\left(2 \mathrm{CH}_{2}\right)$; IR $\left(\mathrm{cm}^{-1}\right): 1589,1529,1450,1355,1236,1157,1128$; MS (ESI) $m / z(\%): 428.2$ (100) $[\mathrm{M}+\mathrm{H}]^{+}$; UPLC purity $=100 \%, t_{\mathrm{R}} 3.09 \mathrm{~min}$.

\section{1,3-Dimethoxy-5-(2'-nitrophenoxy)benzene (8)}

A mixture of 3,5-dimethoxyphenol $4(1.00 \mathrm{~g}, 6.5 \mathrm{mmol})$ and potassium hydroxide $(0.18 \mathrm{~g}, 6.5 \mathrm{mmol})$ was heated to $120{ }^{\circ} \mathrm{C}$ and stirred for $30 \mathrm{~min}$, and then 1-iodo-2nitrobenzene $(0.82 \mathrm{~g}, 6.5 \mathrm{mmol})$ and copper powder $(1.00 \mathrm{~g}, 15.6 \mathrm{mmol})$ were added, respectively. The resulting mixture was stirred at $170{ }^{\circ} \mathrm{C}$ for $2 \mathrm{~h}$ and then cooled down to room temperature. After the addition of water, the aqueous layer was extracted with ethyl acetate $(100 \mathrm{~mL})$. The organic layers were washed with brine, dried over sodium sulfate, filtered, and evaporated to dryness. The resulting oil was purified by silica gel column chromatography using cyclohexane/ethyl acetate (8/2) as eluent to give compound 8 ( $1.4 \mathrm{~g}$ $78 \%$ yield) as a yellow oil. $R_{\mathrm{f}} 0.42$ (cyHex/AcOEt 8:2); ${ }^{1} \mathrm{H}$ NMR (400 MHz, DMSO- $\left.d_{6}\right) \delta$ $8.07\left(\mathrm{dd}, J=8.2 \mathrm{~Hz}, 1.6 \mathrm{~Hz}, 1 \mathrm{H}, \mathrm{H}_{3^{\prime}}\right), 7.77-7.63\left(\mathrm{~m}, 1 \mathrm{H}, \mathrm{H}_{5^{\prime}}\right), 7.38\left(\mathrm{t}, J=7.8 \mathrm{~Hz}, 1 \mathrm{H}, \mathrm{H}_{4^{\prime}}\right), 7.21$ $\left(\mathrm{d}, J=8.4 \mathrm{~Hz}, 1 \mathrm{H}, \mathrm{H}_{6^{\prime}}\right), 6.38\left(\mathrm{t}, J=2.3 \mathrm{~Hz}, 1 \mathrm{H}, \mathrm{H}_{2}\right), 6.24\left(\mathrm{~s}, 2 \mathrm{H}, \mathrm{H}_{4,6}\right), 3.74\left(\mathrm{~s}, 6 \mathrm{H}, 2 \mathrm{CH}_{3}\right) ;{ }^{13} \mathrm{C}$ NMR (100 MHz, DMSO- $\left.d_{6}\right) \delta 161.4\left(2 \mathrm{C}_{1,3}\right), 157.2\left(\mathrm{C}_{5}\right), 148.8\left(\mathrm{C}_{1^{\prime}}\right), 141.0\left(\mathrm{C}_{2^{\prime}}\right), 134.9\left(\mathrm{C}_{4^{\prime}}\right)$, $125.5\left(\mathrm{C}_{5^{\prime}}\right), 124.2\left(\mathrm{C}_{3^{\prime}}\right), 120.9\left(\mathrm{C}_{6^{\prime}}\right), 97.1\left(2 \mathrm{C}_{4,6}\right), 96.4\left(\mathrm{C}_{2}\right), 55.4\left(2 \mathrm{CH}_{3}\right) ; \mathrm{IR}\left(\mathrm{cm}^{-1}\right): 1585,1523$, 1471, 1346, 1234, 1203, 1149, 1126, 1049; MS (ESI) $\mathrm{m} / z$ (\%): 276.1 (100) $[\mathrm{M}+\mathrm{H}]^{+}$; UPLC purity $=97 \%, t_{\mathrm{R}} 3.02 \mathrm{~min}$.

\section{2-(3',5'-Dibenzyloxyphenoxy)aniline (9)}

To a solution of 1,3-dibenzyloxy-5-(2'-nitrophenoxy)benzene 7 (100 mg, $0.23 \mathrm{mmol})$ in methanol $(10 \mathrm{~mL})$ at room temperature, saturated aqueous ammonium chloride $(5 \mathrm{~mL})$ and zinc dust (75 mg, $1.15 \mathrm{mmol}$ ) were added sequentially. After stirring for $30 \mathrm{~min}$ at room temperature, additional zinc was added $(75 \mathrm{mg}, 1.15 \mathrm{mmol})$ and the reaction mixture was refluxed for $2 \mathrm{~h}$. After the addition of water, the aqueous layer was extracted with dichloromethane $(3 \times 50 \mathrm{~mL})$. The combined organic extracts were dried over sodium sulfate and filtered. The solvent was evaporated in vacuo and the residue was purified by silica gel column chromatography using cyclohexane/ethyl acetate $(8 / 2)$ as the eluent to give compound $9\left(59 \mathrm{mg}, 65 \%\right.$ yield) as a brown powder. $R_{\mathrm{f}} 0.77$ (cyHex/AcOEt 6:4); Mp: $217-218{ }^{\circ} \mathrm{C} ;{ }^{1} \mathrm{H}$ NMR $\left(400 \mathrm{MHz}, \mathrm{CDCl}_{3}\right) \delta 7.37-7.12\left(\mathrm{~m}, 10 \mathrm{H}, \mathrm{H}_{\mathrm{Ar}}\right), 6.89(\mathrm{td}, J=7.6$, $\left.1.5 \mathrm{~Hz}, 1 \mathrm{H}, \mathrm{H}_{5}\right), 6.80\left(\mathrm{dd}, J=8.0,1.5 \mathrm{~Hz}, 1 \mathrm{H}, \mathrm{H}_{6}\right), 6.68\left(\mathrm{dt}, J=8.6,2.6 \mathrm{~Hz}, 1 \mathrm{H}, \mathrm{H}_{3}\right), 6.65(\mathrm{td}$, $\left.J=7.6,1.5 \mathrm{~Hz}, 1 \mathrm{H}, \mathrm{H}_{4}\right), 6.24\left(\mathrm{~s}, 1 \mathrm{H}, \mathrm{H}_{4^{\prime}}\right), 6.14\left(\mathrm{~s}, 2 \mathrm{H}, \mathrm{H}_{2^{\prime}, 6^{\prime}}\right), 4.87\left(\mathrm{~s}, 4 \mathrm{H}, 2 \mathrm{CH}_{2}\right) ;{ }^{13} \mathrm{C} \mathrm{NMR}$ $\left(100 \mathrm{MHz}, \mathrm{CDCl}_{3}\right) \delta 160.8\left(2 \mathrm{C}_{3^{\prime}, 5^{\prime}}\right), 159.5\left(\mathrm{C}_{1^{\prime}}\right), 142.4\left(\mathrm{C}_{2}\right), 138.9\left(\mathrm{C}_{1}\right), 136.6(2 \mathrm{C}), 128.6(4 \mathrm{C})$, $128.0(2 \mathrm{C}), 127.6(4 \mathrm{C}), 125.3\left(\mathrm{C}_{5}\right), 120.9\left(\mathrm{C}_{4}\right), 118.8\left(\mathrm{C}_{3}\right), 116.6\left(\mathrm{C}_{6}\right), 96.7\left(2 \mathrm{C}_{2^{\prime}, 6^{\prime}}\right), 96.4\left(\mathrm{C}_{4^{\prime}}\right)$, $70.1\left(2 \mathrm{CH}_{2}\right)$; IR ( $\left.\mathrm{cm}^{-1}\right): 2819,1597,1492,1450,1379,1253,1157,1126,1060 ;$ MS (ESI) $\mathrm{m} / \mathrm{z}$ (\%): $398.1(100)[\mathrm{M}+\mathrm{H}]^{+}$; UPLC purity $=100 \%, t_{\mathrm{R}} 3.12 \mathrm{~min}$. 
2-(3', $5^{\prime}$-Dimethoxyphenoxy)aniline (10)

To a solution of 1,3-dimethoxy-5-(2'-nitrophenoxy)benzene $8(250 \mathrm{mg}, 0.91 \mathrm{mmol})$ in methanol $(10 \mathrm{~mL})$ at room temperature, saturated aqueous ammonium chloride $(5 \mathrm{~mL})$ and zinc dust (295 mg, $4.54 \mathrm{mmol}$ ) were added sequentially. After stirring for $30 \mathrm{~min}$ at room temperature, additional zinc was added $(295 \mathrm{mg}, 4.54 \mathrm{mmol})$ and the reaction mixture was refluxed for $2 \mathrm{~h}$. After the addition of water, the aqueous layer was extracted with ethyl acetate $(100 \mathrm{~mL})$ and washed with water $(2 \times 50 \mathrm{~mL})$. The combined organic extracts were dried over sodium sulfate and filtered. The solvent was evaporated in vacuo and the residue was purified by silica gel column chromatography using cyclohexane/ethyl acetate $(6 / 4)$ as the eluent to give compound 7 (205 mg, $92 \%$ yield) as a brown oil. $R_{\mathrm{f}} 0.80$ (cyHex/AcOEt 6:4); ${ }^{1} \mathrm{H}$ NMR (400 MHz, $\left.\mathrm{CDCl}_{3}\right) \delta 6.89\left(\mathrm{td}, J=7.6,1.5 \mathrm{~Hz}, 1 \mathrm{H}, \mathrm{H}_{4}\right), 6.82$ $\left(\mathrm{dd}, J=8.0,1.4 \mathrm{~Hz}, 1 \mathrm{H}, \mathrm{H}_{3}\right), 6.71\left(\mathrm{dd}, J=7.9,1.6 \mathrm{~Hz}, 1 \mathrm{H}, \mathrm{H}_{6}\right), 6.62(\mathrm{td}, J=7.6,1.6 \mathrm{~Hz}, 1 \mathrm{H}$, $\left.\mathrm{H}_{5}\right), 6.09\left(\mathrm{t}, J=2.2 \mathrm{~Hz}, 1 \mathrm{H}, \mathrm{H}_{4^{\prime}}\right), 6.06\left(\mathrm{~d}, J=2.3 \mathrm{~Hz}, 1 \mathrm{H}, 2 \mathrm{H}_{2^{\prime}}\right), 6.05\left(\mathrm{~d}, J=2.3 \mathrm{~Hz}, 2 \mathrm{H}, 2 \mathrm{H}_{6^{\prime}}\right)$, $3.64\left(\mathrm{~s}, 3 \mathrm{H}, \mathrm{CH}_{3}\right), 3.60\left(\mathrm{~s}, 3 \mathrm{H}, \mathrm{CH}_{3}\right) ;{ }^{13} \mathrm{C}$ NMR $\left(100 \mathrm{MHz}, \mathrm{DMSO}-d_{6}\right) \delta 161.2\left(2 \mathrm{C}_{3^{\prime}, 5^{\prime}}\right), 159.4$ $\left(\mathrm{C}_{1^{\prime}}\right), 141.0\left(\mathrm{C}_{2}\right), 140.4\left(\mathrm{C}_{1}\right), 125.1\left(\mathrm{C}_{4}\right), 120.7\left(\mathrm{C}_{5}\right), 116.4\left(\mathrm{C}_{3}\right), 115.8\left(\mathrm{C}_{6}\right), 95.1\left(2 \mathrm{C}_{2^{\prime}, 6^{\prime}}\right), 94.0$ $\left(\mathrm{C}_{4^{\prime}}\right), 55.0\left(2 \mathrm{CH}_{3}\right)$; IR $\left(\mathrm{cm}^{-1}\right): 3373,2964,1697,1595,1500,1473,1458,1427,1301,1269,1197$, 1149, 1130, 1051; MS (ESI) $\mathrm{m} / z$ (\%): $246.1(100)[\mathrm{M}+\mathrm{H}]^{+}$; UPLC purity $=100 \%, t_{\mathrm{R}} 2.51 \mathrm{~min}$.

\section{1,3-Dimethoxy-6-nitrodibenzo[b,d]furan (13)}

1,3-Dimethoxy-5-(2'-nitrophenoxy)benzene $8(1.00 \mathrm{~g}, 3.6 \mathrm{mmol})$ was dissolved in warm pivalic acid $\left(50^{\circ} \mathrm{C}, 60 \mathrm{~g}\right)$. Silver acetate $(1.20 \mathrm{~g}, 7.2 \mathrm{mmol})$ and palladium (II) acetate $\left(40 \mathrm{mg}, 0.18 \mathrm{mmol}\right.$ ) were added, and the reaction mixture was properly stirred at $130{ }^{\circ} \mathrm{C}$ for $4 \mathrm{~h}$. After cooling to room temperature and the addition of water $(100 \mathrm{~mL})$, the aqueous layer was extracted with ethyl acetate $(100 \mathrm{~mL})$. The organic layers were washed with brine, dried over sodium sulfate, filtered, and evaporated to dryness. The resulting oil was purified by silica gel column chromatography using cyclohexane/ethyl acetate $(8 / 2)$ as the eluent to give compound $13\left(0.71 \mathrm{~g}, 72 \%\right.$ yield) as a yellow powder. $R_{\mathrm{f}} 0.64$ (cyHex/AcOEt 6:4); Mp: $212-213^{\circ} \mathrm{C}^{1}{ }^{1} \mathrm{H}$ NMR (400 MHz, DMSO- $\left.d_{6}\right) \delta 8.27$ (dd, $J=7.6 \mathrm{~Hz}, 1.1 \mathrm{~Hz}, 1 \mathrm{H}$, $\left.\mathrm{H}_{9}\right), 8.18\left(\mathrm{dd}, J=8.3,1.1 \mathrm{~Hz}, 1 \mathrm{H}, \mathrm{H}_{7}\right), 7.55\left(\mathrm{t}, J=8.0 \mathrm{~Hz}, 1 \mathrm{H}, \mathrm{H}_{8}\right), 7.13(\mathrm{~d}, J=1.8 \mathrm{~Hz}, 1 \mathrm{H}$, $\left.\mathrm{H}_{4}\right), 6.66\left(\mathrm{~d}, J=1.8 \mathrm{~Hz}, 1 \mathrm{H}, \mathrm{H}_{2}\right), 4.03\left(\mathrm{~s}, 3 \mathrm{H}, \mathrm{CH}_{3}\right), 3.90\left(\mathrm{~s}, 3 \mathrm{H}, \mathrm{CH}_{3}\right) ;{ }^{13} \mathrm{C} \mathrm{NMR}(100 \mathrm{MHz}$, DMSO- $\left.d_{6}\right) \delta 162.2\left(\mathrm{C}_{3}\right), 158.2\left(\mathrm{C}_{1}\right), 155.5(\mathrm{C}), 147.1(\mathrm{C}), 132.9\left(\mathrm{C}_{6}\right), 127.6\left(\mathrm{C}_{8}\right), 126.9(\mathrm{C}), 123.7$ $\left(\mathrm{C}_{9}\right), 120.5\left(\mathrm{C}_{7}\right), 104.4(\mathrm{C}), 95.3\left(\mathrm{C}_{2}\right), 89.3\left(\mathrm{C}_{4}\right), 56.1\left(\mathrm{CH}_{3}\right), 56.1\left(\mathrm{CH}_{3}\right) ; \mathrm{IR}\left(\mathrm{cm}^{-1}\right)$ : 3088, 2933, $1637,1602,1531,1502,1450,1417,1344,1219,1145,1095 ;$ MS (ESI) $m / z$ (\%): 274.1 (100) [M + $\mathrm{H}]^{+}$; UPLC purity $=99 \%, t_{\mathrm{R}} 3.16 \mathrm{~min}$.

\section{1,3-Dimethoxy-6-nitrodibenzo[b,d]furan-4-carboxamide (14)}

To a stirred suspension of 1,3-dimethoxy-6-nitrodibenzo[b,d]furan $\mathbf{1 3}(1.00 \mathrm{~g}, 3.7 \mathrm{mmol})$ in acetonitrile $(20 \mathrm{~mL})$ at $0{ }^{\circ} \mathrm{C}$ under argon, chlorosulfonyl isocyanate $(0.64 \mathrm{~mL}, 7.4 \mathrm{mmol})$ was added. The mixture was maintained at room temperature for $12 \mathrm{~h}$ and then the reaction mixture was quenched with $\mathrm{HCl} 5 \mathrm{M}(20 \mathrm{~mL})$. After $6 \mathrm{~h}$ at room temperature, the reaction was diluted with water $(100 \mathrm{~mL})$ and extracted with ethyl acetate $(100 \mathrm{~mL})$. The combined organic extracts were dried over sodium sulfate and filtered. The solvent was evaporated in vacuo and the residue was purified by silica gel column chromatography using cyclohexane/ethyl acetate (6/4) as the eluent to give compound $\mathbf{1 4}(0.61 \mathrm{~g}, 53 \%$ yield) as a yellow powder. $R_{\mathrm{f}} 0.63\left(\mathrm{CH}_{2} \mathrm{Cl}_{2} / \mathrm{MeOH} 9: 1\right)$; Mp: $298-299{ }^{\circ} \mathrm{C} ;{ }^{1} \mathrm{H} \mathrm{NMR}(400 \mathrm{MHz}$, DMSO- $\left.d_{6}\right) \delta 8.32\left(\mathrm{~d}, J=7.6 \mathrm{~Hz}, 1 \mathrm{H}, \mathrm{H}_{9}\right), 8.20\left(\mathrm{~d}, J=8.3 \mathrm{~Hz}, 1 \mathrm{H}, \mathrm{H}_{7}\right), 7.77(\mathrm{~s}, 1 \mathrm{H}, \mathrm{NH})$, 7.67-7.54 (m, 2H, NH, $\left.\mathrm{H}_{8}\right), 6.82\left(\mathrm{~s}, 1 \mathrm{H}, \mathrm{H}_{2}\right), 4.13\left(\mathrm{~s}, 3 \mathrm{H}, \mathrm{CH}_{3}\right), 3.98\left(\mathrm{~s}, 3 \mathrm{H}, \mathrm{CH}_{3}\right) ;{ }^{13} \mathrm{C} \mathrm{NMR}$ $\left(100 \mathrm{MHz}, \mathrm{DMSO}-d_{6}\right) \delta 163.7(\mathrm{C}=\mathrm{O}), 158.7\left(\mathrm{C}_{1}\right), 155.8\left(\mathrm{C}_{3}\right), 154.8(\mathrm{C}), 147.1(\mathrm{C}), 133.0\left(\mathrm{C}_{6}\right)$, $127.7\left(\mathrm{C}_{8}\right), 126.6(\mathrm{C}), 123.8\left(\mathrm{C}_{9}\right), 120.9\left(\mathrm{C}_{7}\right), 105.1(\mathrm{C}), 104.3\left(\mathrm{C}_{4}\right), 92.2\left(\mathrm{C}_{2}\right), 56.8\left(\mathrm{CH}_{3}\right), 56.4$ $\left(\mathrm{CH}_{3}\right)$; IR $\left(\mathrm{cm}^{-1}\right): 3136,3091,2846,2140,1977,1643,1606,1521,1427,1355,1323,1217,108$; MS (ESI) $m / z$ (\%): $317.2(100)[\mathrm{M}+\mathrm{H}]^{+}$; UPLC purity $=99 \%, t_{\mathrm{R}} 2.24 \mathrm{~min}$; HRMS (TOF MS ES+): calcd. for $\mathrm{C}_{15} \mathrm{H}_{13} \mathrm{~N}_{2} \mathrm{O}_{6}[\mathrm{M}+\mathrm{H}]^{+}$317.076813, found: 317.07664. 


\section{1,3-Dihydroxy-6-nitrodibenzo[b,d]furan-4-carboxamide (15)}

A mixture of 1,3-dimethoxy-6-nitrodibenzo[ $b, d]$ furan-4-carboxamide 14 (50 mg, $0.16 \mathrm{mmol}$ ) in pyridine hydrochloride (3g) was irradiated using microwave heating at $200{ }^{\circ} \mathrm{C}$ for $15 \mathrm{~min}$. After the addition of water, the aqueous layer was extracted with ethyl acetate $(50 \mathrm{~mL})$ and the resulting organic layer was washed with water $(2 \times 50 \mathrm{~mL})$. The combined organic extracts were dried over sodium sulfate and filtered. The solvent was evaporated in vacuo and the residue was purified by silica gel column chromatography using cyclohexane/ethyl acetate (6/4) as the eluent to give compound $15\left(23 \mathrm{mg}, 51 \%\right.$ yield) as a yellow powder. $R_{\mathrm{f}} 0.67\left(\mathrm{CH}_{2} \mathrm{Cl}_{2} / \mathrm{MeOH}\right.$ 9:1); $\mathrm{Mp}>300{ }^{\circ} \mathrm{C} ;{ }^{1} \mathrm{H}$ NMR (400 MHz, DMSO-d 6 ) $\delta 13.80(\mathrm{~s}, 1 \mathrm{H}, \mathrm{OH}), 11.77(\mathrm{~s}, 1 \mathrm{H}, \mathrm{OH}), 8.54(\mathrm{~s}$, $1 \mathrm{H}, \mathrm{NH}), 8.42-8.07\left(\mathrm{~m}, 2 \mathrm{H}, \mathrm{NH}, \mathrm{H}_{9}\right), 7.75-7.36\left(\mathrm{~m}, 2 \mathrm{H}, \mathrm{H}_{8,7}\right), 6.39\left(\mathrm{~s}, 1 \mathrm{H}, \mathrm{H}_{2}\right) ;{ }^{13} \mathrm{C}$ NMR $(100$ MHz, DMSO- $\left.d_{6}\right) \delta 169.6(\mathrm{C}=\mathrm{O}), 165.1\left(\mathrm{C}_{1}\right), 157.9\left(\mathrm{C}_{3}\right), 155.7(\mathrm{C}), 146.3(\mathrm{C}), 133.0\left(\mathrm{C}_{6}\right), 127.7\left(\mathrm{C}_{8}\right)$, $126.5(\mathrm{C}), 124.5\left(\mathrm{C}_{9}\right), 120.3\left(\mathrm{C}_{7}\right), 103.1\left(\mathrm{C}_{4}\right), 98.9\left(\mathrm{C}_{2}\right), 92.7(\mathrm{C})$; $\mathrm{IR}\left(\mathrm{cm}^{-1}\right)$ : 3458, 3196, 1654, 1629, 1608, 1517, 1477, 1440, 1404, 1359, 1323, 1251, 1220, 1195, 1120, 1082; MS (ESI) $m / z$ (\%): 289.1 (100) $[\mathrm{M}+\mathrm{H}]^{+}$; UPLC purity $=99 \%$, $t_{\mathrm{R}} 2.37 \mathrm{~min}$; HRMS (TOF MS ES+): calcd. for $\mathrm{C}_{13} \mathrm{H}_{9} \mathrm{~N}_{2} \mathrm{O}_{6}$ $[\mathrm{M}+\mathrm{H}]^{+}$289.045512, found: 289.04558 .

\section{6-Amino-1,3-dihydroxydibenzo[ $[b, d]$ furan-4-carboxamide (16)}

To a solution of 1,3-dihydroxy-6-nitrodibenzo[ $[b, d]$ furan-4-carboxamide 15 (50 mg, $0.17 \mathrm{mmol})$ in methanol $(10 \mathrm{~mL})$ at room temperature, saturated aqueous ammonium chloride $(5 \mathrm{~mL})$ and zinc dust ( $55 \mathrm{mg}, 0.85 \mathrm{mmol}$ ) were added sequentially. After stirring for $30 \mathrm{~min}$ at room temperature, additional zinc was added $(55 \mathrm{mg}, 0.85 \mathrm{mmol}$ ) and the reaction mixture was refluxed for $2 \mathrm{~h}$. After the addition of water, the aqueous layer was extracted with ethyl acetate $(100 \mathrm{~mL})$ and the resulting organic layer was washed with water $(2 \times 50 \mathrm{~mL})$. The combined organic extracts were dried over sodium sulfate and filtered. The solvent was evaporated in vacuo and the residue was purified by silica gel column chromatography using cyclohexane/ethyl acetate (6/4) as the eluent to give compound 16 (28 $\mathrm{mg}, 62 \%$ yield) as a brown powder. $R_{\mathrm{f}} 0.34\left(\mathrm{CH}_{2} \mathrm{Cl}_{2} / \mathrm{MeOH}\right.$ 9:1); $\mathrm{Mp}$ : 292-293 ${ }^{\circ} \mathrm{C} ;{ }^{1} \mathrm{H}$ NMR $\left(400 \mathrm{MHz}\right.$, DMSO-d $\left.d_{6}\right) \delta 14.19(\mathrm{~s}, 1 \mathrm{H}, \mathrm{OH}), 11.12(\mathrm{~s}, 1 \mathrm{H}, \mathrm{OH}), 8.19(\mathrm{~s}, 1 \mathrm{H}$, $\left.\mathrm{CONH}_{2}\right), 8.11\left(\mathrm{~s}, 1 \mathrm{H}, \mathrm{CONH}_{2}\right), 7.12\left(\mathrm{~d}, J=7.5 \mathrm{~Hz}, 1 \mathrm{H}, \mathrm{H}_{9}\right), 7.03\left(\mathrm{t}, J=7.6 \mathrm{~Hz}, 1 \mathrm{H}, \mathrm{H}_{8}\right), 6.63(\mathrm{~d}$, $\left.J=7.8 \mathrm{~Hz}, 1 \mathrm{H}, \mathrm{H}_{7}\right), 6.25\left(\mathrm{~s}, 1 \mathrm{H}, \mathrm{H}_{2}\right) ;{ }^{13} \mathrm{C} \mathrm{NMR}(100 \mathrm{MHz}, \mathrm{DMSO}) \delta 170.2(\mathrm{C}=\mathrm{O}), 164.2\left(\mathrm{C}_{1}\right), 157.7$ $\left(\mathrm{C}_{3}\right), 154.8(\mathrm{C}), 142.2(\mathrm{C}), 133.3\left(\mathrm{C}_{6}\right), 124.4\left(\mathrm{C}_{8}\right), 123.0(\mathrm{C}), 110.2\left(\mathrm{C}_{9}\right), 108.1\left(\mathrm{C}_{7}\right), 105.3\left(\mathrm{C}_{4}\right), 97.8\left(\mathrm{C}_{2}\right)$, 92.5 (C); IR ( $\left.\mathrm{cm}^{-1}\right): 3294,3192,1492,1427,1261,1190,1085,1053 ;$ MS (ESI) $\mathrm{m} / z$ (\%): 259.2 (100) [M $+\mathrm{H}]^{+}$; UPLC purity $=99 \%, t_{\mathrm{R}} 1.67 \mathrm{~min}$; HRMS (TOF MS ES+): calcd. for $\mathrm{C}_{13} \mathrm{H}_{11} \mathrm{~N}_{2} \mathrm{O}_{4}[\mathrm{M}+\mathrm{H}]^{+}$ 259.071333, found: 259.07147 .

\section{1,3-Dihydroxydibenzo[b, $d]$ furan-4-carboxamide (17)}

Method A: To a solution of 6-amino-1,3-dihydroxydibenzo[ $[b, d]$ furan-4-carboxamide $16(100 \mathrm{mg}, 0.38 \mathrm{mmol})$ in ethanol $(10 \mathrm{~mL})$ at room temperature, sulfuric acid $(25 \%, 40 \mathrm{~mL})$ was added under warming. The mixture was cooled to $0{ }^{\circ} \mathrm{C}$, and a solution of sodium nitrite ( $54 \mathrm{mg}, 0.76 \mathrm{mmol}$ ) in $5 \mathrm{~mL}$ of water was added dropwise with stirring for $30 \mathrm{~min}$. Afterwards, the reaction mixture was stirred for $45 \mathrm{~min}$ at $80{ }^{\circ} \mathrm{C}$ and then the reaction was quenched with water. The aqueous layer was extracted with ethyl acetate $(100 \mathrm{~mL})$ and the organic layer was washed with brine, dried over sodium sulfate, and filtered. The solvent was evaporated in vacuo and the residue was purified by silica gel column chromatography using cyclohexane/ethyl acetate (6/4) as the eluent to give compound $\mathbf{1 7}$ (49 $\mathrm{mg}, 52 \%$ yield) as a brown powder.

Method B: A mixture of 1,3-dimethoxydibenzo[b,d]furan-4-carboxamide 19 (see below) $(100 \mathrm{mg}, 0.37 \mathrm{mmol})$ in pyridine hydrochloride $(3 \mathrm{~g})$ was irradiated using microwave heating at $200{ }^{\circ} \mathrm{C}$ for $15 \mathrm{~min}$. After the addition of water, the aqueous layer was extracted with ethyl acetate $(50 \mathrm{~mL})$ and the resulting organic layer was washed with water $(2 \times 50 \mathrm{~mL})$. The combined organic extracts were dried over sodium sulfate and filtered. The solvent was evaporated in vacuo and the residue was purified by silica gel column chromatography using cyclohexane/ethyl acetate (6/4) as the eluent to give compound 17 (43 mg, 48\% yield) as a brown powder. 
$R_{\mathrm{f}} 0.20\left(\mathrm{CH}_{2} \mathrm{Cl}_{2}\right)$; Mp: $219-220{ }^{\circ} \mathrm{C} ;{ }^{1} \mathrm{H}$ NMR (400 MHz, DMSO-d $\left.d_{6}\right) \delta 13.93(\mathrm{~s}, 1 \mathrm{H}, \mathrm{OH}), 11.34$ $(\mathrm{s}, 1 \mathrm{H}, \mathrm{OH}), 8.28\left(\mathrm{~s}, 1 \mathrm{H}, \mathrm{CONH}_{2}\right), 8.03-7.88\left(\mathrm{~m}, 1 \mathrm{H}, \mathrm{H}_{9}\right), 7.85\left(\mathrm{~s}, 1 \mathrm{H}, \mathrm{CONH}_{2}\right), 7.77-7.65(\mathrm{~m}, 1 \mathrm{H}$, $\left.\mathrm{H}_{6}\right), 7.57-7.25\left(\mathrm{~m}, 2 \mathrm{H}, \mathrm{H}_{7,8}\right), 6.31\left(\mathrm{~s}, 1 \mathrm{H}, \mathrm{H}_{2}\right) ;{ }^{13} \mathrm{C}$ NMR $\left(100 \mathrm{MHz}, \mathrm{DMSO}-d_{6}\right) \delta 170.0(\mathrm{C}=\mathrm{O}), 164.3$ $\left(\mathrm{C}_{1}\right), 157.7\left(\mathrm{C}_{3}\right), 155.2(\mathrm{C}), 154.2(\mathrm{C}), 124.8\left(\mathrm{C}_{7}\right), 123.7\left(\mathrm{C}_{8}\right), 122.7(\mathrm{C}), 121.0\left(\mathrm{C}_{9}\right), 111.3\left(\mathrm{C}_{6}\right), 104.4$ $\left(C_{4}\right), 98.0\left(C_{2}\right), 92.6(C)$; IR $\left(\mathrm{cm}^{-1}\right): 3456,3132,1604,1446,1409,1348,1315,1286,1230,1195,1103$, 1053; MS (ESI) $m / z$ (\%): $244.1(100)[\mathrm{M}+\mathrm{H}]^{+}$; UPLC purity $=98 \%, t_{\mathrm{R}} 2.14 \mathrm{~min}$; HRMS (TOF MS $\mathrm{ES}+$ ): calcd. for $\mathrm{C}_{13} \mathrm{H}_{10} \mathrm{NO}_{4}[\mathrm{M}+\mathrm{H}]^{+} 244.060434$, found: 244.06010 .

6-Amino-1,3-dimethoxydibenzo[ $b, d]$ furan-4-carboxamide (18)

To a solution of 1,3-dimethoxy-6-nitrodibenzo[ $b, d]$ furan-4-carboxamide 14 (50 mg, $0.16 \mathrm{mmol})$ in methanol $(10 \mathrm{~mL})$ at room temperature, saturated aqueous ammonium chloride $(5 \mathrm{~mL})$ and zinc dust (55 mg, $0.85 \mathrm{mmol}$ ) were added sequentially. After stirring for $30 \mathrm{~min}$ at room temperature, additional zinc was added (55 mg, $0.85 \mathrm{mmol}$ ) and the reaction mixture was refluxed for $2 \mathrm{~h}$. After the addition of water, the aqueous layer was extracted with ethyl acetate $(100 \mathrm{~mL})$ and the resulting organic layer was washed with water $(2 \times 50 \mathrm{~mL})$. The combined organic extracts were dried over sodium sulfate and filtered. The solvent was evaporated in vacuo and the residue was purified by silica gel column chromatography using cyclohexane/ethyl acetate (6/4) as eluent to give compound 18 (22 mg, $49 \%$ yield) as a brown powder. $R_{\mathrm{f}} 0.52\left(\mathrm{CH}_{2} \mathrm{Cl}_{2} / \mathrm{MeOH} 9: 1\right) ; \mathrm{Mp}$ : 293-294 ${ }^{\circ} \mathrm{C} ;{ }^{1} \mathrm{H}$ NMR (400 MHz, DMSO- $\left.d_{6}\right) \delta 7.67(\mathrm{~s}, 1 \mathrm{H}, \mathrm{NH}), 7.44(\mathrm{~s}, 1 \mathrm{H}, \mathrm{NH}), 7.17(\mathrm{~d}, J=7.5$ $\left.\mathrm{Hz}, 1 \mathrm{H}, \mathrm{H}_{9}\right), 7.03\left(\mathrm{t}, J=7.7 \mathrm{~Hz}, 1 \mathrm{H}, \mathrm{H}_{8}\right), 6.70\left(\mathrm{~d}, J=5.9 \mathrm{~Hz}, 1 \mathrm{H}, \mathrm{H}_{7}\right), 6.68\left(\mathrm{~s}, 1 \mathrm{H}, \mathrm{H}_{2}\right), 5.25(\mathrm{~s}, 2 \mathrm{H}$, $\left.\mathrm{NH}_{2}\right), 4.05\left(\mathrm{~s}, 3 \mathrm{H}, \mathrm{CH}_{3}\right), 3.93\left(\mathrm{~s}, 3 \mathrm{H}, \mathrm{CH}_{3}\right) ;{ }^{13} \mathrm{C}$ NMR $\left(100 \mathrm{MHz}, \mathrm{DMSO}-d_{6}\right) \delta 164.6(\mathrm{C}=\mathrm{O}), 157.2$ $\left(\mathrm{C}_{1}\right), 155.5\left(\mathrm{C}_{3}\right), 153.9(\mathrm{C}), 142.9(\mathrm{C}), 133.1\left(\mathrm{C}_{6}\right), 123.7\left(\mathrm{C}_{8}\right), 122.7(\mathrm{C}), 111.2\left(\mathrm{C}_{9}\right), 109.1\left(\mathrm{C}_{7}\right), 107.0$ $\left(\mathrm{C}_{4}\right), 104.8(\mathrm{C}), 90.9\left(\mathrm{C}_{2}\right), 56.6\left(\mathrm{CH}_{3}\right), 56.0\left(\mathrm{CH}_{3}\right) ; \mathrm{IR}\left(\mathrm{cm}^{-1}\right): 3180,1643,1604,1492,1413,1319,1211$, 1101; MS (ESI) $m / z(\%): 287.2(100)[\mathrm{M}+\mathrm{H}]^{+}$; UPLC purity $=99 \%, t_{\mathrm{R}} 1.83 \mathrm{~min}$; HRMS (TOF MS $\mathrm{ES}+$ ): calcd. for $\mathrm{C}_{15} \mathrm{H}_{15} \mathrm{~N}_{2} \mathrm{O}_{4}[\mathrm{M}+\mathrm{H}]^{+} 287.102633$, found: 287.10220 .

\section{1,3-Dimethoxydibenzo[ $b, d]$ furan-4-carboxamide (19)}

Method A: To a solution of 6-amino-1,3-dimethoxydibenzo[ $b, d]$ furan-4-carboxamide $18(50 \mathrm{mg}, 0.17 \mathrm{mmol})$ in ethanol $(10 \mathrm{~mL})$ at room temperature, sulfuric acid $(25 \%, 20 \mathrm{~mL})$ was added under warming. The mixture was cooled to $0{ }^{\circ} \mathrm{C}$, and a solution of sodium nitrite $(24 \mathrm{mg}, 0.34 \mathrm{mmol})$ in $5 \mathrm{~mL}$ of water was added dropwise with stirring for $30 \mathrm{~min}$. The reaction mixture was stirred for $45 \mathrm{~min}$ at $80{ }^{\circ} \mathrm{C}$ and then the reaction was quenched with water. The aqueous layer was extracted with ethyl acetate $(100 \mathrm{~mL})$ and the organic layer was washed with brine, dried over sodium sulfate, and filtered. The solvent was evaporated in vacuo and the residue was purified by silica gel column chromatography using cyclohexane/ethyl acetate (6/4) as the eluent to give compound 19 (22 mg, 46\% yield) as a pale brown powder.

Method B: A mixture of 2'-fluoro-2-hydroxy-4,6-dimethoxybiphenyl-3-carboxamide 49 (see below) (50 mg, $0.17 \mathrm{mmol}$ ) and cesium carbonate $(166 \mathrm{mg}, 0.51 \mathrm{mmol})$ in acetonitrile was irradiated using microwave $(80 \mathrm{~W})$ heating at $150{ }^{\circ} \mathrm{C}$ for $1 \mathrm{~h}$. Ethyl acetate $(50 \mathrm{~mL})$ was added to the mixture and the organic layer was washed with water $(2 \times 50 \mathrm{~mL})$, dried over sodium sulfate, and filtered. The solvent was evaporated in vacuo and the residue was crystallized from diisopropyl ether to furnish the title compound $\mathbf{1 9}$ as a pale brown solid (28 $\mathrm{mg}, 61 \%$ )

$R_{\mathrm{f}} 0.41\left(\mathrm{CH}_{2} \mathrm{Cl}_{2} / \mathrm{MeOH} 9: 1\right) ; \mathrm{Mp}: 296-297{ }^{\circ} \mathrm{C} ;{ }^{1} \mathrm{H}$ NMR $\left(400 \mathrm{MHz}, \mathrm{DMSO}-d_{6}\right) \delta 7.95$ $\left(\mathrm{dd}, J=7.5,1.5 \mathrm{~Hz}, 1 \mathrm{H}, \mathrm{H}_{9}\right), 7.69(\mathrm{~s}, 1 \mathrm{H}, \mathrm{NH}), 7.65\left(\mathrm{~d}, J=8.0 \mathrm{~Hz}, 1 \mathrm{H}, \mathrm{H}_{6}\right), 7.51(\mathrm{~s}, 1 \mathrm{H}, \mathrm{NH})$, $7.38\left(\mathrm{~m}, 2 \mathrm{H}, \mathrm{H}_{7,8}\right), 6.72\left(\mathrm{~s}, 1 \mathrm{H}, \mathrm{H}_{2}\right), 4.09\left(\mathrm{~s}, 3 \mathrm{H}, \mathrm{CH}_{3}\right), 3.95\left(\mathrm{~s}, 3 \mathrm{H}, \mathrm{CH}_{3}\right) ;{ }^{13} \mathrm{C} \mathrm{NMR}(100 \mathrm{MHz}$, DMSO-d $\left.d_{6}\right) \delta 164.5(\mathrm{C}=\mathrm{O}), 157.6\left(\mathrm{C}_{1}\right), 155.7\left(\mathrm{C}_{3}\right), 154.8(\mathrm{C}), 154.4(\mathrm{C}), 125.5\left(\mathrm{C}_{7}\right), 123.2\left(\mathrm{C}_{8}\right)$, $122.5(\mathrm{C}), 121.3\left(\mathrm{C}_{9}\right), 110.9\left(\mathrm{C}_{6}\right), 105.9\left(\mathrm{C}_{4}\right), 104.7(\mathrm{C}), 91.1\left(\mathrm{C}_{2}\right), 56.7\left(\mathrm{CH}_{3}\right), 56.1\left(\mathrm{CH}_{3}\right)$; IR $\left(\mathrm{cm}^{-1}\right): 3381,3201,2968,1641,1602,1452,1421,1321,1213$; MS (ESI) $m / z$ (\%): 272.2 (100) $[\mathrm{M}+\mathrm{H}]^{+}$; UPLC purity $=99 \%, t_{\mathrm{R}} 2.21 \mathrm{~min}$; HRMS (TOF MS ES+): calcd. for $\mathrm{C}_{15} \mathrm{H}_{14} \mathrm{NO}_{4}$ $[\mathrm{M}+\mathrm{H}]^{+}$272.091734, found: 272.09149 .

Access to dibenzofuran derivatives 38-47 was achieved by intramolecular C-C bond formation from diaryl ethers. 


\subsubsection{Preparation of Starting Iodo-Aryl Derivatives 21-24}

3-Iodophenyl acetate (21)

Acetic anhydride $(4.3 \mathrm{~mL}, 45.47 \mathrm{mmol})$ was added to a solution of 3-iodophenol 20 $(1.00 \mathrm{~g}, 4.55 \mathrm{mmol})$ in pyridine $(5 \mathrm{~mL})$. After stirring at $130{ }^{\circ} \mathrm{C}$ for $2 \mathrm{~h}$, the reaction was concentrated in vacuo and the residue was purified by silica gel column chromatography using cyclohexane/ethyl acetate (8/2) to give compound $21(1.06 \mathrm{~g}, 90 \%$ yield) as a white solid. $R_{\mathrm{f}} 0.65$ (cyHex/AcOEt 8:2); Mp: 33-34 ${ }^{\circ} \mathrm{C}$ (lit. 32.4-34.6 ${ }^{\circ} \mathrm{C}$ ) [59]; ${ }^{1} \mathrm{H}$ NMR (400 MHz, $\left.\mathrm{CDCl}_{3}\right) \delta 7.49(\mathrm{dt}, J=7.2,1.7 \mathrm{~Hz}, 1 \mathrm{H}), 7.45-7.28(\mathrm{~m}, 1 \mathrm{H}), 7.11-6.88(\mathrm{~m}, 2 \mathrm{H}), 2.21(\mathrm{~s}, 3 \mathrm{H}$, $\left.\mathrm{CH}_{3}\right) ;{ }^{13} \mathrm{C}$ NMR $\left(100 \mathrm{MHz}, \mathrm{CDCl}_{3}\right) \delta 168.9(\mathrm{C}=\mathrm{O}), 150.9\left(\mathrm{C}_{1}\right), 134.9\left(\mathrm{C}_{4}\right), 130.8\left(\mathrm{C}_{5}\right), 130.6$ $\left(\mathrm{C}_{2}\right), 121.1\left(\mathrm{C}_{6}\right), 93.5\left(\mathrm{C}_{3}\right), 21.0\left(\mathrm{CH}_{3}\right)$; IR $\left(\mathrm{cm}^{-1}\right): 1747,1735,1573,1365,1201,1192,1072$, 1031, 1001, 981; MS (ESI) $m / z(\%): 263.1(100)[\mathrm{M}+\mathrm{H}]^{+}$; UPLC purity $=100 \%, t_{\mathrm{R}} 2.60 \mathrm{~min}$. Literature spectroscopic data Reference [59].

\section{1-(2-Hydroxy-4-iodophenyl)ethanone (22)}

3-Iodophenyl acetate 21 ( $250 \mathrm{mg}, 0.95 \mathrm{mmol})$ was dissolved in boron trifluoride acetic acid complex $(4 \mathrm{~mL})$. The mixture was stirred at $180{ }^{\circ} \mathrm{C}$ for $12 \mathrm{~h}$. The reaction medium was allowed to cool and then was diluted in dichloromethane $(20 \mathrm{~mL})$. Then, $5 \mathrm{M}$ Sodium hydroxide aqueous solution was added $(20 \mathrm{~mL})$. The aqueous layer was extracted with dichloromethane $(100 \mathrm{~mL})$ and washed with distilled water $(100 \mathrm{~mL})$. The aqueous layers were acidified with $5 \mathrm{M}$ hydrochloric acid solution $(20 \mathrm{~mL})$ and extracted with dichloromethane. The combined organic layers were dried over sodium sulfate and filtered. The solvent was evaporated in vacuo and the residue was purified by silica gel column chromatography using cyclohexane/ethyl acetate $(8 / 2)$ as the eluent to give compound $22\left(219 \mathrm{mg}, 88 \%\right.$ yield) as a beige powder. $R_{\mathrm{f}} 0.68$ (cyHex/AcOEt 8:2); Mp: $52-53{ }^{\circ} \mathrm{C}$ (lit. 51.5-52 $\left.{ }^{\circ} \mathrm{C}\right)[59] ;{ }^{1} \mathrm{H}$ NMR $\left(400 \mathrm{MHz}, \mathrm{CDCl}_{3}\right) \delta 12.18(\mathrm{~s}, 1 \mathrm{H}, \mathrm{OH}), 7.50-7.24(\mathrm{~m}, 2 \mathrm{H})$, 7.27-7.07 (m, 1H), $2.53\left(\mathrm{~s}, 3 \mathrm{H}, \mathrm{CH}_{3}\right) ;{ }^{13} \mathrm{C}$ NMR $\left(100 \mathrm{MHz}, \mathrm{CDCl}_{3}\right) \delta 204.1(\mathrm{C}=\mathrm{O}), 162.2\left(\mathrm{C}_{2}\right)$, $131.2\left(\mathrm{C}_{5}\right), 128.3\left(\mathrm{C}_{6}\right), 127.8\left(\mathrm{C}_{3}\right), 119.0\left(\mathrm{C}_{1}\right), 103.7\left(\mathrm{C}_{4}\right), 26.5\left(\mathrm{CH}_{3}\right) ; \mathrm{IR}\left(\mathrm{cm}^{-1}\right): 1620,1600$, 1543, 1475, 1365, 1317, 1284, 1211; MS (ESI) $\mathrm{m} / z$ (\%): $263.0(100)[\mathrm{M}+\mathrm{H}]^{+}$; UPLC purity = $100 \%, t_{\mathrm{R}} 2.68 \mathrm{~min}$. Literature spectroscopic data [59].

\section{1-(4-Iodo-2-methoxyphenyl)ethanone (23)}

1-(2-Hydroxy-4-iodophenyl)ethanone $22(1.00 \mathrm{~g}, 3.8 \mathrm{mmol})$ and cesium carbonate $(3.71 \mathrm{~g}, 11.4 \mathrm{mmol})$ were introduced in a round-bottom flask under argon. Dry acetonitrile ( $30 \mathrm{~mL}$ ) was added, followed by iodomethane $(490 \mu \mathrm{L}, 7.6 \mathrm{mmol})$. The reaction mixture was stirred at $70{ }^{\circ} \mathrm{C}$ for $2 \mathrm{~h}$ and then the reaction was diluted with water $(50 \mathrm{~mL})$ and extracted with dichloromethane $(2 \times 50 \mathrm{~mL})$. The combined organic extracts were dried over sodium sulfate and filtered. The solvent was evaporated in vacuo and the residue was purified by silica gel column chromatography using cyclohexane/ethyl acetate $(8 / 2)$ to give compound 23 as a white powder $\left(0.95 \mathrm{~g}, 91 \%\right.$ yield). $R_{\mathrm{f}} 0.53$ (cyHex/AcOEt 8:2); Mp: 70-71 ${ }^{\circ} \mathrm{C}$ (lit. 69-70 $\left.{ }^{\circ} \mathrm{C}[60]\right) ;{ }^{1} \mathrm{H}$ NMR $\left(400 \mathrm{MHz}\right.$, DMSO- $\left.d_{6}\right) \delta 7.53\left(\mathrm{~d}, J=1.4 \mathrm{~Hz}, 1 \mathrm{H}, \mathrm{H}_{3}\right)$, $7.42\left(\mathrm{dd}, J=8.1,1.5 \mathrm{~Hz}, 1 \mathrm{H}, \mathrm{H}_{5}\right), 7.32\left(\mathrm{~d}, J=8.1 \mathrm{~Hz}, 1 \mathrm{H}, \mathrm{H}_{6}\right), 3.91(\mathrm{~s}, 3 \mathrm{H}), 3.33\left(\mathrm{~s}, 3 \mathrm{H}, \mathrm{CH}_{3}\right)$; ${ }^{13} \mathrm{C}$ NMR (100 MHz, DMSO- $\left.d_{6}\right) \delta 198.1(\mathrm{C}=\mathrm{O}), 158.5\left(\mathrm{C}_{2}\right), 130.8\left(\mathrm{C}_{5}\right), 129.4\left(\mathrm{C}_{6}\right), 127.3\left(\mathrm{C}_{1}\right)$, $121.4\left(\mathrm{C}_{3}\right), 101.0\left(\mathrm{C}_{4}\right), 56.2\left(\mathrm{CH}_{3}\right), 31.4\left(\mathrm{CH}_{3}\right)$; MS (ESI) $\mathrm{m} / z(\%): 277.0(100)[\mathrm{M}+\mathrm{H}]^{+}$; UPLC purity $=97 \%, t_{\mathrm{R}} 2.62 \mathrm{~min}$.

\section{1-Iodo-3-methoxybenzene (24)}

3-Iodophenol 20 (1.00 g, $4.5 \mathrm{mmol})$ and cesium carbonate $(2.40 \mathrm{~g}, 6.8 \mathrm{mmol})$ were introduced in a round-bottom flask under argon. Dry acetonitrile $(30 \mathrm{~mL})$ was added, followed by iodomethane $(420 \mu \mathrm{L}, 6.8 \mathrm{mmol})$. The reaction mixture was stirred at 70 ${ }^{\circ} \mathrm{C}$ for $4 \mathrm{~h}$ and then the reaction was diluted with water $(50 \mathrm{~mL})$ and extracted with dichloromethane $(3 \times 50 \mathrm{~mL})$. The combined organic extracts were dried over sodium sulfate and filtered. The solvent was evaporated in vacuo and the residue was purified by silica gel column chromatography using cyclohexane/ethyl acetate $(9 / 1)$ as the eluent to give compound 24 (940 mg, 89\% yield) as a yellow oil. $R_{\mathrm{f}} 0.57$ (cyHex/AcOEt 8:2); ${ }^{1} \mathrm{H}$ 
$\operatorname{NMR}\left(400 \mathrm{MHz}, \mathrm{CDCl}_{3}\right) \delta 7.24-7.14\left(\mathrm{~m}, 2 \mathrm{H}, \mathrm{H}_{2,6}\right), 6.91\left(\mathrm{t}, J=8.0 \mathrm{~Hz}, 1 \mathrm{H}, \mathrm{H}_{5}\right), 6.78(\mathrm{ddd}, J=$ 8.4, 2.5, $\left.0.9 \mathrm{~Hz}, 1 \mathrm{H}, \mathrm{H}_{4}\right), 3.69\left(\mathrm{~s}, 3 \mathrm{H}, \mathrm{OCH}_{3}\right) ;{ }^{13} \mathrm{C} \mathrm{NMR}\left(100 \mathrm{MHz}, \mathrm{CDCl}_{3}\right) \delta 160.1\left(\mathrm{C}_{3}\right), 130.7$ $\left(\mathrm{C}_{6}\right), 129.8\left(\mathrm{C}_{5}\right), 123.0\left(\mathrm{C}_{2}\right), 113.7\left(\mathrm{C}_{4}\right), 94.3\left(\mathrm{C}_{1}\right), 55.3\left(\mathrm{CH}_{3}\right)$; MS (ESI) $\mathrm{m} / z(\%): 235.1(100)$ $[\mathrm{M}+\mathrm{H}]^{+}$; UPLC purity $=97 \%, t_{\mathrm{R}} 2.87 \mathrm{~min}$. Literature spectroscopic data [61].

\subsubsection{General Procedure for the Preparation of Diaryl Ethers 28-32}

To a solution of 3,5-dimethoxyphenol 4 (1 equiv.) in N,N-dimethylformamide, cesium carbonate (2 equiv.), copper(1) iodide (0.1 equiv.), and iodo-aryl derivatives $23-27$ (1.5 equiv.) were added. The reaction mixture was irradiated using microwave heating at $110{ }^{\circ} \mathrm{C}$ for $1 \mathrm{~h}$. After cooling to room temperature, the mixture was diluted with ethyl acetate $(50 \mathrm{~mL})$ and water $(100 \mathrm{~mL})$. The suspension was filtered through a pad of Celite ${ }^{\circledR}$. The two layers were separated, and the organic layer was washed with water $(3 \times 50 \mathrm{~mL})$, dried over sodium sulfate, filtered, and evaporated to dryness. The crude product was then purified by chromatography to provide 28-32.

\section{1-[4-(3',5'-Dimethoxyphenoxy)-2-methoxyphenyl] ethanone (28)}

The reaction was carried out using 3,5-dimethoxyphenol 4 (400 mg, $2.6 \mathrm{mmol}), \mathrm{Cs}_{2} \mathrm{CO}_{3}$ (1.69 g, $5.2 \mathrm{mmol}), \mathrm{CuI}(50 \mathrm{mg}, 0.26 \mathrm{mmol})$, and 1-(4-iodo-2-methoxyphenyl)ethanone 23 $(1.08 \mathrm{~g}, 3.9 \mathrm{mmol})$ in DMF (3 mL). Purification by flash column chromatography using cyclohexane/ethyl acetate (8/2) as the eluent afforded compound $\mathbf{2 8}(266 \mathrm{mg}, 34 \%$ yield) as a colorless oil. $R_{\mathrm{f}} 0.54$ (cyHex/AcOEt 8:2); ${ }^{1} \mathrm{H}$ NMR $\left(400 \mathrm{MHz}, \mathrm{CDCl}_{3}\right) \delta 7.78(\mathrm{~d}, J=8.8 \mathrm{~Hz}$, $\left.1 \mathrm{H}, \mathrm{H}_{6}\right), 6.61\left(\mathrm{~d}, J=2.2 \mathrm{~Hz}, 1 \mathrm{H}, \mathrm{H}_{3}\right), 6.56\left(\mathrm{dd}, J=8.7,1.4 \mathrm{~Hz}, 1 \mathrm{H}, \mathrm{H}_{5}\right), 6.29(\mathrm{t}, J=2.2 \mathrm{~Hz}, 1 \mathrm{H}$, $\left.\mathrm{H}_{4^{\prime}}\right), 6.22-6.21\left(\mathrm{~m}, 2 \mathrm{H}, \mathrm{H}_{2^{\prime}}, 6^{\prime}\right), 3.86\left(\mathrm{~s}, 3 \mathrm{H}, \mathrm{CH}_{3}\right), 3.76\left(\mathrm{~s}, 6 \mathrm{H}, 2 \mathrm{CH}_{3}\right), 2.59\left(\mathrm{~s}, 3 \mathrm{H}, \mathrm{COCH}_{3}\right)$; ${ }^{13} \mathrm{C}$ NMR (100 MHz, $\left.\mathrm{CDCl}_{3}\right) \delta 198.2(\mathrm{C}=\mathrm{O}), 162.3\left(\mathrm{C}_{2}\right), 161.9\left(2 \mathrm{C}_{3^{\prime}, 5^{\prime}}\right), 161.0\left(\mathrm{C}_{4}\right), 157.5$ $\left(\mathrm{C}_{1^{\prime}}\right), 132.6\left(\mathrm{C}_{6}\right), 123.0\left(\mathrm{C}_{1}\right), 109.9\left(\mathrm{C}_{5}\right), 101.9\left(\mathrm{C}_{3}\right), 98.5\left(2 \mathrm{C}_{2^{\prime}, 6^{\prime}}\right), 96.9\left(\mathrm{C}_{4^{\prime}}\right), 55.8\left(\mathrm{OCH}_{3}\right), 55.6$ $\left(2 \mathrm{OCH}_{3}\right), 31.9\left(\mathrm{COCH}_{3}\right)$; IR $\left(\mathrm{cm}^{-1}\right): 2839,1644,1579,1462,1419,1357,1257,1195,1149$, 1128, 1051, 1028; MS (ESI) $m / z(\%): 303.2(100)[\mathrm{M}+\mathrm{H}]^{+}$; UPLC purity $=98 \%, t_{\mathrm{R}} 2.98 \mathrm{~min}$.

\section{1,3-Dimethoxy-5-(3'-methoxyphenoxy)benzene (29)}

The reaction was carried out using 3,5-dimethoxyphenol 4 (200 mg, $1.30 \mathrm{mmol}$ ), $\mathrm{Cs}_{2} \mathrm{CO}_{3}$ (847 mg, $\left.2.60 \mathrm{mmol}\right), \mathrm{CuI}(25 \mathrm{mg}, 0.13 \mathrm{mmol})$, and 1-iodo-3-methoxybenzene 24 (455 mg, $1.95 \mathrm{mmol})$ in DMF (3 mL). Purification by flash column chromatography using cyclohexane/ethyl acetate (9/1) as the eluent afforded compound 29 (103 $\mathrm{mg}, 30 \%$ yield) as a colorless oil. $R_{\mathrm{f}} 0.55$ (cyHex/AcOEt 8:2); ${ }^{1} \mathrm{H}$ NMR $\left(400 \mathrm{MHz}, \mathrm{CDCl}_{3}\right) \delta 7.15(\mathrm{t}, J=8.1$ $\left.\mathrm{Hz}, 1 \mathrm{H}, \mathrm{H}_{5^{\prime}}\right), 6.64-6.49\left(\mathrm{~m}, 3 \mathrm{H}, \mathrm{H}_{2^{\prime}}, 4^{\prime}, 6^{\prime}\right), 6.15\left(\mathrm{t}, J=2.2 \mathrm{~Hz}, 1 \mathrm{H}, \mathrm{H}_{2}\right), 6.11(\mathrm{~d}, J=2.4 \mathrm{~Hz}, 1 \mathrm{H})$, $6.11(\mathrm{~d}, J=2.4 \mathrm{~Hz}, 1 \mathrm{H}), 3.71\left(\mathrm{~s}, 3 \mathrm{H}, \mathrm{CH}_{3}\right), 3.67\left(\mathrm{~s}, 6 \mathrm{H}, 2 \mathrm{CH}_{3}\right) . ;{ }^{13} \mathrm{C} \mathrm{NMR}\left(100 \mathrm{MHz} \mathrm{CDCl}_{3}\right)$ $\delta 161.5\left(2 \mathrm{C}_{1,3}\right), 160.9\left(\mathrm{C}_{3^{\prime}}\right), 158.9\left(\mathrm{C}_{1^{\prime}}\right), 157.9\left(\mathrm{C}_{5}\right), 130.0\left(\mathrm{C}_{5}\right), 111.3\left(\mathrm{C}_{6^{\prime}}\right), 109.1\left(\mathrm{C}_{2^{\prime}}\right), 105.1$ $\left(\mathrm{C}_{4^{\prime}}\right), 97.4\left(2 \mathrm{C}_{4,6}\right), 95.6\left(\mathrm{C}_{2}\right), 55.4\left(2 \mathrm{CH}_{3}\right), 55.3\left(\mathrm{CH}_{3}\right)$; IR $\left(\mathrm{cm}^{-1}\right): 2835,1583,1261,1193,1143$, 1126, 1047; MS (ESI) $m / z(\%): 261.1(100)[\mathrm{M}+\mathrm{H}]^{+}$; UPLC purity $=99 \%, t_{\mathrm{R}} 3.20 \mathrm{~min}$.

1-[4-(3',5'-Dimethoxyphenoxy)phenyl]ethanone (30)

The reaction was carried out using 3,5-dimethoxyphenol 4 (1.00 g, $6.5 \mathrm{mmol}), \mathrm{Cs}_{2} \mathrm{CO}_{3}$ (4.23g, $13 \mathrm{mmol}), \mathrm{CuI}(124 \mathrm{mg}, 0.65 \mathrm{mmol})$, and 4-iodoacetophenone 25 (2.40 g, $9.7 \mathrm{mmol})$ in DMF ( $5 \mathrm{~mL})$. Purification by flash column chromatography using cyclohexane/ethyl acetate $(8 / 2)$ as the eluent afforded compound $30(1.20 \mathrm{~g}, 71 \%$ yield $)$ as a brown powder. $R_{\mathrm{f}}$ 0.60 (cyHex/AcOEt 8:2); Mp: 85-86 ${ }^{\circ} \mathrm{C} ;{ }^{1} \mathrm{H}$ NMR (400 MHz, CDCl 3 ) 87.96 (mt, 2H, H2,6), $7.05\left(\mathrm{mt}, 2 \mathrm{H}, \mathrm{H}_{3,5}\right), 6.32\left(\mathrm{t}, J=2.2 \mathrm{~Hz}, 1 \mathrm{H}, \mathrm{H}_{4^{\prime}}\right), 6.24\left(\mathrm{~d}, J=2.3 \mathrm{~Hz}, 2 \mathrm{H}_{,} \mathrm{H}_{2^{\prime}, 6^{\prime}}\right), 3.79(\mathrm{~s}, 6 \mathrm{H}$, $\left.2 \mathrm{CH}_{3}\right), 2.60\left(\mathrm{~s}, 3 \mathrm{H}, \mathrm{COCH}_{3}\right) ;{ }^{13} \mathrm{C} \mathrm{NMR}\left(100 \mathrm{MHz}, \mathrm{CDCl}_{3}\right) \delta 196.7(\mathrm{C}=\mathrm{O}), 161.7\left(2 \mathrm{C}_{3^{\prime}, 5^{\prime}}\right)$, $161.5\left(C_{4}\right), 157.3\left(C_{1^{\prime}}\right), 132.1\left(C_{1}\right), 130.5\left(2 C_{2,6}\right), 117.6\left(2 C_{3,5}\right), 98.5\left(2 C_{2^{\prime}, 6^{\prime}}\right), 96.7\left(C_{4^{\prime}}\right), 55.4$ $\left(2 \mathrm{CH}_{3}\right), 26.4\left(\mathrm{COCH}_{3}\right)$; IR $\left(\mathrm{cm}^{-1}\right): 1674,1585,1425,1361,1267,1230,1136,1053$; MS (ESI) $m / z(\%): 273.2(100)[\mathrm{M}+\mathrm{H}]^{+}$; UPLC purity $=99 \%, t_{\mathrm{R}} 2.92 \mathrm{~min}$. 
1-(4'-Fluorophenoxy)-3,5-dimethoxybenzene (31)

The reaction was carried out using 3,5-dimethoxyphenol $4(1.00 \mathrm{~g}, 6.5 \mathrm{mmol}), \mathrm{Cs}_{2} \mathrm{CO}_{3}$ (4.23 g, $13 \mathrm{mmol})$, CuI (124 mg, $0.65 \mathrm{mmol})$, and 1-fluoro-4-iodobenzene 26 (1.1 mL, $9.75 \mathrm{mmol})$ in DMF ( $5 \mathrm{~mL})$. Purification by flash column chromatography using cyclohexane/ethyl acetate $(8 / 2)$ as the eluent afforded compound $31\left(1.23 \mathrm{~g}, 76 \%\right.$ yield) as a yellow oil. $R_{\mathrm{f}} 0.30$ (cyHex $\left./ \mathrm{CH}_{2} \mathrm{Cl}_{2} 8: 2\right) ;{ }^{1} \mathrm{H}$ NMR (400 MHz, DMSO- $\left.d_{6}\right) \delta 7.22\left(\mathrm{t}, J=8.4 \mathrm{~Hz}, 2 \mathrm{H}, \mathrm{H}_{3^{\prime}, 5^{\prime}}\right), 7.08(\mathrm{dd}$, $\left.J=8.4,4.6 \mathrm{~Hz} 2 \mathrm{H}, \mathrm{H}_{2^{\prime}, 6^{\prime}}\right), 6.28\left(\mathrm{t}, J=2.4 \mathrm{~Hz}, 1 \mathrm{H}, \mathrm{H}_{4}\right), 6.11\left(\mathrm{~d}, J=2.4 \mathrm{~Hz}, 2 \mathrm{H}, \mathrm{H}_{2,6}\right), 3.70(\mathrm{~s}, 6 \mathrm{H}$, $\left.2 \mathrm{CH}_{3}\right) ;{ }^{13} \mathrm{C}$ NMR $\left(100 \mathrm{MHz}\right.$, DMSO- $\left.d_{6}\right) \delta 161.3\left(2 \mathrm{C}_{3,5}\right), 158.9\left(\mathrm{C}_{1}\right), 158.3\left(\mathrm{~d}, J_{\mathrm{CF}}=238 \mathrm{~Hz}, \mathrm{C}_{4^{\prime}}\right)$, $152.1\left(\mathrm{~d}, J_{C F}=2 \mathrm{~Hz}, \mathrm{C}_{1^{\prime}}\right), 120.8\left(\mathrm{~d}, J_{C F}=8 \mathrm{~Hz}, 2 \mathrm{C}_{2^{\prime}, 6^{\prime}}\right), 116.4\left(\mathrm{~d}, J_{\mathrm{CF}}=24 \mathrm{~Hz}, 2 \mathrm{C}_{3^{\prime}, 5^{\prime}}\right), 96.6\left(2 \mathrm{C}_{2,6}\right)$, $95.3\left(\mathrm{C}_{4}\right), 55.2\left(2 \mathrm{CH}_{3}\right)$; IR $\left(\mathrm{cm}^{-1}\right)$ : 2943, 2839, 1591, 1499, 1462, 1238, 1150, 824; MS (ESI) $\mathrm{m} / z(\%)$ : $249.1(100)[\mathrm{M}+\mathrm{H}]^{+}$; UPLC purity $=100 \%, t_{\mathrm{R}} 3.55 \mathrm{~min}$.

\section{1,3-Dimethoxy-5-[4'-(trifluoromethyl)phenoxy]benzene (32)}

The reaction was carried out using 3,5-dimethoxyphenol $4(500 \mathrm{mg}, 3.25 \mathrm{mmol}$ ), $\mathrm{Cs}_{2} \mathrm{CO}_{3}(2.12 \mathrm{~g}, 6.5 \mathrm{mmol}), \mathrm{CuI}(62 \mathrm{mg}, 325 \mu \mathrm{mol})$, and 1-iodo-4-(trifluoromethyl)benzene $27(720 \mu \mathrm{L}, 4.87 \mathrm{mmol})$ in DMF ( $3 \mathrm{~mL})$. Purification by flash column chromatography using cyclohexane/ethyl acetate (8/2) as the eluent afforded compound $32(678 \mathrm{mg}, 70 \%$ yield) as a colorless oil. $R_{\mathrm{f}} 0.29$ (cyHex $\left./ \mathrm{CH}_{2} \mathrm{Cl}_{2} 8: 2\right) ;{ }^{1} \mathrm{H} \mathrm{NMR}\left(400 \mathrm{MHz}, \mathrm{CDCl}_{3}\right) \delta 7.58(\mathrm{~d}, J=8.5 \mathrm{~Hz}$, $\left.2 \mathrm{H}, \mathrm{H}_{3^{\prime}, 5^{\prime}}\right), 7.08\left(\mathrm{~d}, J=8.5 \mathrm{~Hz}, 2 \mathrm{H}, \mathrm{H}_{2^{\prime}, 6^{\prime}}\right), 6.30\left(\mathrm{t}, J=2.2 \mathrm{~Hz}, 1 \mathrm{H}, \mathrm{H}_{2}\right), 6.21(\mathrm{~d}, J=2.2 \mathrm{~Hz}$, $\left.2 \mathrm{H}, \mathrm{H}_{4,6}\right), 3.77\left(\mathrm{~s}, 6 \mathrm{H}, 2 \mathrm{CH}_{3}\right) ;{ }^{13} \mathrm{C} \mathrm{NMR}\left(100 \mathrm{MHz}, \mathrm{CDCl}_{3}\right) \delta 161.9\left(2 \mathrm{C}_{1,3}\right), 160.1\left(\mathrm{C}_{5}\right), 157.6$ $\left(\mathrm{C}_{1^{\prime}}\right), 127.1\left(\mathrm{q}, J_{C F}=4 \mathrm{~Hz}, 2 \mathrm{C}_{3^{\prime}, 5^{\prime}}\right), 125.2\left(\mathrm{q}, J_{C F}=310 \mathrm{~Hz}, \mathrm{CF}_{3}\right), 122.8\left(\mathrm{C}_{4^{\prime}}\right), 118.2\left(2 \mathrm{C}_{2^{\prime}, 6^{\prime}}\right)$, $98.3\left(2 \mathrm{C}_{4,6}\right), 96.6\left(\mathrm{C}_{2}\right), 55.5\left(2 \mathrm{CH}_{3}\right)$; IR $\left(\mathrm{cm}^{-1}\right): 2943,1589,1321,1105,835$; MS (ESI) $\mathrm{m} / z(\%)$ : $299.1(100)[\mathrm{M}+\mathrm{H}]^{+}$; UPLC purity $=99 \%, t_{\mathrm{R}} 3.42 \mathrm{~min}$.

\subsubsection{General Procedure for the Preparation of 1,3-dimethoxydibenzofurans 33-37}

Diaryl ethers 28-32 (1 equiv.) were dissolved in warm pivalic acid $\left(50{ }^{\circ} \mathrm{C}\right.$, excess). Silver acetate (5 equiv.) and palladium (II) acetate ( 0.1 equiv.) were added, and the reaction mixture was properly stirred at $130{ }^{\circ} \mathrm{C}$ for $4-24 \mathrm{~h}$. After cooling to room temperature, the mixture was diluted with methanol $(50 \mathrm{~mL})$ and $\mathrm{NaOH}(1 \mathrm{M})$ was added until the $\mathrm{pH}$ reached 9. Elemental silver was removed by filtration through a pad of Celite ${ }^{\circledR}$. The filtrate was extracted with ethyl acetate $(100 \mathrm{~mL})$. The organic layers were washed with brine $(2 \times 100 \mathrm{~mL})$, dried over sodium sulfate, filtered, and evaporated to dryness. The crude product was then purified by chromatography to provide 33-37.

\section{1-(3,7,9-Trimethoxydibenzo[b,d]furan-2-yl)ethanone (33)}

The reaction was carried out using 1-[4-(3,5-dimethoxyphenoxy)-2-methoxyphenyl] ethanone 28 (100 mg, $0.33 \mathrm{mmol})$ and $\mathrm{AgOAc}(275 \mathrm{mg}, 1.65 \mathrm{mmol}), \mathrm{Pd}(\mathrm{OAc})_{2}(9 \mathrm{mg}$, $0.03 \mathrm{mmol}$ ) in PivOH (5 g) for $4 \mathrm{~h}$. Purification by flash column chromatography using cyclohexane/ethyl acetate (8/2) as the eluent afforded compound $33(86 \mathrm{mg}, 87 \%$ yield) as a brown powder. $R_{\mathrm{f}} 0.48$ (cyHex/AcOEt 8:2); Mp: $155-156{ }^{\circ} \mathrm{C} ;{ }^{1} \mathrm{H}$ NMR $(400 \mathrm{MHz}$, DMSO- $\left.d_{6}\right) \delta 8.10\left(\mathrm{~s}, 1 \mathrm{H}, \mathrm{H}_{1}\right), 7.46\left(\mathrm{~s}, 1 \mathrm{H}, \mathrm{H}_{4}\right), 6.92\left(\mathrm{~d}, J=1.9 \mathrm{~Hz}, 1 \mathrm{H}, \mathrm{H}_{6}\right), 6.57(\mathrm{~d}, J=1.9 \mathrm{~Hz}$, $\left.1 \mathrm{H}, \mathrm{H}_{8}\right), 3.99\left(\mathrm{~s}, 3 \mathrm{H}, \mathrm{CH}_{3}\right), 3.98\left(\mathrm{~s}, 3 \mathrm{H}, \mathrm{CH}_{3}\right), 3.86\left(\mathrm{~s}, 3 \mathrm{H}, \mathrm{CH}_{3}\right), 2.58\left(\mathrm{~s}, 3 \mathrm{H}, \mathrm{COCH}_{3}\right) ;{ }^{13} \mathrm{C}$ NMR (100 MHz, DMSO- $\left.d_{6}\right) \delta 198.0(\mathrm{C}=\mathrm{O}), 160.6\left(\mathrm{C}_{7}\right), 158.5\left(\mathrm{C}_{3}\right), 158.0(\mathrm{C}), 157.9(\mathrm{C}), 154.9$ $\left(\mathrm{C}_{9}\right), 124.1\left(\mathrm{C}_{2}\right), 121.9\left(\mathrm{C}_{1}\right), 115.9(\mathrm{C}), 105.4(\mathrm{C}), 95.8\left(\mathrm{C}_{8}\right), 94.5\left(\mathrm{C}_{6}\right), 89.2\left(\mathrm{C}_{4}\right), 56.3\left(\mathrm{CH}_{3}\right)$, $55.9\left(\mathrm{CH}_{3}\right), 55.8\left(\mathrm{CH}_{3}\right), 31.6\left(\mathrm{CH}_{3}\right)$; IR $\left(\mathrm{cm}^{-1}\right): 1664,1600,1462,1408,1354,1269,1236,1139$, 1095; MS (ESI) $m / z(\%): 301.2(100)[\mathrm{M}+\mathrm{H}]^{+}$; UPLC purity $=99 \%, t_{\mathrm{R}} 3.00 \mathrm{~min}$.

\section{1,3,7-Trimethoxydibenzo[ $b, d]$ furan (34)}

The reaction was carried out using 1,3-dimethoxy-5-(3-methoxyphenoxy)benzene 29 (100 mg, $0.38 \mathrm{mmol})$, AgOAc ( $317 \mathrm{mg}, 1.90 \mathrm{mmol})$, and $\mathrm{Pd}(\mathrm{OAc})_{2}(9 \mathrm{mg}, 0.04 \mathrm{mmol})$ in PivOH ( $5 \mathrm{~g}$ ) for $12 \mathrm{~h}$. Purification by flash column chromatography using cyclohexane/ethyl acetate (8/2) as the eluent afforded compound $34(90 \mathrm{mg}, 91 \%$ yield) as a brown powder. $R_{\mathrm{f}} 0.51$ (cyHex/AcOEt 8:2); Mp: $153-154{ }^{\circ} \mathrm{C} ;{ }^{1} \mathrm{H}$ NMR $\left(400 \mathrm{MHz}, \mathrm{CDCl}_{3}\right) \delta 7.78$ $\left(\mathrm{d}, J=8.4 \mathrm{~Hz}, 1 \mathrm{H}, \mathrm{H}_{9}\right), 6.97\left(\mathrm{~d}, J=2.2 \mathrm{~Hz}, 1 \mathrm{H}, \mathrm{H}_{6}\right), 6.82\left(\mathrm{dd}, J=8.4,2.3 \mathrm{~Hz}, 1 \mathrm{H}, \mathrm{H}_{8}\right), 6.61$ 
$\left(\mathrm{d}, J=1.9 \mathrm{~Hz}, 1 \mathrm{H}, \mathrm{H}_{4}\right), 6.32\left(\mathrm{~d}, J=2.0 \mathrm{~Hz}, 1 \mathrm{H}, \mathrm{H}_{2}\right), 3.91\left(\mathrm{~s}, 3 \mathrm{H}, \mathrm{CH}_{3}\right), 3.80\left(\mathrm{~s}, 3 \mathrm{H}, \mathrm{CH}_{3}\right), 3.80$ $\left(\mathrm{s}, 3 \mathrm{H}, \mathrm{CH}_{3}\right) ;{ }^{13} \mathrm{C} \mathrm{NMR}\left(100 \mathrm{MHz}, \mathrm{CDCl}_{3}\right) \delta 160.0\left(\mathrm{C}_{3}\right), 158.2\left(\mathrm{C}_{7}\right), 158.1(\mathrm{C}), 156.6(\mathrm{C}), 155.2$ $\left(\mathrm{C}_{1}\right), 121.8\left(\mathrm{C}_{9}\right), 117.0(\mathrm{C}), 110.4\left(\mathrm{C}_{8}\right), 107.2(\mathrm{C}), 96.4\left(\mathrm{C}_{2}\right), 93.8\left(\mathrm{C}_{4}\right), 88.7\left(\mathrm{C}_{6}\right), 55.8\left(\mathrm{CH}_{3}\right)$, $55.7\left(\mathrm{CH}_{3}\right), 55.6\left(\mathrm{CH}_{3}\right)$; IR $\left(\mathrm{cm}^{-1}\right)$ : 2940, 2832, 1594, 1435, 1365, 1320, 1264, 1206, 1125, 1036; MS (ESI) $m / z(\%): 259.1(100)[\mathrm{M}+\mathrm{H}]^{+}$; UPLC purity $=99 \%, t_{\mathrm{R}} 3.24 \mathrm{~min}$.

1-(7,9-Dimethoxydibenzo[ $b, d]$ furan-2-yl)ethanone (35)

The reaction was carried out using 1-[4-(3,5-dimethoxyphenoxy)phenyl]ethanone 30 (1.00 g, $3.7 \mathrm{mmol}), \mathrm{AgOAc}(3.06 \mathrm{~g}, 18.5 \mathrm{mmol})$, and Pd(OAc) 2 (80 mg, $0.37 \mathrm{mmol})$ in PivOH (50 g) for $24 \mathrm{~h}$. Purification by flash column chromatography using cyclohexane/ethyl acetate $(8 / 2)$ as the eluent afforded compound $35(0.83 \mathrm{~g}, 83 \%$ yield $)$ as a brown powder. $R_{\mathrm{f}} 0.34$ (cyHex/AcOEt 8:2); Mp: $162-163{ }^{\circ} \mathrm{C} ;{ }^{1} \mathrm{H}$ NMR (400 MHz, $\left.\mathrm{CDCl}_{3}\right) \delta 8.60\left(\mathrm{~d}, J=1.9 \mathrm{~Hz}, 1 \mathrm{H}, \mathrm{H}_{1}\right)$, $8.02\left(\mathrm{dd}, J=8.6,2.0 \mathrm{~Hz}, 1 \mathrm{H}, \mathrm{H}_{3}\right), 7.52\left(\mathrm{~d}, J=8.6 \mathrm{~Hz}, 1 \mathrm{H}, \mathrm{H}_{4}\right), 6.74\left(\mathrm{~d}, J=1.9 \mathrm{~Hz}, 1 \mathrm{H}, \mathrm{H}_{6}\right), 6.46$ $\left(\mathrm{d}, \mathrm{J}=1.9 \mathrm{~Hz}, 1 \mathrm{H}, \mathrm{H}_{8}\right), 4.06\left(\mathrm{~s}, 3 \mathrm{H}, \mathrm{CH}_{3}\right), 3.92\left(\mathrm{~s}, 3 \mathrm{H}, \mathrm{CH}_{3}\right), 2.73\left(\mathrm{~s}, 3 \mathrm{H}, \mathrm{COCH}_{3}\right) ;{ }^{13} \mathrm{C} \mathrm{NMR}$ $\left(100 \mathrm{MHz}, \mathrm{CDCl}_{3}\right) \delta 197.6(\mathrm{C}=\mathrm{O}), 161.6\left(\mathrm{C}_{7}\right), 158.8(\mathrm{C}), 158.3\left(\mathrm{C}_{9}\right), 156.1(\mathrm{C}), 132.7\left(\mathrm{C}_{2}\right), 125.8$ $\left(\mathrm{C}_{3}\right), 124.1(\mathrm{C}), 122.6\left(\mathrm{C}_{1}\right), 110.6\left(\mathrm{C}_{4}\right), 106.7(\mathrm{C}), 94.4\left(\mathrm{C}_{8}\right), 88.6\left(\mathrm{C}_{6}\right), 55.8\left(\mathrm{CH}_{3}\right), 55.7\left(\mathrm{CH}_{3}\right), 26.8$ $\left(\mathrm{COCH}_{3}\right)$; IR (cm $\left.{ }^{-1}\right): 1674,1637,1618,1581,1510,1425,1408,1361,1315,1290,1253,1215,1197$, 1151, 1093, 1045, 1010; MS (ESI) $m / z(\%): 271.2(100)[\mathrm{M}+\mathrm{H}]^{+}$; UPLC purity $=98 \%, t_{\mathrm{R}} 2.94 \mathrm{~min}$.

8-Fluoro-1,3-dimethoxydibenzo[b,d]furan (36)

The reaction was carried out using 1-(4-fluorophenoxy)-3,5-dimethoxybenzene 31 (1.00 g, $4.03 \mathrm{mmol}), \mathrm{AgOAc}(3.36 \mathrm{~g}, 20.15 \mathrm{mmol})$, and $\mathrm{Pd}(\mathrm{OAc})_{2}(90 \mathrm{mg}, 0.40 \mathrm{mmol})$ in PivOH (50 g) for $24 \mathrm{~h}$. Purification by flash column chromatography using cyclohexane/dichloromethane (8/2) as the eluent afforded compound 36 (414 $\mathrm{mg}, 42 \%$ yield) as a white powder. $R_{\mathrm{f}} 0.23$ (cyHex $/ \mathrm{CH}_{2} \mathrm{Cl}_{2} 8: 2$ ); $\mathrm{Mp}: 137-138{ }^{\circ} \mathrm{C} ;{ }^{1} \mathrm{H} \mathrm{NMR}\left(400 \mathrm{MHz}, \mathrm{CDCl}_{3}\right) \delta$ $7.66\left(\mathrm{dd}, J=8.5,2.7 \mathrm{~Hz}, 1 \mathrm{H}, \mathrm{H}_{9}\right), 7.39\left(\mathrm{dd}, J=8.9,4.1 \mathrm{~Hz}, 1 \mathrm{H}, \mathrm{H}_{6}\right), 7.02(\mathrm{dt}, J=8.9,2.7 \mathrm{~Hz}$, $\left.1 \mathrm{H}, \mathrm{H}_{7}\right), 6.68\left(\mathrm{~d}, J=2.0 \mathrm{~Hz}, 1 \mathrm{H}, \mathrm{H}_{2}\right), 6.39\left(\mathrm{~d}, J=2.0 \mathrm{~Hz}, 1 \mathrm{H}, \mathrm{H}_{4}\right), 4.00\left(\mathrm{~s}, 3 \mathrm{H}, \mathrm{CH}_{3}\right), 3.89$ $\left(\mathrm{s}, 3 \mathrm{H}, \mathrm{CH}_{3}\right) ;{ }^{13} \mathrm{C} \mathrm{NMR}\left(100 \mathrm{MHz}, \mathrm{CDCl}_{3}\right) \delta 161.6\left(\mathrm{C}_{3}\right), 159.2\left(\mathrm{C}_{4 \mathrm{a}}\right), 159.1\left(\mathrm{~d}, J_{\mathrm{CF}}=238 \mathrm{~Hz}\right.$, $\left.\mathrm{C}_{8}\right), 156.0\left(\mathrm{C}_{1}\right), 151.5\left(\mathrm{C}_{9 \mathrm{~b}}\right), 124.7\left(\mathrm{~d}, J_{C F}=11 \mathrm{~Hz}, \mathrm{C}_{9 \mathrm{a}}\right), 111.7\left(\mathrm{~d}, J_{C F}=26 \mathrm{~Hz}, \mathrm{C}_{7}\right), 111.0$ $\left(\mathrm{d}, J_{C F}=9 \mathrm{~Hz}, \mathrm{C}_{6}\right), 107.9\left(\mathrm{~d}, J_{C F}=25 \mathrm{~Hz}, \mathrm{C}_{9}\right), 107.2\left(\mathrm{~d}, J_{C F}=3 \mathrm{~Hz}, \mathrm{C}_{5 \mathrm{a}}\right), 93.9\left(\mathrm{C}_{4}\right), 88.5\left(\mathrm{C}_{2}\right)$, $55.8\left(\mathrm{CH}_{3}\right), 55.7\left(\mathrm{CH}_{3}\right)$; IR $\left(\mathrm{cm}^{-1}\right)$ : 1674, 1637, 1618, 1581, 1510, 1425, 1408, 1361, 1315, 1290, 1253, 1215, 1197, 1151, 1093, 1045, 1010; MS (ESI) $m / z(\%): 247.1(100)[\mathrm{M}+\mathrm{H}]^{+}$; UPLC purity $=99 \%, t_{\mathrm{R}} 3.23 \mathrm{~min}$.

\section{1,3-Dimethoxy-8-(trifluoromethyl)dibenzo[b,d]furan (37)}

The reaction was carried out using 1,3-dimethoxy-5-(4-(trifluoromethyl)phenoxy) benzene 32 (500 mg, $1.65 \mathrm{mmol})$, AgOAc (560 mg, $8.38 \mathrm{mmol})$, and Pd(OAc) 2 (37 mg, $0.165 \mathrm{mmol}$ ) in PivOH (25 g) for $24 \mathrm{~h}$. Purification by flash column chromatography using cyclohexane/dichloromethane (95/5) as the eluent afforded compound 37 (190 mg, $39 \%$ yield) as a white powder. $R_{\mathrm{f}} 0.21$ (cyHex $\left./ \mathrm{CH}_{2} \mathrm{Cl}_{2} 99: 1\right) ; \mathrm{Mp}: 131-132{ }^{\circ} \mathrm{C} ;{ }^{1} \mathrm{H} \mathrm{NMR}$ $\left(400 \mathrm{MHz} \mathrm{CDCl}_{3}\right) \delta 8.25\left(\mathrm{~s}, 1 \mathrm{H}, \mathrm{H}_{9}\right), 7.58\left(\mathrm{dd}, J=8.4,1.9 \mathrm{~Hz}, 1 \mathrm{H}, \mathrm{H}_{7}\right), 7.53(\mathrm{~d}, J=8.7 \mathrm{~Hz}$, $\left.1 \mathrm{H}, \mathrm{H}_{6}\right), 6.72\left(\mathrm{~d}, J=2.0 \mathrm{~Hz}, 1 \mathrm{H}, \mathrm{H}_{2}\right), 6.43\left(\mathrm{~d}, J=2.0 \mathrm{~Hz}, 1 \mathrm{H}, \mathrm{H}_{4}\right), 4.03\left(\mathrm{~s}, 3 \mathrm{H}, \mathrm{CH}_{3}\right), 3.90$ $\left(\mathrm{s}, 3 \mathrm{H}, \mathrm{CH}_{3}\right) ;{ }^{13} \mathrm{C} \mathrm{NMR}\left(100 \mathrm{MHz}, \mathrm{CDCl}_{3}\right) \delta 161.9\left(\mathrm{C}_{3}\right), 158.9\left(\mathrm{C}_{4 \mathrm{a}}\right), 157.0\left(\mathrm{C}_{9 \mathrm{~b}}\right), 156.1\left(\mathrm{C}_{1}\right)$, $126.1\left(\mathrm{C}_{8}\right), 125.3\left(\mathrm{q}, J_{C F}=310 \mathrm{~Hz}, \mathrm{CF}_{3}\right), 124.2\left(\mathrm{C}_{9 \mathrm{a}}\right), 121.9\left(\mathrm{q}, J_{C F}=4 \mathrm{~Hz}, \mathrm{C}_{7}\right), 119.2\left(\mathrm{q}, J_{C F}=4\right.$ $\left.\mathrm{Hz}, \mathrm{C}_{9}\right), 110.8\left(\mathrm{C}_{6}\right), 106.5\left(\mathrm{C}_{5 \mathrm{a}}\right), 94.4\left(\mathrm{C}_{4}\right), 88.6\left(\mathrm{C}_{2}\right), 55.9\left(\mathrm{CH}_{3}\right), 55.7\left(\mathrm{CH}_{3}\right) ; \mathrm{IR}\left(\mathrm{cm}^{-1}\right): 2947$, 1620, 1321, 1151, 1094, 808; MS (ESI) $m / z(\%): 297.1(100)[\mathrm{M}+\mathrm{H}]^{+}$; UPLC purity $=100 \%$, $t_{\mathrm{R}} 3.47 \mathrm{~min}$.

3.1.6. General Procedure for the Preparation of 1,3-dimethoxydibenzofuran-4carboxamides 38-42

To a stirred suspension of 1,3-dimethoxydibenzofurans 33-37 (1 equiv.) in acetonitrile at $0{ }^{\circ} \mathrm{C}$ under argon, chlorosulfonyl isocyanate ( 2 equiv.) was added. The mixture was maintained at room temperature for 6-12 $\mathrm{h}$ and then the reaction mixture was quenched with $\mathrm{HCl} 5 \mathrm{M}(20 \mathrm{~mL})$. After 6-12 h at room temperature, the reaction was diluted with water $(100 \mathrm{~mL})$ and extracted with ethyl acetate $(100 \mathrm{~mL})$. The combined organic extracts 
were washed with brine $(2 \times 100 \mathrm{~mL})$, dried over sodium sulfate, filtered, and evaporated to dryness. The crude product was then purified by chromatography to provide 38-42.

8-Acetyl-1,3,7-trimethoxydibenzo[ $b, d]$ furan-4-carboxamide (38)

Method A: The reaction was carried out using 1-(3,7,9-trimethoxydibenzo[ $b, d]$ furan-2yl)ethanone 33 (100 mg, $0.33 \mathrm{mmol})$, CSI (58 $\mu \mathrm{L}, 0.66 \mathrm{mmol})$ in $\mathrm{CH}_{3} \mathrm{CN}(10 \mathrm{~mL})$ for $12 \mathrm{~h}$ and then $12 \mathrm{~h}$ for the hydrolysis step at $60{ }^{\circ} \mathrm{C}$, as an exception. Purification by flash column chromatography using cyclohexane/ethyl acetate (6/4) as the eluent afforded compound 38 (54 $\mathrm{mg}, 48 \%$ yield) as a white powder.

Method B: Anhydrous $\mathrm{AlCl}_{3}(111 \mathrm{mg}, 0.83 \mathrm{mmol})$ was added to acetyl chloride $(24 \mu \mathrm{L}, 0.33 \mathrm{mmol})$ in 1,2-dichloroethane $(10 \mathrm{~mL})$. Then, 1,3,7-trimethoxydibenzo[ $b$, $d]$ furan4-carboxamide 39 (see below) in 1,2-dichloroethane $(20 \mathrm{~mL})$ was added slowly and the mixture was left at room temperature for $1 \mathrm{~h}$. After the reaction (TLC control) was completed, the reaction mixture was quenched with $1 \mathrm{~N} \mathrm{HCl}$ and extracted with dichloromethane $(2 \times 25 \mathrm{~mL})$. The combined organic extracts were washed with water, dried over anhydrous sodium sulfate, filtered, and concentrated in vacuum. The crude product obtained was purified over silica gel column chromatography using cyclohexane/ethyl acetate (6/4) as the eluent to obtain the pure product 38 (42 $\mathrm{mg}, 74 \%$ yield).

$R_{\mathrm{f}} 0.59\left(\mathrm{CH}_{2} \mathrm{Cl}_{2} / \mathrm{MeOH} 9: 1\right)$; Mp: $228-229{ }^{\circ} \mathrm{C} ;{ }^{1} \mathrm{H}$ NMR $\left(400 \mathrm{MHz}, \mathrm{DMSO}-d_{6}\right) \delta 8.13$ (s, $\left.1 \mathrm{H}, \mathrm{H}_{9}\right), 7.70\left(\mathrm{~s}, 1 \mathrm{H}, \mathrm{CONH}_{2}\right), 7.54\left(\mathrm{~m}, 2 \mathrm{H}, \mathrm{CONH}_{2}, \mathrm{H}_{6}\right), 6.72\left(\mathrm{~s}, 1 \mathrm{H}, \mathrm{H}_{2}\right), 4.08\left(\mathrm{~s}, 3 \mathrm{H}, \mathrm{CH}_{3}\right)$, $3.97\left(\mathrm{~s}, 3 \mathrm{H}, \mathrm{CH}_{3}\right), 3.93\left(\mathrm{~s}, 3 \mathrm{H}, \mathrm{CH}_{3}\right), 2.58\left(\mathrm{~s}, 3 \mathrm{H}, \mathrm{COCH}_{3}\right) ;{ }^{13} \mathrm{C}$ NMR $\left(100 \mathrm{MHz}, \mathrm{DMSO}-d_{6}\right) \delta$ $197.9\left(\mathrm{COCH}_{3}\right), 164.2\left(\underline{\mathrm{CONH}}_{2}\right), 158.6(\mathrm{C}), 158.3\left(\mathrm{C}_{7}\right), 157.1(\mathrm{C}), 155.1\left(\mathrm{C}_{1}\right), 154.9\left(\mathrm{C}_{3}\right), 124.2$ $\left(\mathrm{C}_{8}\right), 122.1\left(\mathrm{C}_{9}\right), 115.4(\mathrm{C}), 105.5(\mathrm{C}), 105.0\left(\mathrm{C}_{4}\right), 96.0\left(\mathrm{C}_{6}\right), 91.6\left(\mathrm{C}_{2}\right), 56.7\left(\mathrm{CH}_{3}\right), 56.4\left(\mathrm{CH}_{3}\right)$, $56.2\left(\mathrm{CH}_{3}\right), 31.6\left(\mathrm{COCH}_{3}\right) ; \mathrm{IR}\left(\mathrm{cm}^{-1}\right): 3387,3197,1606,1402,1317,1273,1089 ; \mathrm{MS}$ (ESI) $\mathrm{m} / z$ (\%): $344.2(100)[\mathrm{M}+\mathrm{H}]^{+}$; UPLC purity = 98\%, $t_{\mathrm{R}} 2.15 \mathrm{~min}$; HRMS (TOF MS ES+): calcd. for $\mathrm{C}_{18} \mathrm{H}_{18} \mathrm{NO}_{6}[\mathrm{M}+\mathrm{H}]^{+}$344.112864, found: 344.11210 .

\section{1,3,7-Trimethoxydibenzo[ $[b, d]$ furan-4-carboxamide (39)}

The reaction was carried out using 1,3,7-trimethoxydibenzo[b,d]furan $34(100 \mathrm{mg}$, $0.38 \mathrm{mmol})$ and CSI $(67 \mu \mathrm{L}, 0.77 \mathrm{mmol})$ in $\mathrm{CH}_{3} \mathrm{CN}(10 \mathrm{~mL})$ for $6 \mathrm{~h}$ and then $6 \mathrm{~h}$ for the hydrolysis step. Purification by flash column chromatography using cyclohexane/ethyl acetate (6/4) as the eluent afforded compound $39(50 \mathrm{mg}, 44 \%$ yield) as a white powder. $R_{\mathrm{f}} 0.67\left(\mathrm{CH}_{2} \mathrm{Cl}_{2} / \mathrm{MeOH} 9: 1\right)$; $\mathrm{Mp}: 332-333{ }^{\circ} \mathrm{C} ;{ }^{1} \mathrm{H}$ NMR $\left(400 \mathrm{MHz}, \mathrm{DMSO}-d_{6}\right) \delta 7.79(\mathrm{~d}$, $\left.J=8.5 \mathrm{~Hz}, 1 \mathrm{H}, \mathrm{H}_{9}\right), 7.67\left(\mathrm{~s}, 1 \mathrm{H}, \mathrm{CONH}_{2}\right), 7.48\left(\mathrm{~s}, 1 \mathrm{H}, \mathrm{CONH}_{2}\right), 7.30\left(\mathrm{~d}, J=2.3 \mathrm{~Hz}, 1 \mathrm{H}, \mathrm{H}_{6}\right)$, $6.95\left(\mathrm{dd}, J=8.5,2.3 \mathrm{~Hz}, 1 \mathrm{H}, \mathrm{H}_{8}\right), 6.69\left(\mathrm{~s}, 1 \mathrm{H}, \mathrm{H}_{2}\right), 4.07\left(\mathrm{~s}, 3 \mathrm{H}, \mathrm{CH}_{3}\right), 3.92\left(\mathrm{~s}, 3 \mathrm{H}, \mathrm{CH}_{3}\right), 3.84$ $\left(\mathrm{s}, 3 \mathrm{H}, \mathrm{CH}_{3}\right) ;{ }^{13} \mathrm{C}$ NMR $\left(100 \mathrm{MHz}, \mathrm{DMSO}-d_{6}\right) \delta 164.5(\mathrm{C}=\mathrm{O}), 158.2\left(\mathrm{C}_{7}\right), 156.5(\mathrm{C}), 156.1$ $(\mathrm{C}), 154.8\left(\mathrm{C}_{1}\right), 154.4\left(\mathrm{C}_{3}\right), 121.4\left(\mathrm{C}_{9}\right), 115.5(\mathrm{C}), 110.8\left(\mathrm{C}_{8}\right), 106.1\left(\mathrm{C}_{4}\right), 104.9(\mathrm{C}), 96.7\left(\mathrm{C}_{6}\right)$, $91.2\left(\mathrm{C}_{2}\right), 56.7\left(\mathrm{CH}_{3}\right), 56.0\left(\mathrm{CH}_{3}\right), 55.6\left(\mathrm{CH}_{3}\right)$; IR $\left(\mathrm{cm}^{-1}\right): 3377,3192,2970,2839,1643,1610$, $1454,1431,1375,1321,1267,1209,1107,1026$; MS (ESI) $m / z(\%): 302.1(100)[\mathrm{M}+\mathrm{H}]^{+}$; UPLC purity $=99 \%, t_{\mathrm{R}} 2.26 \mathrm{~min}$; HRMS (TOF MS ES+): calcd. for $\mathrm{C}_{16} \mathrm{H}_{16} \mathrm{NO}_{5}[\mathrm{M}+\mathrm{H}]^{+}$ 302.102299, found: 302.10192.

\section{8-Acetyl-1,3-dimethoxydibenzo[ $b, d]$ furan-4-carboxamide (40)}

The reaction was carried out using 1-(7,9-dimethoxydibenzo[ $[b, d]$ furan-2-yl)ethanone $35(200 \mathrm{mg}, 0.74 \mathrm{mmol})$ and CSI $(128 \mu \mathrm{L}, 1.48 \mathrm{mmol})$ in $\mathrm{CH}_{3} \mathrm{CN}(20 \mathrm{~mL})$ for $12 \mathrm{~h}$ and then $12 \mathrm{~h}$ for the hydrolysis step. Purification by flash column chromatography using cyclohexane/ethyl acetate (6/4) as the eluent afforded compound 40 (74 $\mathrm{mg}, 32 \%$ yield) as a yellow powder. $R_{\mathrm{f}} 0.61\left(\mathrm{CH}_{2} \mathrm{Cl}_{2} / \mathrm{MeOH} 9: 1\right) ; \mathrm{Mp}: 237-238{ }^{\circ} \mathrm{C} ;{ }^{1} \mathrm{H} \mathrm{NMR}(400 \mathrm{MHz}$, DMSO-d $\left.d_{6}\right) \delta 8.48\left(\mathrm{~s}, 1 \mathrm{H}, \mathrm{H}_{9}\right), 8.07\left(\mathrm{~d}, J=8.8 \mathrm{~Hz}, 1 \mathrm{H}, \mathrm{H}_{7}\right), 7.90-7.43\left(\mathrm{~m}, 3 \mathrm{H}, \mathrm{H}_{6}, \mathrm{CONH}_{2}\right)$, $6.78\left(\mathrm{~s}, 1 \mathrm{H}, \mathrm{H}_{2}\right), 4.14\left(\mathrm{~s}, 3 \mathrm{H}, \mathrm{CH}_{3}\right), 3.96\left(\mathrm{~s}, 3 \mathrm{H}, \mathrm{CH}_{3}\right), 2.68\left(\mathrm{~s}, 3 \mathrm{H}, \mathrm{CH}_{3}\right) ;{ }^{13} \mathrm{C} \mathrm{NMR}(100 \mathrm{MHz}$, DMSO-d 6$) \delta 197.0\left(\mathrm{COCH}_{3}\right), 164.1\left(\mathrm{CONH}_{2}\right), 158.2\left(\mathrm{C}_{3}\right), 157.5\left(\mathrm{C}_{1}\right), 155.9(\mathrm{C}), 155.1(\mathrm{C})$, $132.6\left(\mathrm{C}_{8}\right), 126.6\left(\mathrm{C}_{7}\right), 122.9(\mathrm{C}), 121.3\left(\mathrm{C}_{9}\right), 110.9\left(\mathrm{C}_{6}\right), 105.3\left(\mathrm{C}_{4}\right), 104.8(\mathrm{C}), 91.6\left(\mathrm{C}_{2}\right), 56.7$ $\left(\mathrm{CH}_{3}\right), 56.3\left(\mathrm{CH}_{3}\right), 26.8\left(\mathrm{COCH}_{3}\right)$; IR $\left(\mathrm{cm}^{-1}\right): 3381,1649,1612,1415,1365,1321,1286,1215$, 
1097; MS (ESI) $m / z(\%): 314.2(100)[\mathrm{M}+\mathrm{H}]^{+}$; UPLC purity $=100 \%, t_{\mathrm{R}} 1.99 \mathrm{~min}$; HRMS (TOF MS ES+): calcd. for $\mathrm{C}_{17} \mathrm{H}_{16} \mathrm{NO}_{5}[\mathrm{M}+\mathrm{H}]^{+}$314.102299, found: 314.10187.

8-Fluoro-1,3-dimethoxydibenzo[ $b, d]$ furan-4-carboxamide (41)

The reaction was carried out using 8-fluoro-1,3-dimethoxydibenzo[ $b, d]$ furan 36 (185 mg, $0.75 \mathrm{mmol})$ and CSI $(130 \mu \mathrm{L}, 1.5 \mathrm{mmol})$ in $\mathrm{CH}_{3} \mathrm{CN}(20 \mathrm{~mL})$ for $12 \mathrm{~h}$ and then $12 \mathrm{~h}$ for the hydrolysis step. Purification by reverse phase column chromatography $\left(\mathrm{C}_{18}\right)$ using water/acetonitrile (7/3) as the eluent afforded, after lyophilization, compound 41 (76 $\mathrm{mg}, 35 \%$ yield) as a white powder. $R_{\mathrm{f}} 0.26$ (AcOEt); Mp: $230-231{ }^{\circ} \mathrm{C} ;{ }^{1} \mathrm{H}$ NMR $\left(400 \mathrm{MHz}, \mathrm{DMSO}-d_{6}\right)$ $\delta 7.71-7.67(\mathrm{~s}, 1 \mathrm{H}, \mathrm{NH}), 7.68\left(\mathrm{dd}, J=8.9,4.1 \mathrm{~Hz}, 1 \mathrm{H}, \mathrm{H}_{6}\right), 7.64\left(\mathrm{dd}, J=8.4,2.7 \mathrm{~Hz}, 1 \mathrm{H}, \mathrm{H}_{9}\right)$, $7.51(\mathrm{~s}, 1 \mathrm{H}, \mathrm{NH}), 7.24\left(\mathrm{dt}, J=8.9,2.7 \mathrm{~Hz}, 1 \mathrm{H}, \mathrm{H}_{7}\right), 6.72\left(\mathrm{~s}, 1 \mathrm{H}, \mathrm{H}_{2}\right), 4.09\left(\mathrm{~s}, 3 \mathrm{H}, \mathrm{CH}_{3}\right), 3.95(\mathrm{~s}$, $\left.3 \mathrm{H}, \mathrm{CH}_{3}\right) ;{ }^{13} \mathrm{C}$ NMR $\left(100 \mathrm{MHz}, \mathrm{DMSO}-d_{6}\right) \delta 164.3(\mathrm{C}=\mathrm{O}), 158.5\left(\mathrm{~d}, \mathrm{~J}_{\mathrm{CF}}=235 \mathrm{~Hz}, \mathrm{C}_{8}\right), 158.2$ $\left(\mathrm{C}_{3}\right), 155.8\left(\mathrm{C}_{1}\right), 155.5\left(\mathrm{C}_{4 \mathrm{a}}\right), 151.1\left(\mathrm{C}_{9 \mathrm{~b}}\right), 123.6\left(\mathrm{~d}, J_{C F}=11 \mathrm{~Hz}, \mathrm{C}_{9 \mathrm{a}}\right), 112.4\left(\mathrm{~d}, J_{C F}=26 \mathrm{~Hz}\right.$, $\left.\mathrm{C}_{7}\right), 112.1\left(\mathrm{~d}, J_{C F}=9 \mathrm{~Hz}, \mathrm{C}_{6}\right), 107.1\left(\mathrm{~d}, J_{C F}=26 \mathrm{~Hz}, \mathrm{C}_{9}\right), 105.8\left(\mathrm{C}_{5 \mathrm{a}}\right), 104.7\left(\mathrm{C}_{4}\right), 91.2\left(\mathrm{C}_{2}\right)$, $56.7\left(\mathrm{CH}_{3}\right), 56.2\left(\mathrm{CH}_{3}\right)$; IR $\left(\mathrm{cm}^{-1}\right)$ : 3381, 1649, 1612, 1415, 1365, 1321, 1286, 1215, 1097; MS (ESI) $m / z(\%): 290.1(100)[\mathrm{M}+\mathrm{H}]^{+}$; UPLC purity $=99 \%, t_{\mathrm{R}} 2.23 \mathrm{~min}$; HRMS (TOF MS ES+): calcd. for $\mathrm{C}_{15} \mathrm{H}_{13} \mathrm{FNO}_{4}[\mathrm{M}+\mathrm{H}]^{+}$290.075037, found: 290.07422 .

\section{1,3-Dimethoxy-8-(trifluoromethyl)dibenzo[ $b, d]$ furan-4-carboxamide (42)}

The reaction was carried out using 1,3-dimethoxy-8-(trifluoromethyl)dibenzo[ $b, d]$ furan 37 (145 mg, $0.50 \mathrm{mmol})$ and CSI $(85 \mu \mathrm{L}, 1.0 \mathrm{mmol})$ in $\mathrm{CH}_{3} \mathrm{CN}(15 \mathrm{~mL})$ for $12 \mathrm{~h}$ then $12 \mathrm{~h}$ for the hydrolysis step. Purification by flash column chromatography using ethyl acetate/methanol (95/5) as the eluent afforded compound 42 (58 $\mathrm{mg}, 35 \%$ yield) as a white powder. $R_{\mathrm{f}} 0.30$ (AcOEt); Mp: $250-251^{\circ} \mathrm{C} ;{ }^{1} \mathrm{H}$ NMR (400 MHz, DMSO-d 6 ) $\delta 8.22$ (d, $\left.J=1.8 \mathrm{~Hz}, 1 \mathrm{H}, \mathrm{H}_{9}\right), 7.90$ (d, $\left.J=8.7 \mathrm{~Hz}, 1 \mathrm{H}, \mathrm{H}_{6}\right), 7.78\left(\mathrm{dd}, J=8.7,1.8 \mathrm{~Hz}, 1 \mathrm{H}, \mathrm{H}_{7}\right), 7.74(\mathrm{~s}, 1 \mathrm{H}, \mathrm{NH}), 7.59(\mathrm{~s}, 1 \mathrm{H}, \mathrm{NH}), 6.81$ $\left(\mathrm{s}, 1 \mathrm{H}, \mathrm{H}_{2}\right), 4.17\left(\mathrm{~s}, 3 \mathrm{H}, \mathrm{CH}_{3}\right), 4.02\left(\mathrm{~s}, 3 \mathrm{H}, \mathrm{CH}_{3}\right) ;{ }^{13} \mathrm{C}$ NMR $\left(100 \mathrm{MHz}, \mathrm{DMSO}-d_{6}\right) \delta 164.1(\mathrm{C}=\mathrm{O})$, 158.6 $\left(\mathrm{C}_{3}\right), 156.6\left(\mathrm{C}_{4 \mathrm{a}}\right), 156.1\left(\mathrm{C}_{1}\right), 155.3\left(\mathrm{C}_{9 \mathrm{~b}}\right), 125.9\left(\mathrm{C}_{8}\right), 124.2\left(\mathrm{q}, J_{C F}=310 \mathrm{~Hz}, \mathrm{CF}_{3}\right), 123.2\left(\mathrm{C}_{9 \mathrm{a}}\right)$, $122.5\left(\mathrm{q}, J_{C F}=4 \mathrm{~Hz}, \mathrm{C}_{7}\right), 118.1\left(\mathrm{q}, J_{C F}=4 \mathrm{~Hz}, \mathrm{C}_{9}\right), 111.8\left(\mathrm{C}_{6}\right), 105.0\left(\mathrm{C}_{5 \mathrm{a}}\right), 104.6\left(\mathrm{C}_{4}\right), 91.6\left(\mathrm{C}_{2}\right)$, $56.7\left(\mathrm{CH}_{3}\right), 56.3\left(\mathrm{CH}_{3}\right)$; IR ( $\left.\mathrm{cm}^{-1}\right)$ : IR: 3379, 3179, 2974, 1649, 1618, 1319, 1115, 814; MS (ESI) $\mathrm{m} / z$ (\%): $340.1(100)[\mathrm{M}+\mathrm{H}]^{+}$; UPLC purity = 98\%, $t_{\mathrm{R}} 2.64 \mathrm{~min}$; HRMS (TOF MS ES+): calcd. for $\mathrm{C}_{16} \mathrm{H}_{13} \mathrm{~F}_{3} \mathrm{NO}_{4}[\mathrm{M}+\mathrm{H}]^{+}$340.071843, found: 340.07112 .

\subsubsection{General Procedure for the Preparation of 1,3-hydroxydibenzofuran-4-carboxamide 43-47}

A mixture of 1,3-dimethoxydibenzofuran-4-carboxamides 38-42 (50 mg) in warm pyridine hydrochloride $(3 \mathrm{~g})$ was irradiated using microwave $(100 \mathrm{~W})$ heating at $200{ }^{\circ} \mathrm{C}$ for $15 \mathrm{~min}$. After the addition of water, the mixture was extracted with ethyl acetate (100 $\mathrm{mL}$ ). The organic layers were washed with brine, dried over sodium sulfate, filtered, and evaporated to dryness. The crude product was then purified by chromatography to provide 43-47.

\section{8-Acetyl-1,3,7-trihydroxydibenzo[ $b, d]$ furan-4-carboxamide (43)}

The reaction was carried out using 8-acetyl-1,3,7-trimethoxydibenzo[ $b, d]$ furan-4- carboxamide 38 (50 mg, $0.15 \mathrm{mmol}$ ) in warm pyridine hydrochloride ( $3 \mathrm{~g})$. Purification by flash column chromatography using dichloromethane as the eluent afforded compound 43 (17 mg, 39\% yield) as a brown powder. $R_{\mathrm{f}} 0.53\left(\mathrm{CH}_{2} \mathrm{Cl}_{2} / \mathrm{MeOH} 9: 1\right)$; $\mathrm{Mp}$ : 335-336 ${ }^{\circ} \mathrm{C}$; ${ }^{1} \mathrm{H}$ NMR (400 MHz, DMSO-d 6 ) $\delta 13.82$ (s, 1H, OH), $12.44(\mathrm{~s}, 1 \mathrm{H}, \mathrm{OH}), 11.38(\mathrm{~s}, 1 \mathrm{H}, \mathrm{OH})$, $8.30\left(\mathrm{~m}, 2 \mathrm{H}, \mathrm{H}_{9}, \mathrm{CONH}_{2}\right), 7.81\left(\mathrm{~s}, 1 \mathrm{H}, \mathrm{CONH}_{2}\right), 7.25\left(\mathrm{~s}, 1 \mathrm{H}, \mathrm{H}_{6}\right), 6.32\left(\mathrm{~s}, 1 \mathrm{H}, \mathrm{H}_{2}\right), 2.74(\mathrm{~s}$, $\left.3 \mathrm{H}, \mathrm{COCH}_{3}\right) ;{ }^{13} \mathrm{C} \mathrm{NMR}\left(100 \mathrm{MHz}, \mathrm{DMSO}-d_{6}\right) \delta 203.7\left(\mathrm{COCH}_{3}\right), 169.7\left(\mathrm{CONH}_{2}\right), 163.7\left(\mathrm{C}_{7}\right)$, $160.1\left(\mathrm{C}_{3}\right), 158.8(\mathrm{C}), 157.0\left(\mathrm{C}_{1}\right), 155.7(\mathrm{C}), 123.3\left(\mathrm{C}_{9}\right), 117.4(\mathrm{C}), 115.5\left(\mathrm{C}_{8}\right), 103.5\left(\mathrm{C}_{4}\right), 99.8$ $\left(\mathrm{C}_{2}\right), 98.5\left(\mathrm{C}_{6}\right), 93.0(\mathrm{C}), 27.8\left(\mathrm{COCH}_{3}\right) ; \mathrm{IR}\left(\mathrm{cm}^{-1}\right): 3462,3334,3170,1614,1469,1396,1246$, 1103, 1041; MS (ESI) $m / z(\%): 302.1(100)[\mathrm{M}+\mathrm{H}]^{+}$; UPLC purity $=99 \%, t_{\mathrm{R}} 2.17 \mathrm{~min}$; HRMS (TOF MS ES+): calcd. for $\mathrm{C}_{15} \mathrm{H}_{12} \mathrm{NO}_{6}[\mathrm{M}+\mathrm{H}]^{+} 302.065914$, found: 302.06557 . 


\section{1,3,7-Trihydroxydibenzo[ $b, d]$ furan-4-carboxamide (44)}

The reaction was carried out using 1,3,7-trimethoxydibenzo[b,d]furan-4-carboxamide 39 (50 mg, $0.17 \mathrm{mmol}$ ) in warm pyridine hydrochloride ( $3 \mathrm{~g}$ ). Purification by flash column chromatography using cyclohexane/ethyl acetate (6/4) as the eluent afforded compound $44(16 \mathrm{mg}, 38 \%$ yield) as a brown powder. $R_{\mathrm{f}} 0.67\left(\mathrm{CH}_{2} \mathrm{Cl}_{2} / \mathrm{MeOH}\right.$ 9:1); $\mathrm{Mp}$ : $360-361{ }^{\circ} \mathrm{C} ;{ }^{1} \mathrm{H} \mathrm{NMR}(400 \mathrm{MHz}$, DMSO- $\left._{6}\right) \delta 13.73(\mathrm{~s}, 1 \mathrm{H}, \mathrm{OH}), 11.09(\mathrm{~s}, 1 \mathrm{H}, \mathrm{OH}), 9.75(\mathrm{~s}, 1 \mathrm{H}, \mathrm{OH}), 8.20\left(\mathrm{~s}, 1 \mathrm{H}, \mathrm{CONH}_{2}\right), 7.80(\mathrm{~s}$, $\left.1 \mathrm{H}, \mathrm{CONH}_{2}\right), 7.68\left(\mathrm{~d}, J=8.5 \mathrm{~Hz}, 1 \mathrm{H}, \mathrm{H}_{9}\right), 7.10\left(\mathrm{~s}, 1 \mathrm{H}, \mathrm{H}_{6}\right), 6.81\left(\mathrm{~d}, J=8.3 \mathrm{~Hz}, 1 \mathrm{H}, \mathrm{H}_{8}\right), 6.25(\mathrm{~s}, 1 \mathrm{H}$, $\left.\mathrm{H}_{2}\right) ;{ }^{13} \mathrm{C}$ NMR $\left(100 \mathrm{MHz}\right.$, DMSO-d $\left.d_{6}\right) \delta 170.1(\mathrm{C}=\mathrm{O}), 162.8\left(\mathrm{C}_{7}\right), 156.7\left(\mathrm{C}_{3}\right), 155.7\left(\mathrm{C}_{1}\right), 155.5(\mathrm{C})$, 154.9 (C), $121.1\left(\mathrm{C}_{9}\right), 114.4(\mathrm{C}), 112.0\left(\mathrm{C}_{8}\right), 104.7\left(\mathrm{C}_{4}\right), 98.5\left(\mathrm{C}_{2}\right), 97.8\left(\mathrm{C}_{6}\right), 92.7(\mathrm{C}) ; \mathrm{IR}\left(\mathrm{cm}^{-1}\right): 3423$, $3321,3242,3219,1664,1556,1502,1446,1288,1257,1190,1107,1029$; MS (ESI) $m / z$ (\%): 260.1 (100) $[\mathrm{M}+\mathrm{H}]^{+}$; UPLC purity $=100 \%, t_{\mathrm{R}} 1.64 \mathrm{~min}$; HRMS (TOF MS ES+): calcd. for $\mathrm{C}_{13} \mathrm{H}_{10} \mathrm{NO}_{5}[\mathrm{M}+$ $\mathrm{H}]^{+} 260.055349$, found: 260.05591 .

8-Acetyl-1,3-dihydroxydibenzo[ $b, d]$ furan-4-carboxamide (45)

The reaction was carried out using 8-acetyl-1,3-dimethoxydibenzo[b,d]furan-4- carboxamide 40 (50 $\mathrm{mg}, 0.16 \mathrm{mmol})$ in warm pyridine hydrochloride $(3 \mathrm{~g})$. Purification by flash column chromatography using cyclohexane/ethyl acetate (6/4) as the eluent afforded compound 45 (12 mg, $26 \%$ yield) as a yellow powder. $R_{\mathrm{f}} 0.56\left(\mathrm{CH}_{2} \mathrm{Cl}_{2} / \mathrm{MeOH}\right.$ 9:1); $\mathrm{Mp}$ : $355-356{ }^{\circ} \mathrm{C} ;{ }^{1} \mathrm{H}$ NMR $\left(400 \mathrm{MHz}, \mathrm{DMSO}-d_{6}\right) \delta 13.98(\mathrm{~s}, 1 \mathrm{H}, \mathrm{OH}), 11.54(\mathrm{~s}, 1 \mathrm{H}, \mathrm{OH}), 8.47$ $\left(\mathrm{d}, J=1.9 \mathrm{~Hz}, 1 \mathrm{H}, \mathrm{H}_{9}\right), 8.32\left(\mathrm{~s}, 1 \mathrm{H}, \mathrm{CONH}_{2}\right), 8.06\left(\mathrm{dd}, J=8.6,2.0 \mathrm{~Hz}, 1 \mathrm{H}, \mathrm{H}_{7}\right), 7.88(\mathrm{~s}, 1 \mathrm{H}$, $\left.\mathrm{CONH}_{2}\right), 7.81\left(\mathrm{~d}, J=8.6 \mathrm{~Hz}, 1 \mathrm{H}, \mathrm{H}_{6}\right), 6.36\left(\mathrm{~s}, 1 \mathrm{H}, \mathrm{H}_{2}\right), 2.68\left(\mathrm{~s}, 3 \mathrm{H}, \mathrm{COCH}_{3}\right) ;{ }^{13} \mathrm{C} \mathrm{NMR}$ $\left(100 \mathrm{MHz}, \mathrm{DMSO}-d_{6}\right) \delta 197.0\left(\mathrm{COCH}_{3}\right), 169.8\left(\mathrm{CONH}_{2}\right), 164.8\left(\mathrm{C}_{3}\right), 157.8\left(\mathrm{C}_{1}\right), 156.8(\mathrm{C})$, $156.0(\mathrm{C}), 133.0\left(\mathrm{C}_{8}\right), 125.9\left(\mathrm{C}_{7}\right), 123.2(\mathrm{C}), 121.0\left(\mathrm{C}_{9}\right), 111.3\left(\mathrm{C}_{6}\right), 103.9\left(\mathrm{C}_{4}\right), 98.4\left(\mathrm{C}_{2}\right), 92.8$ (C), $26.8\left(\mathrm{COCH}_{3}\right) ; \mathrm{IR}\left(\mathrm{cm}^{-1}\right)$ : 3479, 3190, 1600, 1415, 1359, 1284, 1249, 1190, 1045; MS (ESI) $m / z(\%): 286.1(100)[\mathrm{M}+\mathrm{H}]^{+}$; UPLC purity $=99 \%, t_{\mathrm{R}} 2.04 \mathrm{~min}$; HRMS (TOF MS ES + ): calcd. for $\mathrm{C}_{15} \mathrm{H}_{12} \mathrm{NO}_{5}[\mathrm{M}+\mathrm{H}]^{+}$286.070999, found: 286.07079 .

\section{8-Fluoro-1,3-dihydroxydibenzo[b,d]furan-4-carboxamide (46)}

The reaction was carried out using 8-fluoro-1,3-dimethoxydibenzo[ $b, d]$ furan-4- carboxamide 41 (50 mg, $0.17 \mathrm{mmol}$ ) in warm pyridine hydrochloride (3g). Purification by flash column chromatography using cyclohexane/ethyl acetate $(6 / 4)$ as the eluent afforded compound 46 (23 mg, 51\% yield) as a beige powder. $R_{\mathrm{f}} 0.39$ (cyHex/AcOEt 6:4); Mp: $342-343{ }^{\circ} \mathrm{C} ;{ }^{1} \mathrm{H}$ NMR $\left(400 \mathrm{MHz}, \mathrm{DMSO}-d_{6}\right) \delta 13.99(\mathrm{~s}, 1 \mathrm{H}, \mathrm{OH}), 11.54(\mathrm{~s}, 1 \mathrm{H}, \mathrm{OH}), 8.29(\mathrm{~s}$, $1 \mathrm{H}, \mathrm{NH}), 7.82(\mathrm{~s}, 1 \mathrm{H}, \mathrm{NH}), 7.71\left(\mathrm{dd}, J=8.8,4.0 \mathrm{~Hz}, 1 \mathrm{H}, \mathrm{H}_{6}\right), 7.60(\mathrm{dd}, J=8.4,2.8 \mathrm{~Hz}, 1 \mathrm{H}$, $\left.\mathrm{H}_{9}\right), 7.21\left(\mathrm{dt}, J=8.8,2.8 \mathrm{~Hz}, 1 \mathrm{H}, \mathrm{H}_{7}\right), 6.33\left(\mathrm{~s}, 1 \mathrm{H}, \mathrm{H}_{2}\right) ;{ }^{13} \mathrm{C}$ NMR $\left(100 \mathrm{MHz}, \mathrm{DMSO}-d_{6}\right) \delta$ $170.0(\mathrm{C}=\mathrm{O}), 165.0\left(\mathrm{C}_{3}\right), 158.8\left(\mathrm{~d}, J_{C F}=236 \mathrm{~Hz}, \mathrm{C}_{8}\right), 158.1\left(\mathrm{C}_{1}\right), 156.4\left(\mathrm{C}_{4 \mathrm{a}}\right), 150.4\left(\mathrm{C}_{9 \mathrm{~b}}\right), 124.0$ $\left(\mathrm{d}, J_{C F}=11 \mathrm{~Hz}, \mathrm{C}_{9 \mathrm{a}}\right), 112.4\left(\mathrm{~d}, J_{C F}=9 \mathrm{~Hz}, \mathrm{C}_{6}\right), 111.7\left(\mathrm{~d}, J_{C F}=26 \mathrm{~Hz}, \mathrm{C}_{7}\right), 106.7\left(\mathrm{~d}, J_{C F}=26\right.$ $\left.\mathrm{Hz}, \mathrm{C}_{9}\right), 104.3\left(\mathrm{~d}, J_{\mathrm{CF}}=3 \mathrm{~Hz}, \mathrm{C}_{5 \mathrm{a}}\right), 98.1\left(\mathrm{C}_{4}\right), 92.6\left(\mathrm{C}_{2}\right) ; \mathrm{IR}\left(\mathrm{cm}^{-1}\right): 3481,3188,3098,1628$, $1474,1410,1161,802 ; \mathrm{MS}$ (ESI) $m / z(\%): 262.1(100)[\mathrm{M}+\mathrm{H}]^{+} ;$UPLC purity $=99 \%, t_{\mathrm{R}} 2.28$ min; HRMS (TOF MS ES+): calcd. for $\mathrm{C}_{13} \mathrm{H}_{9} \mathrm{FNO}_{4}[\mathrm{M}+\mathrm{H}]^{+} 262.043737$, found: 262.04354 .

\section{1,3-Dihydroxy-8-(trifluoromethyl)dibenzo[ $b, d]$ furan-4-carboxamide (47)}

The reaction was carried out using 1,3-dimethoxy-8-(trifluoromethyl)dibenzo[ $[b, d]$ furan4-carboxamide 42 ( $50 \mathrm{mg}, 0.15 \mathrm{mmol}$ ) in warm pyridine hydrochloride ( $3 \mathrm{~g})$. Purification by flash column chromatography using cyclohexane/ethyl acetate (6/4) as the eluent afforded compound 47 ( $24 \mathrm{mg}, 53 \%$ yield) as a beige powder. $R_{\mathrm{f}} 0.40$ (cyHex/AcOEt 6:4); Mp: $347-348{ }^{\circ} \mathrm{C} ;{ }^{1} \mathrm{H}$ NMR $\left(400 \mathrm{MHz}, \mathrm{DMSO}-d_{6}\right) \delta 13.99(\mathrm{~s}, 1 \mathrm{H}, \mathrm{OH}), 11.98(\mathrm{~s}, 1 \mathrm{H}, \mathrm{OH}), 8.33$ (s, $1 \mathrm{H}, \mathrm{NH}), 8.14\left(\mathrm{~d}, J=1.6 \mathrm{~Hz}, 1 \mathrm{H}, \mathrm{H}_{9}\right), 7.90\left(\mathrm{~d}, J=8.8 \mathrm{~Hz}, 1 \mathrm{H}, \mathrm{H}_{6}\right), 7.87(\mathrm{~s}, 1 \mathrm{H}, \mathrm{NH}), 7.74(\mathrm{dd}$, $\left.J=8.8,1.6 \mathrm{~Hz}, 1 \mathrm{H}, \mathrm{H}_{7}\right), 6.53\left(\mathrm{~s}, 1 \mathrm{H}, \mathrm{H}_{2}\right) ;{ }^{13} \mathrm{C}$ NMR $\left(100 \mathrm{MHz}, \mathrm{DMSO}-d_{6}\right) \delta 169.8(\mathrm{C}=\mathrm{O})$, $165.1\left(\mathrm{C}_{3}\right), 158.3\left(\mathrm{C}_{1}\right), 156.1\left(\mathrm{C}_{4 \mathrm{a}}\right), 155.9\left(\mathrm{C}_{9 \mathrm{~b}}\right), 125.9\left(\mathrm{C}_{8}\right), 124.6\left(\mathrm{q}, J_{\mathrm{CF}}=310 \mathrm{~Hz}, \mathrm{CF}_{3}\right), 123.6$ $\left(\mathrm{C}_{9 \mathrm{a}}\right), 121.9\left(\mathrm{q}, J_{\mathrm{CF}}=4 \mathrm{~Hz}, \mathrm{C}_{7}\right), 117.6\left(\mathrm{q}, J_{C F}=4 \mathrm{~Hz}, \mathrm{C}_{9}\right), 112.3\left(\mathrm{C}_{6}\right), 103.6\left(\mathrm{C}_{5 \mathrm{a}}\right), 98.7\left(\mathrm{C}_{4}\right)$, $92.6\left(\mathrm{C}_{2}\right)$; IR ( $\left.\mathrm{cm}^{-1}\right): 3474,3217,1632,1308,1109,887,818 ; \mathrm{MS}$ (ESI) $\mathrm{m} / z$ (\%): 312.1 (100) [M $+\mathrm{H}^{+}$; UPLC purity $=99 \%, t_{\mathrm{R}} 2.58 \mathrm{~min}$; HRMS (TOF MS ES+): calcd. for $\mathrm{C}_{14} \mathrm{H}_{9} \mathrm{~F}_{3} \mathrm{NO}_{4}[\mathrm{M}+$ $\mathrm{H}]^{+}$312.040543, found: 312.04098. 
3.1.8. Access to Dibenzofuran Derivative 19 by Intramolecular C-O Bond Formation from 2-Aryl Phenol 49

2-Hydroxy-3-iodo-4,6-dimethoxybenzamide (48)

A solution of 2-hydroxy-4,6-dimethoxybenzamide $2(200 \mathrm{mg}, 1.01 \mathrm{mmol})$ in dichloromethane $(10 \mathrm{~mL})$ at $0{ }^{\circ} \mathrm{C}$ under argon was added $N$-iodosuccinimide $(230 \mathrm{mg}, 1.01 \mathrm{mmol})$ and the reaction mixture was maintained at this temperature for $10 \mathrm{~min}$. The reaction was diluted with water $(30 \mathrm{~mL})$ and extracted with dichloromethane $(3 \times 50 \mathrm{~mL})$. The combined organic extracts were dried over sodium sulfate and filtered. The solvent was evaporated in vacuo and the residue was purified by silica gel column chromatography using cyclohexane/ethyl acetate (6/4) as the eluent to give compound 48 as a white powder (196 mg, 60\% yield). $R_{\mathrm{f}} 0.21$ (cyHex/AcOEt 6:4); Mp: 270-271 ${ }^{\circ} \mathrm{C} ;{ }^{1} \mathrm{H}$ NMR (400 MHz, DMSO-d 6 ) $\delta 15.74(\mathrm{~s}, 1 \mathrm{H}, \mathrm{OH}), 8.13\left(\mathrm{~s}, 1 \mathrm{H}, \mathrm{CONH}_{2}\right), 8.13(\mathrm{~s}, 1 \mathrm{H}$, $\left.\mathrm{CONH}_{2}\right), 6.30\left(\mathrm{~s}, 1 \mathrm{H}, \mathrm{H}_{5}\right), 3.97\left(\mathrm{~s}, 3 \mathrm{H}, \mathrm{CH}_{3}\right), 3.92\left(\mathrm{~s}, 3 \mathrm{H}, \mathrm{CH}_{3}\right) ;{ }^{13} \mathrm{C} \mathrm{NMR}\left(100 \mathrm{MHz}, \mathrm{DMSO}-d_{6}\right) \delta$ $171.3(\mathrm{C}=\mathrm{O}), 163.9\left(\mathrm{C}_{2}\right), 162.1\left(\mathrm{C}_{6}\right), 161.2\left(\mathrm{C}_{4}\right), 97.1\left(\mathrm{C}_{1}\right), 87.5\left(\mathrm{C}_{5}\right), 67.1\left(\mathrm{C}_{3}\right), 56.5\left(\mathrm{CH}_{3}\right), 56.4\left(\mathrm{CH}_{3}\right)$; IR $\left(\mathrm{cm}^{-1}\right)$ : 3439, 1602, 1579, 1415, 1396, 1336, 1286, 1215, 1120, 1078; MS (ESI) $m / z$ (\%): 324.0 (100) $[\mathrm{M}+\mathrm{H}]^{+}$; UPLC purity $=98 \%, t_{\mathrm{R}} 2.25 \mathrm{~min}$.

\section{2'-Fluoro-2-hydroxy-4,6-dimethoxybiphenyl-3-carboxamide (49)}

2-Hydroxy-3-iodo-4,6-dimethoxybenzamide 48 (1.00 g, $3.1 \mathrm{mmol})$, 2-fluorophenylboronic acid $(650 \mathrm{mg}, 4.7 \mathrm{mmol})$ and potassium phosphate $(1.33 \mathrm{~g}, 6.2 \mathrm{mmol})$ were added to degassed acetonitrile $(16 \mathrm{~mL})$ and water $(4 \mathrm{~mL})$. After stirring for $10 \mathrm{~min}$, palladium(II) acetate $(35 \mathrm{mg}$, 0.05 equiv.) and triphenylphosphine ( $40 \mathrm{mg}, 0.05$ equiv.) were added to the mixture. The tube was then sealed, and the reaction mixture was irradiated using microwave heating at $90{ }^{\circ} \mathrm{C}$ for $2 \mathrm{~h}$. Acetonitrile was removed, the crude product was extracted with ethyl acetate $(100 \mathrm{~mL})$ and washed with water $(2 \times 100 \mathrm{~mL})$, dried over sodium sulfate, filtered, and concentrated under reduced pressure. The crude product was purified by flash silica gel column chromatography using cyclohexane/ethyl acetate (6/4) as the eluent to afford compound $48(234 \mathrm{mg}, 26 \%)$ as a brown powder. $R_{\mathrm{f}} 0.41\left(\mathrm{CH}_{2} \mathrm{Cl}_{2} / \mathrm{MeOH} 9: 1\right)$; $\mathrm{Mp}: 223-224{ }^{\circ} \mathrm{C} ;{ }^{1} \mathrm{H}$ NMR (400 MHz, DMSO- $\left.d_{6}\right)$ $\delta 14.92(\mathrm{~s}, 1 \mathrm{H}, \mathrm{OH}), 8.13\left(\mathrm{~s}, 1 \mathrm{H}, \mathrm{CONH}_{2}\right), 8.03\left(\mathrm{~s}, 1 \mathrm{H}, \mathrm{CONH}_{2}\right), 7.34(\mathrm{~d}, J=7.0 \mathrm{~Hz}, 1 \mathrm{H}), 7.26-6.95$ $(\mathrm{m}, 3 \mathrm{H}), 6.32\left(\mathrm{~s}, 1 \mathrm{H}, \mathrm{H}_{5}\right), 4.00\left(\mathrm{~s}, 3 \mathrm{H}, \mathrm{CH}_{3}\right), 3.78\left(\mathrm{~s}, 3 \mathrm{H}, \mathrm{CH}_{3}\right) . ;{ }^{13} \mathrm{C} \mathrm{NMR}\left(100 \mathrm{MHz}, \mathrm{DMSO}-d_{6}\right) \delta$ $171.9(\mathrm{C}=\mathrm{O}), 162.5\left(\mathrm{C}_{2}\right), 160.9\left(\mathrm{C}_{6}\right), 160.5\left(\mathrm{C}_{4}\right), 158.8\left(\mathrm{~d}, J=243 \mathrm{~Hz}, \mathrm{C}_{2^{\prime}}-\mathrm{F}\right), 133.3\left(\mathrm{~d}, J=4 \mathrm{~Hz}, \mathrm{C}_{6^{\prime}}\right)$, $128.8\left(\mathrm{~d}, J=9 \mathrm{~Hz}, \mathrm{C}_{4^{\prime}}\right), 123.60\left(\mathrm{~d}, J=4 \mathrm{~Hz}, \mathrm{C}_{5^{\prime}}\right), 121.18\left(\mathrm{~d}, J=17 \mathrm{~Hz}, \mathrm{C}_{1^{\prime}}\right), 115.0\left(\mathrm{~d}, J=22 \mathrm{~Hz}, \mathrm{C}_{3^{\prime}}\right)$, $104.4\left(\mathrm{C}_{1}\right), 96.5\left(\mathrm{C}_{3}\right), 86.8\left(\mathrm{C}_{5}\right), 56.2\left(\mathrm{CH}_{3}\right), 55.7\left(\mathrm{CH}_{3}\right)$; IR $\left(\mathrm{cm}^{-1}\right): 3435,1649,1604,1591,1415$, 1317, 1209, 1138, 1114; MS (ESI) $m / z$ (\%): $292.2(100)[\mathrm{M}+\mathrm{H}]^{+} ; \mathrm{UPLC}$ purity $=98 \%, t_{\mathrm{R}} 2.52 \mathrm{~min}$.

\section{1,3-Dimethoxydibenzo[ $b, d]$ furan-4-carboxamide (19)}

For the cyclisation step, see above, Method B.

\subsection{Molecular Modeling}

Molecular modeling studies were performed using SYBYL-X 1.3 software [62] running on a Dell precision T3400 workstation. The three-dimensional structures of compound 44 (most active compound), compound 43 (strict analogue of cercosporamide), and cercosporamide were built from a standard fragments library and optimized using the Tripos force field [63] including the electrostatic term calculated from Gasteiger and Hückel atomic charges. Powell's method available in the Maximin2 procedure was used for energy minimization until the gradient value was smaller than $0.001 \mathrm{kcal} /\left(\mathrm{mol}^{*} \AA\right)$. The crystal structure of Pim-1 in complex with AMP-PNP at 1.6 ̊ resolution (PDB ID 3A99) [64] was used as a template for docking. Water molecules were removed from the coordinates set since no information about conserved water molecules is known for this chemical series in Pim-1. Flexible docking of compounds 44, 43, and cercosporamide into the ATP-binding site was performed using GOLD software [65]. The most stable docking models were selected according to the best scored conformation predicted by the ChemScore scoring function implemented in GOLD. Finally, the complexes were energy-minimized using Powell's method available in the Maximin2 procedure with the Tripos force field and a dielectric 
constant of 4.0, until the gradient value reached $0.1 \mathrm{kcal} / \mathrm{mol}$. $\mathrm{A}$. Biovia Discovery Studio Visualizer [66] was used for graphical display.

\subsection{Biology}

\subsubsection{Mammalian Protein Kinase Assays}

Kinase enzymatic activities were assayed with $10 \mu \mathrm{M}$ ATP in 384-well plates using the luminescent ADP-Glo ${ }^{\mathrm{TM}}$ assay (Promega, Madison, WI, USA) according to the recommendations of the manufacturer (see [56] for details on this method). The transmitted signal was measured using the Envision (PerkinElmer, Waltham, MA, USA) microplate luminometer and expressed in relative light unit (RLU). In order to determine the half maximal inhibitory concentration $\left(\mathrm{IC}_{50}\right)$, the assays were performed in duplicate in the absence or presence of increasing doses of the tested compounds. GraphPad Prism6 software (GraphPad Software, San Diego, CA, USA) was used to fit dose-response curves and to determine the $\mathrm{IC}_{50}$ values. Kinase activities are expressed in \% of maximal activity, i.e., measured in the absence of inhibitor. Peptide substrates were obtained from Proteogenix (Schiltigheim, France).

The following kinases were analyzed during this study: HsPim-1 and HsPim-2 (human proto-oncogene, recombinant, expressed in bacteria) were assayed with $0.20 \mu \mathrm{g} / \mu \mathrm{L}$ of consensus peptide substrate: ARKRRRHPSGPPTA; RnDYRK1A-kd (Rattus norvegicus, amino acids 1 to 499 including the kinase domain, recombinant, expressed in bacteria, DNA vector kindly provided by Dr. W. Becker, Aachen, Germany) was assayed with $0.033 \mu \mathrm{g} / \mu \mathrm{L}$ of the following peptide: KKISGRLSPIMTEQ as substrate; $\mathrm{HsCDK5/ \textrm {p } 2 5}$ (human cyclin-dependent kinase-5, recombinant, expressed in bacteria) was assayed with $0.8 \mu \mathrm{g} / \mu \mathrm{L}$ of histone $\mathrm{H} 1$ as substrate; $\mathrm{Hs}_{s} \mathrm{CDK} 9 / \mathrm{CyclinT}$ (human cyclin-dependent kinase-9, recombinant, expressed by baculovirus in Sf9 insect cells) was assayed with $0.20 \mu \mathrm{g} / \mu \mathrm{L}$ of the following peptide: YSPTSPSYSPTSPSYSPTSPSKKKK, as substrate; HsHaspin-kd (human, kinase domain, amino acids 470 to 798, recombinant, expressed in bacteria) was assayed with $0.007 \mu \mathrm{g} / \mu \mathrm{L}$ of Histone H3 (1-21) peptide (ARTKQTARKSTGGKAPRKQLA) as substrate; MmCLK1 (from Mus musculus, recombinant, expressed in bacteria) was assayed with $0.027 \mu \mathrm{g} / \mu \mathrm{L}$ of the following peptide: GRSRSRSRSRSR as substrate; $\mathrm{Hs}_{s} \mathrm{CK} 1 \varepsilon$ (human casein kinase $1 \varepsilon$, recombinant, expressed by baculovirus in Sf9 insect cells) was assayed with $0.02 \mu \mathrm{g} / \mu \mathrm{L}$ of the following peptide: RRKHAAIGSpAYSITA ("Sp" stands for phosphorylated serine) as the CK1-specific substrate; HsGSK-3 $\beta$ (human glycogen synthase kinase-3) was assayed with $0.010 \mu \mathrm{g} / \mu \mathrm{L}$ of GS-1 peptide, a GSK-3-selective substrate (YRRAAVPPSPSLSRHSSPHQSpEDEEE). For kinases expressed in bacteria, the Escherichia coli BL21 DE3 pLysS strain (Invitrogen, ThermoFisher Scientific, Waltham, MA, USA) was transformed with pGEX-2T-1 (Sigma-Aldrich, St. Louis, MO, USA) containing the coding region of the corresponding kinase. For kinases expressed in Sf9 insect cells, the coding region of the corresponding kinase was cloned in $\mathrm{pFastBac}{ }^{\mathrm{TM}}$ vector. Purification of the recombinant kinases was performed following the protocol "Bac-to-Bac ${ }^{\circledR}$ Baculovirus Expression System" provided by the manufacturer (Invitrogen, ThermoFisher Scientific, Waltham, MA, USA).

To validate the kinase assay, model inhibitors were used for each tested enzyme: Staurosporine from Streptomyces sp. (\#S5921, purity $\geq 95 \%$, Sigma-Aldrich) for $H s C K 1 \varepsilon$; Indirubin-30-oxime (\#I0404, purity $\geq 98 \%$, Sigma-Aldrich) for HsGSK-3 $\beta, H s$ Pim- 1 and 2, human cyclin-dependent kinases, RnDYRK1A and MmCLK1; CHR-6494 (\#SML0648, purity $\geq 98 \%$, Sigma-Aldrich) for Haspin.

\subsubsection{Cell Cultures and Reagents}

MV4-11, K562, and KU812 cell lines were obtained from the Deutshe Sammlung von Mikroorganismens und Zellkulturen (DSMZ) and maintained according to the supplier's recommendations. All cell lines were cultured in RPMI, with 10\% fetal bovine serum, $1 \%$ glutamine, and $1 \%$ penicillin/ streptomycin at $37^{\circ} \mathrm{C}$ and $5 \% \mathrm{CO}_{2}$. 
The cancer cell lines MCF-7, HT-29, and HeLa were obtained from Cell Bank of Rio de Janeiro, Brazil, and were grown in RPMI-1640 medium and L929 cells were grown in Dulbecco's Modified Eagle's Medium (DMEM). Both media were supplemented with fetal bovine serum (FBS) (10\% of the final concentration) followed by treatment with penicillin and streptomycin as antibiotics ( $1 \%$ of the final concentration). The crude was incubated in the presence of $\mathrm{CO}_{2}$ atmosphere $(5 \%)$ for $24 \mathrm{~h}$ with the temperature monitored and maintained at $37^{\circ} \mathrm{C}$.

\subsubsection{In Vitro Cell-Based Assays}

MV4-11, K562, and KU812 cells' viability was studied using a MTT cell proliferation assay. To determine the concentration effect of the molecules, $0.2 \times 10^{6}$ leukemic cells were incubated in $100 \mu \mathrm{L}$ of RPMI red phenol-free medium (Gibco), in 96-well plates and treated with compounds 15-17 and 43-47 (stock solution at $50 \mathrm{mM}$ in DMSO) or the positive control SGI-1776 from SAB Signalway antibody with concentrations ranging from $100 \mathrm{nM}$ to $100 \mu \mathrm{M}$ for $48 \mathrm{~h}$.

MV4-11, K562, and KU812 cells were incubated with $10 \mu \mathrm{L}$ of MTT working solution ( $5 \mathrm{~g} / \mathrm{L}$ of methylthiazolyldiphenyl-tetrazolium bromide from Sigma Aldrich, Lyon, France) for $4 \mathrm{~h}$. Cells were then lysed overnight at $37^{\circ} \mathrm{C}$ with $100 \mu \mathrm{L}$ of $10 \%$ SDS and $0.003 \% \mathrm{HCl}$. Optical density (OD) at $570 \mathrm{~nm}$ was measured using a spectrophotometer CLARIOstar ${ }^{\circledR}$ (BMG Labtech, Offenburg, Germany). Living cells were also counted with the trypan blue dye exclusion method. When a dose-dependent activity was observed, $\mathrm{IC}_{50}$ values were calculated using Graphpad PRISM 7 software ( $n=3$ in triplicate). Data were collected from at least three independent experiments and the values reported are means \pm standard errors of the mean (SEM).

MCF-7, HT-29, HeLa, and L929 cells $\left(3 \times 10^{5}\right.$ cells $\left./ \mathrm{mL}\right)$ were plated in 96 -well plates and incubated in the presence of $\mathrm{CO}_{2}$ atmosphere $(5 \%)$ for $24 \mathrm{~h}$ at $37^{\circ} \mathrm{C}$. Then, compounds 15-17 and 43-47 with concentrations ranging from $100 \mathrm{nM}$ to $100 \mu \mathrm{M}$ were added and incubated at $37^{\circ} \mathrm{C}$ for $72 \mathrm{~h}$. Then, $25 \mu \mathrm{L}$ of MTT $(5 \mathrm{mg} / \mathrm{mL}$ in PBS) were added to each well and the plates were left for another $3 \mathrm{~h}$ in the incubator at $37^{\circ} \mathrm{C}$ and at the end of this period, the supernatant was aspirated. To perform the reading, $100 \mu \mathrm{L}$ of dimethylsulfoxide (DMSO) were added in each well for the dissolution of the formazan crystals. The amount of formazan was measured by reading the plate at $560 \mathrm{~nm}$ absorbance. The concentration leading to $50 \%$ inhibition of viability $\left(\mathrm{IC}_{50}\right)$ was calculated by regression analysis using GraphPad Prism 5.0. Each sample was tested in triplicate in two independent experiments. Doxorubicin was used as a positive control.

\subsubsection{Evaluation of Compounds' Cytotoxicity Using the In Vivo Galleria mellonella Model}

G. mellonella larvae were bred in the IICiMed laboratory at $30-32{ }^{\circ} \mathrm{C}$ in a mixture of flour, honey, oatmeal, glycerol, and pollen until 260 to $320 \mathrm{mg}$ ( $6^{\text {th }}$ developmental stage). Groups of 10 larvae were randomly selected for the experiments. Each larva was injected in the $4^{\text {th }}$ left pro-leg with $10 \mu \mathrm{L}$ of compounds or an equivalent volume of PBS/DMSO for the control group at a dose varying between 10 and $50 \mathrm{mg} / \mathrm{kg}$ using a $0.3 \mathrm{~mL}-30 \mathrm{G}$-Insulin syringe. Larvae were incubated in the dark at $37{ }^{\circ} \mathrm{C}$ and survival was evaluated daily for 7 days. Death was assessed by the lack of movement in response to stimulus, with or without discoloration. Percentage survival was plotted using GraphPad Prism and survival analyses were determined using the log-rank test and the Kaplan-Meier survival curves. Two independent experiments were performed.

\section{Conclusions}

In summary, our research efforts in the synthesis of a natural product-inspired chemotype, endowed with kinase inhibition properties, produced attractive and safe $1,3$-dihydroxydibenzo[ $b, d]$ furan derivatives. This study confirmed cercosporamide as a valuable starting point for medicinal chemistry investigations and the removal of chirality afforded a flat tricyclic core with very promising enzyme and cellular potencies. Indeed, it 
was well established that the dual Pim1/2-CLK kinases inhibition promoted very interesting antiproliferative properties against the AML cell line as confirmed by the growth inhibitory activity at a low micromolar concentration, coupled with the nanomolar $\mathrm{IC}_{50}$ values obtained against the enzymes, particularly for the most active compound 44 .

Docking studies demonstrated that the 4-carboxamide group of the dibenzofurans was not essential for binding within the ATP pocket of Pim-1, in contrast to the hydroxy groups. In future, the replacement of the carboxamide group will be investigated to validate the hypothesis, and taking into account the level of activity of usnic acid towards Pim1/2, its substitution pattern could also serve as model for further design. In parallel, the very encouraging results obtained for this synthetic compound library deserve further optimization for complete SAR studies.

Supplementary Materials: Spectroscopic data $\left({ }^{1} \mathrm{H}\right.$ and ${ }^{13} \mathrm{C}$ NMR spectra) for all the compounds.

Author Contributions: Conceptualization, P.M., I.O.-G. and M.-A.B.; methodology, P.M., I.O.-G., M.-A.B. and C.L.; investigation, V.H.D., J.T., P.M., I.O.-G., M.-A.B., C.L., S.B., B.B., T.R., T.G.d.S., C.D.-S., F.G. and M.B.-B.; analysis, F.O.M.; writing-original draft preparation, P.M., V.H.D. and C.L.; writing-review and editing, P.M., I.O.-G., F.O.M.; supervision, P.M., I.O.-G. and M.-A.B.; project administration, P.M., I.O.-G.; funding acquisition, P.M. All authors have read and agreed to the published version of the manuscript.

Funding: This research was funded by a PhD grant from "Campus France Projet 911 Vietnam" and part of the work was also realized in the frame of the French and Irish Programme "PHC Ulysses" thanks to Campus France and the Irish Research Council (IRC). The authors thank the School of Pharmacy-University of Nantes, France and the College of Medecine and Pharmacy-University of Phu Tho, Vietnam for the cooperation agreement.

Institutional Review Board Statement: Not applicable.

Informed Consent Statement: Not applicable.

Data Availability Statement: Not applicable.

Acknowledgments: The authors thank the Cancéropôle Grand Ouest (3MC network-Marine Molecules, Metabolism and Cancer), GIS IBiSA (Infrastructures en Biologie Santé et Agronomie) and Biogenouest (Western France life science and environment core facility network) for supporting the KISSf screening facility.

Conflicts of Interest: The authors declare no conflict of interest. The funders had no role in the design of the study; in the collection, analyses, or interpretation of data; in the writing of the manuscript, or in the decision to publish the results.

Sample Availability: Samples of the compounds are available from the authors.

\section{References}

1. Sugawara, F.; Strobel, S.; Strobel, G.; Larsen, R.D.; Berglund, D.L.; Gray, G.; Takahashi, N.; Coval, S.J.; Stout, T.J.; Clardy, J. The structure and biological activity of cercosporamide from Cercosporidium henningsii. J. Org. Chem. 1991, 56, 909-910. [CrossRef]

2. Hoffman, A.M.; Mayer, S.G.; Strobel, G.A.; Hess, W.M.; Sovocool, G.W.; Grange, A.H.; Harper, J.K.; Arif, A.M.; Grant, D.M.; Kelley-Swift, E.G. Purification, identification and activity of phomodione, a furandione from an endophytic Phoma species. Phytochemistry 2008, 69, 1049-1056. [CrossRef] [PubMed]

3. Wang, L.-W.; Xu, B.-G.; Wang, J.-Y.; Su, Z.-Z.; Lin, F.-C.; Zhang, C.-L.; Kubicek, C.P. Bioactive metabolites from Phoma species, an endophytic fungus from the Chinese medicinal plant Arisaema Erubescens. Appl. Microbiol. Biotechnol. 2012, 93, $1231-1239$. [CrossRef]

4. Hosoya, T.; Ohsumi, J.; Hamano, K.; Ono, Y.; Miura, M. Method for Producing Cercosporamide. U.S. Patent 2010/0152467, 2010.

5. Sussman, A.; Huss, K.; Chio, L.-C.; Heidler, S.; Shaw, M.; Ma, D.; Zhu, G.; Campbell, R.M.; Park, T.-S.; Kulanthaivel, P.; et al. Discovery of cercosporamide, a known antifungal natural product, as a selective Pkc1 kinase inhibitor through high-through put screening. Eukaryot. Cell 2004, 3, 932-943. [CrossRef]

6. LaFayette, S.L.; Collins, C.; Zaas, A.K.; Schell, W.A.; Betancourt-Quiroz, M.; Gunatilaka, A.A.L.; Perfect, J.R.; Cowen, L.E. PKC signaling regulates drug resistance of the fungal pathogen Candida albicans via circuitry comprised of Mkc1, calcineurin, and Hsp90. PLoS Pathog. 2010, 6, e1001069. [CrossRef] [PubMed] 
7. Konicek, B.W.; Stephens, J.R.; McNulty, A.M.; Robichaud, N.; Peery, R.B.; Dumstorf, C.A.; Dowless, M.S.; Iversen, P.W.; Parsons, S.; Ellis, K.E.; et al. Therapeutic inhibition of MAP kinase interacting kinase blocks eukaryotic initiation factor 4E phosphorylation and suppresses outgrowth of experimental lung metastases. Cancer Res. 2011, 71, 1849-1857. [CrossRef]

8. Hou, J.; Lam, F.; Proud, C.; Wang, S. Targeting Mnks for cancer therapy. Oncotarget 2012, 3, 118-131. [CrossRef]

9. Altman, J.K.; Szilard, A.; Konicek, B.W.; Iversen, P.W.; Kroczynska, B.; Glaser, H.; Sassano, A.; Vakana, E.; Graff, J.R.; Platanias, L.C. Inhibition of Mnk kinase activity by cercosporamide and suppressive effects on acute myeloid leukemia precursors. Blood 2013, 121, 3675-3681. [CrossRef]

10. Liu, Y.; Sun, L.; Su, X.; Guo, S. Inhibition of eukaryotic initiation factor 4E phosphorylation by cercosporamide selectively suppresses angiogenesis, growth and survival of human hepatocellular carcinoma. Biomed. Pharmacother. 2016, 84, 237-243. [CrossRef]

11. Grzmil, M.; Seebacher, J.; Hess, D.; Behe, M.; Schibli, R.; Moncayo, G.; Frank, S.; Hemmings, B.A. Inhibition of MNK pathways enhances cancer cell response to chemotherapy with temozolomide and targeted radionuclide therapy. Cell. Signal. 2016, 28, 1412-1421. [CrossRef]

12. Hoeksma, J.; van der Zon, G.C.M.; ten Dijke, P.; den Hertog, J. Cercosporamide inhibits bone morphogenetic protein receptor type I kinase activity in zebrafish. Dis. Model. Mech. 2020, 13, dmm045971. [CrossRef] [PubMed]

13. Furukawa, A.; Arita, T.; Satoh, S.; Araki, K.; Kuroha, M.; Ohsumi, J. (-)-Cercosporamide derivatives as novel antihyperglycemic agents. Bioorg. Med. Chem. Lett. 2009, 19, 724-726. [CrossRef] [PubMed]

14. Furukawa, A.; Arita, T.; Satoh, S.; Wakabayashi, K.; Hayashi, S.; Matsui, Y.; Araki, K.; Kuroha, M.; Ohsumi, J. Discovery of a novel selective PPAR $\gamma$ modulator from (-)-cercosporamide derivatives. Bioorg. Med. Chem. Lett. 2010, 20, 2095-2098. [CrossRef]

15. Bazin, M.-A.; Bodero, L.; Tomasoni, C.; Rousseau, B.; Roussakis, C.; Marchand, P. Synthesis and antiproliferative activity of benzofuran-based analogs of cercosporamide against non-small cell lung cancer cell lines. Eur. J. Med. Chem. 2013, 69, 823-832. [CrossRef]

16. Dao, V.H.; Ourliac-Garnier, I.; Bazin, M.-A.; Jacquot, C.; Baratte, B.; Ruchaud, S.; Bach, S.; Grovel, O.; Le Pape, P.; Marchand, P. Benzofuro [3,2-d] pyrimidines inspired from cercosporamide CaPkc1 inhibitor: Synthesis and evaluation of fluconazole susceptibility restoration. Bioorg. Med. Chem. Lett. 2018, 28, 2250-2255. [CrossRef] [PubMed]

17. Antoine, M.; Schuster, T.; Seipelt, I.; Aicher, B.; Teifel, M.; Günther, E.; Gerlach, M.; Marchand, P. Efficient synthesis of novel disubstituted pyrido[3,4-b]pyrazines for the design of protein kinase inhibitors. Med. Chem. Commun. 2016, 7, 224-229. [CrossRef]

18. Winfield, H.J.; Cahill, M.M.; O'Shea, K.D.; Pierce, L.T.; Robert, T.; Ruchaud, S.; Bach, S.; Marchand, P.; McCarthy, F.O. Synthesis and anticancer activity of novel bisindolylhydroxymaleimide derivatives with potent GSK-3 kinase inhibition. Bioorg. Med. Chem. 2018, 26, 4209-4224. [CrossRef]

19. Oyallon, B.; Brachet-Botineau, M.; Logé, C.; Bonnet, P.; Souab, M.; Robert, T.; Ruchaud, S.; Bach, S.; Berthelot, P.; Gouilleux, F.; et al. Structure-based design of novel quinoxaline-2-carboxylic acids and analogues as Pim-1 inhibitors. Eur. J. Med. Chem. 2018, 154, 101-109. [CrossRef]

20. Loidreau, Y.; Dubouilh-Benard, C.; Nourrisson, M.-R.; Loaëc, N.; Meijer, L.; Besson, T.; Marchand, P. Exploring kinase inhibition properties of 9H-pyrimido[5,4-b]- and [4,5-b]indol-4-amine derivatives. Pharmaceuticals 2020, 13, 89. [CrossRef]

21. Oyallon, B.; Brachet-Botineau, M.; Logé, C.; Robert, T.; Bach, S.; Ibrahim, S.; Raoul, W.; Croix, C.; Berthelot, P.; Guillon, J.; et al. New quinoxaline derivatives as dual Pim-1/2 kinase inhibitors: Design, synthesis and biological evaluation. Molecules 2021, 26, 867. [CrossRef]

22. Bazin, M.-A.; Cojean, S.; Pagniez, F.; Bernadat, G.; Cavé, C.; Ourliac-Garnier, I.; Nourrisson, M.-R.; Morgado, C.; Picot, C.; Leclercq, O.; et al. In vitro identification of imidazo[1,2-a]pyrazine-based antileishmanial agents and evaluation of L. major casein kinase 1 inhibition. Eur. J. Med. Chem. 2021, 210, 112956. [CrossRef]

23. Love, B.E. Isolation and synthesis of polyoxygenated dibenzofurans possessing biological activity. Eur. J. Med. Chem. 2015, 97, 377-387. [CrossRef]

24. Oramas-Royo, S.; Pantoja, K.D.; Amesty, Á.; Romero, C.; Lorenzo-Castrillejo, I.; Machín, F.; Estévez-Braun, A. Synthesis and antibacterial activity of new symmetric polyoxygenated dibenzofurans. Eur. J. Med. Chem. 2017, 141, 178-187. [CrossRef]

25. Heng, S.; Harris, K.M.; Kantrowitz, E.R. Designing inhibitors against fructose 1,6-bisphosphatase: Exploring natural products for novel inhibitor scaffolds. Eur. J. Med. Chem. 2010, 45, 1478-1484. [CrossRef]

26. Millot, M.; Dieu, A.; Tomasi, S. Dibenzofurans and derivatives from lichens and ascomycetes. Nat. Prod. Rep. 2016, 33, 801-811. [CrossRef] [PubMed]

27. Fan, Y.; Huang, M.; Cao, Y.; Gong, P.; Liu, W.; Jin, S.; Wen, J.; Jing, Y.; Liu, D.; Zhao, L. Usnic acid is a novel Pim-1 inhibitor with the abilities of inhibiting growth and inducing apoptosis in human myeloid leukemia cells. RSC Adv. 2016, 6, 24091-24096. [CrossRef]

28. Wang, S.; Zang, J.; Huang, M.; Guan, L.; Xing, K.; Zhang, J.; Liu, D.; Zhao, L. Discovery of novel (+)-usnic acid derivatives as potential anti-leukemia agents with pan-pim kinases inhibitory activity. Bioorg. Chem. 2019, 89, 102971. [CrossRef]

29. Asati, V.; Mahapatra, D.K.; Bharti, S.K. PIM kinase inhibitors: Structural and pharmacological perspectives. Eur. J. Med. Chem. 2019, 172, 95-108. [CrossRef] [PubMed]

30. Alnabulsi, S.; Al-Hurani, E.A. Pim kinase inhibitors in cancer: Medicinal chemistry insights into their activity and selectivity. Drug Discov. Today 2020, 25, 2062-2069. [CrossRef]

31. Arrouchi, H.; Lakhlili, W.; Ibrahimi, A. A review on PIM kinases in tumors. Bioinformation 2019, 15, 40-45. [CrossRef] [PubMed] 
32. Tursynbay, Y.; Zhang, J.; Li, Z.; Tokay, T.; Zhumadilov, Z.; Wu, D.; Xie, Y. Pim-1 kinase as cancer drug target: An update. Biomed. Rep. 2016, 4, 140-146. [CrossRef] [PubMed]

33. Panchal, N.K.; Sabina, E.P. A serine/threonine protein PIM kinase as a biomarker of cancer and a target for anti-tumor therapy. Life Sci. 2020, 255, 117866. [CrossRef]

34. Harshita, P.S.; Yasaswi, P.S.; Jyothi, V.; Jyostna, T.S. Pim-1 kinase: A novel target for cancer chemotherapy-A review. IJPSR 2020, 11, 2528-2538. [CrossRef]

35. Wang, Y.; Xiu, J.; Ren, C.; Yu, Z. Protein kinase PIM2: A simple PIM family kinase with complex functions in cancer metabolism and therapeutics. J. Cancer 2021, 12, 2570-2581. [CrossRef]

36. Sawaguchi, Y.; Yamazaki, R.; Nishiyama, Y.; Mae, M.; Abe, A.; Nishiyama, H.; Nishisaka, F.; Ibuki, T.; Sasai, T.; Matsuzaki, T. Novel pan-pim kinase inhibitors with imidazopyridazine and thiazolidinedione structure exert potent antitumor activities. Front. Pharmacol. 2021, 12, 672536. [CrossRef]

37. Du, Z.; Zhou, J.; Si, C.; Ma, W. Synthesis of dibenzofurans by palladium-catalysed tandem denitrification/C-H activation. Synlett 2011, 2011, 3023-3025. [CrossRef]

38. Panda, N.; Mattan, I.; Nayak, D.K. Synthesis of dibenzofurans via C-H activation of $o$-iodo diaryl ethers. J. Org. Chem. 2015, 80, 6590-6597. [CrossRef] [PubMed]

39. Zhao, H.; Yang, K.; Zheng, H.; Ding, R.; Yin, F.; Wang, N.; Li, Y.; Cheng, B.; Wang, H.; Zhai, H. A one-pot synthesis of dibenzofurans from 6-diazo-2-cyclohexenones. Org. Lett. 2015, 17, 5744-5747. [CrossRef]

40. Cho, J.Y.; Roh, G.; Cho, E.J. Visible-light-promoted synthesis of dibenzofuran derivatives. J. Org. Chem. 2018, 83, 805-811. [CrossRef] [PubMed]

41. Camargo Solórzano, P.; Brigante, F.; Pierini, A.B.; Jimenez, L.B. Photoinduced synthesis of dibenzofurans: Intramolecular and intermolecular comparative methodologies. J. Org. Chem. 2018, 83, 7867-7877. [CrossRef]

42. Wassmundt, F.W.; Pedemonte, R.P. An improved synthesis of dibenzofurans by a free-radical cyclization. J. Org. Chem. 1995, 60, 4991-4994. [CrossRef]

43. Gajera, J.M.; Gopalan, B.; Yadav, P.S.; Patil, S.D.; Gharat, L.A. Synthesis of multi-substituted dibenzo[b,d]furan. J. Heterocycl. Chem. 2008, 45, 797-801. [CrossRef]

44. Fang, L.; Fang, X.; Gou, S.; Lupp, A.; Lenhardt, I.; Sun, Y.; Huang, Z.; Chen, Y.; Zhang, Y.; Fleck, C. Design, synthesis and biological evaluation of d-ring opened galantamine analogs as multifunctional anti-Alzheimer agents. Eur. J. Med. Chem. 2014, 76, 376-386. [CrossRef] [PubMed]

45. Sambiagio, C.; Marsden, S.P.; Blacker, A.J.; McGowan, P.C. Copper catalysed ullmann type chemistry: From mechanistic aspects to modern development. Chem. Soc. Rev. 2014, 43, 3525-3550. [CrossRef]

46. Brewster, R.Q.; Groening, T. p-nitrodiphenyl ether: Ether, p-nitrophenyl phenyl. In Organic Syntheses; John Wiley \& Sons, Inc.: Hoboken, NJ, USA, 2003; Volume 14, p. 66. ISBN 978-0-471-26422-4.

47. Kelly, S.M.; Lipshutz, B.H. Chemoselective reductions of nitroaromatics in water at room temperature. Org. Lett. 2014, 16, 98-101. [CrossRef]

48. Krug, M.; Wichapong, K.; Erlenkamp, G.; Sippl, W.; Schächtele, C.; Totzke, F.; Hilgeroth, A. Discovery of 4-benzylaminosubstituted $\alpha$-carbolines as a novel class of receptor tyrosine kinase inhibitors. ChemMedChem 2011, 6, 63-72. [CrossRef]

49. Liégault, B.; Lee, D.; Huestis, M.P.; Stuart, D.R.; Fagnou, K. Intramolecular Pd(II)-catalyzed oxidative biaryl synthesis under air: Reaction development and scope. J. Org. Chem. 2008, 73, 5022-5028. [CrossRef] [PubMed]

50. Bartholomäus, R.; Dommershausen, F.; Thiele, M.; Karanjule, N.S.; Harms, K.; Koert, U. Total synthesis of the postulated structure of fulicineroside. Chem. Eur. J. 2013, 19, 7423-7436. [CrossRef] [PubMed]

51. Wang, S.; Li, B.; Liu, B.; Huang, M.; Li, D.; Guan, L.; Zang, J.; Liu, D.; Zhao, L. Design and synthesis of novel 6-hydroxy-4methoxy-3-methylbenzofuran-7-carboxamide derivatives as potent mnks inhibitors by fragment-based drug design. Bioorg. Med. Chem. 2018, 26, 4602-4614. [CrossRef]

52. Jepsen, T.H.; Donor, D.-F. Synthesis of dibenzothiophene, dibenzofuran and carbazole donor-acceptor chromophores. Synthesis 2013, 45, 1115-1120. [CrossRef]

53. Boyer, J.L.; Krum, J.E.; Myers, M.C.; Fazal, A.N.; Wigal, C.T. Synthetic utility and mechanistic implications of the fries rearrangement of hydroquinone diesters in boron trifluoride complexes. J. Org. Chem. 2000, 65, 4712-4714. [CrossRef]

54. Liu, L.-X.; Wang, X.-Q.; Yan, J.-M.; Li, Y.; Sun, C.-J.; Chen, W.; Zhou, B.; Zhang, H.-B.; Yang, X.-D. Synthesis and antitumor activities of novel dibenzo[b,d]furan-imidazole hybrid compounds. Eur. J. Med. Chem. 2013, 66, 423-437. [CrossRef] [PubMed]

55. Liu, J.; Fitzgerald, A.E.; Mani, N.S. Facile assembly of fused benzo[4,5]furo heterocycles. J. Org. Chem. 2008, 73, 2951-2954. [CrossRef]

56. Zegzouti, H.; Zdanovskaia, M.; Hsiao, K.; Goueli, S.A. ADP-Glo: A bioluminescent and homogeneous ADP monitoring assay for kinases. ASSAY Drug Dev. Technol. 2009, 7, 560-572. [CrossRef] [PubMed]

57. Lindberg, M.F.; Meijer, L. Dual-specificity, tyrosine phosphorylation-regulated kinases (DYRKs) and Cdc2-like kinases (CLKs) in human disease, an overview. Int. J. Mol. Sci. 2021, 22, 6047. [CrossRef]

58. Dinh, H.; Semenec, L.; Kumar, S.S.; Short, F.L.; Cain, A.K. Microbiology's next top model: Galleria in the molecular age. Pathog. Dis. 2021, 79, ftab006. [CrossRef] 
59. Bennett, C.J.; Caldwell, S.T.; McPhail, D.B.; Morrice, P.C.; Duthie, G.G.; Hartley, R.C. Potential therapeutic antioxidants that combine the radical scavenging ability of myricetin and the lipophilic chain of vitamin $\mathrm{E}$ to effectively inhibit microsomal lipid peroxidation. Bioorg. Med. Chem. 2004, 12, 2079-2098. [CrossRef]

60. Chen, F.C.; Chang, T. Synthesis of 7-halogenoflavone and related compounds. J. Chem. Soc. 1958, 146-150. [CrossRef]

61. Jin, X.; Davies, R.P. Copper-catalysed aromatic-finkelstein reactions with amine-based ligand systems. Catal. Sci. Technol. 2017, 7, 2110-2117. [CrossRef]

62. Tripos Associates, Inc. SYBYL-X 1.3; Tripos Associates, Inc.: St. Louis, MO, USA, 2013.

63. Clark, M.; Cramer, R.D.; Van Opdenbosch, N. Validation of the general purpose tripos 5.2 force field. J. Comput. Chem. 1989, 10, 982-1012. [CrossRef]

64. Morishita, D.; Takami, M.; Yoshikawa, S.; Katayama, R.; Sato, S.; Kukimoto-Niino, M.; Umehara, T.; Shirouzu, M.; Sekimizu, K.; Yokoyama, S.; et al. Cell-permeable carboxyl-terminal P27Kip1 peptide exhibits anti-tumor activity by inhibiting Pim-1 kinase. J. Biol. Chem. 2011, 286, 2681-2688. [CrossRef] [PubMed]

65. Jones, G.; Willett, P.; Glen, R.C.; Leach, A.R.; Taylor, R. Development and validation of a genetic algorithm for flexible docking. J. Mol. Biol. 1997, 267, 727-748. [CrossRef] [PubMed]

66. Dassault Systèmes. Dassault Systèmes BIOVIA, Discovery Studio Visualizer, v19.1.0.18287; Dassault Systèmes: San Diego, CA, USA, 2019. 